\title{
NUTRIÇÃO MINERAL E DESENVOLVIMENTO DE CULTIVARES DE ARROZ (Oryza sativa L.), CULTIVADOS EM SOLUÇÕES NUTRITIVAS COM DIFERENTES CONCENTRAÇÕES DE FERRO
}

\section{RAMON MARCELO MAYOL}

Engenheiro Agrônomo

Orientador: Prof. Dr. Antonio Roque Dechen

Dissertação apresentada à Escola Superior de Agricultura "Luiz de Queiroz", da Universidade de São Paulo, para obtenção do título de Mestre em Ciências, Área de concentração: Fisiología e Bioquímica de Plantas.

P I R A C I C A B A

Estado de São Paulo - Brasil

Março - 1996 
Dados Internacionais de Catalogação na Publicação (CIP)

DIVISÃo DE BIBLIOTECA E DOCUMENTAÇĀ́O - Campus "Luiz de Queiroz"/USP

Mayol, Ramon Marcelo

Nutrição mineral e desenvolvimento de cultivares de arroz (Oryza sativa L.),

Marcelo Mayol. - - Piracicaba, 1996.

114p. : il.

Dissertação (mestrado ) - - Escola Superior de Agricultura Luiz de Queiroz, 1996.

Bibliografia.

1. Arroz - Nutrição 2. Ferro em arroz - Efeito I. Título

CDD $\quad 633.18$ 
NUTRIÇÃO MINERAL E DESENVOLVIMENTO DE CULTIVARES DE ARROZ (Oryza sativa L.), CULTIVADOS EM SOLUÇÕES NUTRITIVAS COM DIFERENTES CONCENTRAÇÕES DE FERRO

RAMON MARCELO MAYOL

Aprovada em: 06.05.1996

Comissão julgadora:

Prof.Dr. ANTONIO ROQUE DECHEN

ESALQ/USP

Dr. PEDRO ROBERTO FURLANI

IAC

Prof.Dr. ANTONIO AUGUSTO LUCCHESI

ESALQ/USP

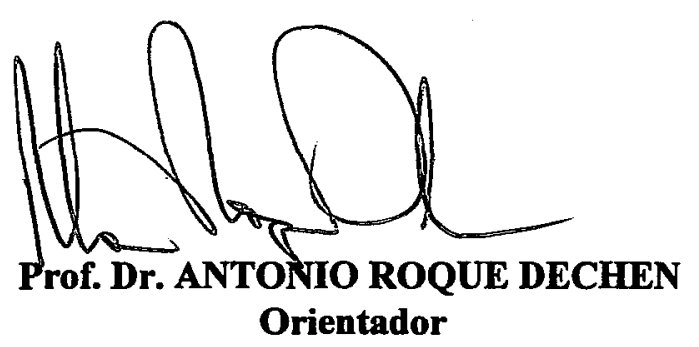


A meu pai "in memoriam"

A minha mãe,

\section{OFEREÇO}

A minha esposa MARIA MARTHA

e a nossa filha ANA PAULA,

DEDICO. 


\section{AGRADECIMENTOS}

Ao Prof. Dr. Antônio Roque Dechen, pela orientação, amizade, incentivo, profissionalismo e pela forma precisa e objetiva com que me orientou;

Aos Professores do Setor de Nutrição Mineral de Plantas do Departamento de Química da ESALQ, Dr. Quirino Augusto de Camargo Carmello e Dr. Francisco Antônio Monteiro, pelas sugestões e apoio na condução dos experimentos;

Ao Dr. Pedro Roberto Furlani, pesquisador científico do Instituto Agronômico de Campinas, pelas sugestões e colaboração para a execução deste trabalho;

Ao Dr. José Guilherme de Freitas, pesquisador científico do Instituto Agronômico de Campinas, pela colaboração nas leituras de clorofila;

Ao Professor Gabriel Adrián Sarriés pelo auxílio na interpretação dos resultados das análises estatísticas;

Aos funcionários do Laboratório de Nutrição Mineral de Plantas, ESALQ, Lúcia Helena S. Pavan Forti, Lourdes Aparecida Dario Gonzalez, Fernando Eder Ré, Mirtes Ventura Sesso, Edinéia Cristina Scervino Mondoni, Nivanda Maria de Moura, Sueli Maria Amaral Campos Bovi, pelo auxílio na realização das análises químicas;

A Bibliotecária Kátia Maria de Andrade Ferraz, pelo auxílio na correção das referências bibliográficas; 
As técnicas especializadas do Laboratório de sementes, Ana Dionisia Luz Novembre e Helena Maria Pescarin Chamma, pela colaboração na realização da germinação das sementes de arroz;

Aos professores e funcionários da ESALQ pela indispensável colaboração, amizade e colegismo, durante o período de realização do curso;

Ao Instituto Nacional de Tecnología Agropecuaria (INTA), e em especial a E.E.A. Cerro Azul e Centro Regional Misiones, pela oportunidade proporcionada para a realização deste curso;

Ao Curso de Pós-Graduação em Fisiología e Bioquímica de Plantas da ESALQ-USP, pela possibilidade de treinamento;

À todos os professores do curso de Fisiología Vegetal e Bioquímica de Plantas pela dedicação e conhecimentos transmitidos;

A Conselho Nacional de Desenvolvimento Científico pela concessão da bolsa de estudos, para realização deste trabalho;

Aos colegas e amigos estudantes da Pós-Graduação do setor de Nutrição Mineral de Plantas, pela amizade e colegismo, durante a realização do curso. 


\section{SUMÁRIO}

Página

RESUMO ................................................................................... viii

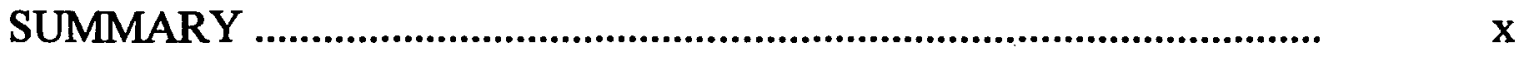

1. INTRODUÇÃO

2. REVISÃO DE LITERATURA

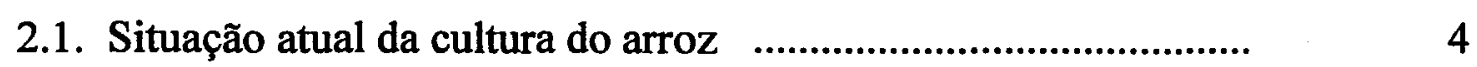

2.1.1. Arroz no mundo ........................................................ 4

2.1.2. Arroz no Brasil .................................................... 5

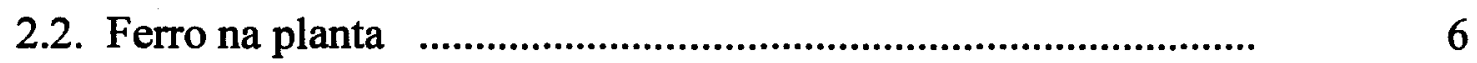

2.2.1. Considerações gerais do micronutriente ferro ............... 6

2.2.2. Concentração, deficiência e toxicidade ....................... 7

2.2.3. Ferro e características fisiológicas $\quad$.............................. 11

2.2.4. Ferro e clorofila ............................................................ 17

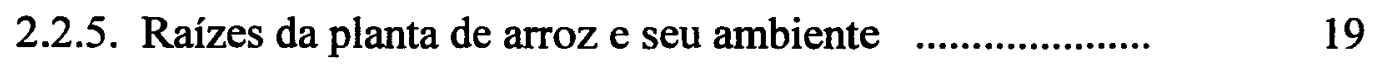

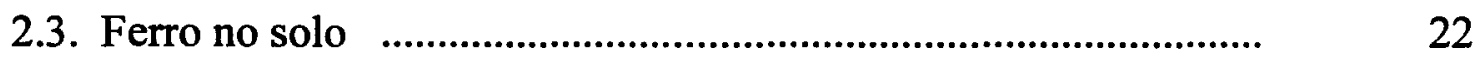

2.3.1. Níveis de ocorrência e formas .................................... 22

2.3.2. Disponibilidade ..................................................... 24

2.4. Algumas prácticas para reduzir toxidez de ferro $\quad$...................... 27

3. MATERIAL E MÉTODOS

3.1. Características dos genótipos............................................. 30

3.3. Obtenção de plântulas .........................................................

3.4. Instalação e transplante $\quad$.......................................................... 32

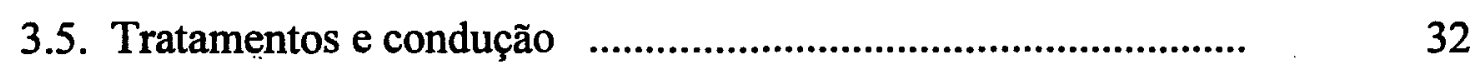


3.6. Colheita e preparo do material ….................................................... 35

3.7. Características avaliadas ............................................................ 37

3.8. Delineamento Experimental e Estatística ..................................... 38

4. RESULTADOS E DISCUSSÃO ….................................................... 39

4.1. Aspecto das plantas dos genótipos estudados ................................ 39

4.2. Efeito dos níveis de ferro sobre alguns parâmetros de crescimento do arroz

4.2.1. Efeito sobre a produção de matéria seca ............................ 41

4.2.2. Efeito sobre a área foliar ............................................... $\quad 45$

4.2.3. Efeito sobre a altura de planta e comprimento das raízes ... 48

4.2.4 Efeito sobre o número de perfilhos .................................... 51

4.3. Efeito dos níveis de ferro sobre o teor de clorofila em plantas de arroz.

4.4. Efeito dos níveis de ferro na solução nutritiva sobre a concentração de macronutrientes em arroz.

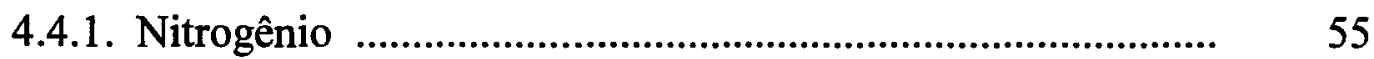

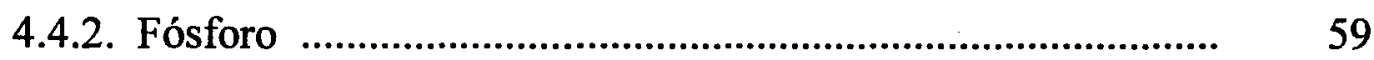

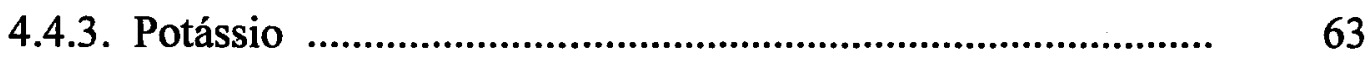

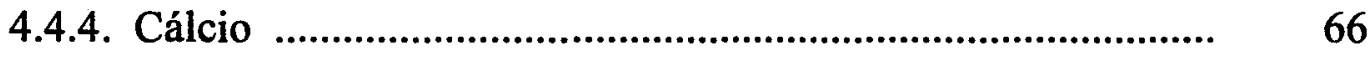

4.4.5. Magnésio ............................................................................ 70

4.5. Efeito dos níveis de ferro na solução nutritiva sobre a concentração de micronutrientes em dois genótipos de arroz ................................ 73

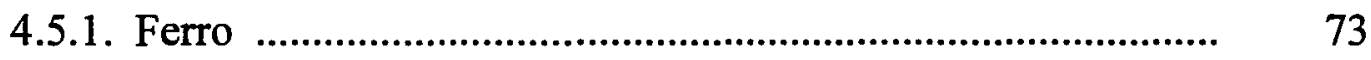

4.5.2. Manganés ……........................................................... 78

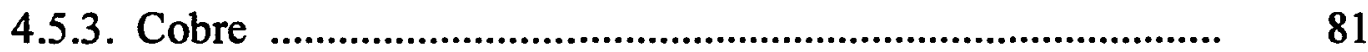

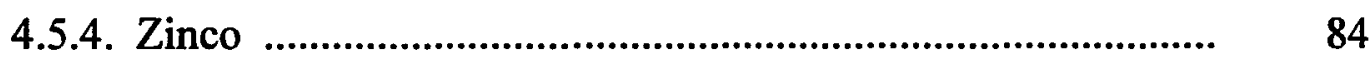


vii

Página

4.6. Efeito dos níveis de ferro sobre o pH da solução nutritiva, em dois genótipos de arroz 


\title{
NUTRIÇĀO MINERAL E DESENVOLVIMENTO DE CULTIVARES DE ARROZ (Oryza sativa L.), CULTIVADOS EM SOLUÇÕES NUTRITIVAS COM DIFERENTES CONCENTRAÇÕES DE FERRO
}

\author{
Autor: Ramon Marcelo Mayol \\ Orientador: Prof. Dr. Antonio Roque Dechen
}

\section{RESUMO}

O presente experimento foi conduzido em câmara de crescimento, com o objetivo de avaliar os efeitos de níveis de ferro em solução nutritiva, sobre o desenvolvimento de dois genótipos de arroz IAC-47 e IAC-1205, estudando os efeitos quanto a aspectos nutricionais e fisiológicos. Foram utilizadas concentrações de ferro de 0,$125 ; 0,625 ; 1,25 ; 12,50 ; 25,00$ e $50,00 \mathrm{mg} \mathrm{L}^{-1}$, utilizando-se o delineamento de blocos ao acaso com arranjo fatorial, 6 x 4 com 4 repetições. $\mathrm{O}$ experimento foi conduzido em condições ambientais controladas com ciclos de iluminação de 16 horas de luz e 8 horas de escuro, umidade do ambiente de aproximadamente $60 \%$, com temperatura média de $25^{\circ} \mathrm{Celsius.} \mathrm{As}$ plantas foram colhidas 30 dias após sua instalação, fracionando em parte aérea e raízes, que posteriormente seco o material em estufa a $60^{\circ}-70^{\circ} \mathrm{C}$ até peso constante, foi moído para análise química.

Os resultados obtidos permitem concluir que doses elevadas de ferro (25 e $50 \mathrm{mg} \mathrm{L}^{-1}$ ) foram prejudiciais aos dois genótipos estudados, os quais apresentaram sintomas típicos de toxidez de ferro com redução da produção de 

matéria seca da parte aérea e das raízes dos genótipos, afetando também altura da planta, comprimento da raiz, número de perfilhos e área foliar. O genótipo IAC1205 foi menos prejudicado, mostrando-se mais tolerante a doses elevadas de ferro na solução nutritiva, provocado provavelmente por uma menor absorção e translocação de ferro das soluções, apresentando menores concentrações deste nutriente na parte aérea e nas raízes. Os teores de clorofila aumentaram nos dois genótipos em função do aumento de ferro nas soluções nutritivas. A concentração dos nutrientes analisados na matéria seca da parte aérea e raízes, em geral diminuíram nas maiores doses de ferro na solução nutritiva (25 e $50 \mathrm{mg} \mathrm{L}^{-1}$ ). Estes resultados demonstram que os genótipos de arroz diferem em tolerância à toxidez de ferro, para as condições deste experimento. 


\title{
MINERAL NUTRITION AND GROWTH OF RICE CULTIVARS (Oryza sativa L.), GROWN IN NUTRIENT SOLUTIONS WITH DIFFERENT IRON CONCENTRATIONS
}

\author{
Author: Ramon Marcelo Mayol \\ Adviser: Prof. Dr. Antonio Roque Dechen
}

\section{SUMMARY}

This experiment was carried out in growth chamber with the objective of evaluate the effect of six levels of iron in nutrient solution $(0,125$; 0,$625 ; 1,25 ; 12,50 ; 25,00$ e $50,00 \mathrm{mg} \mathrm{L}^{-1}$ ) on the growth of two rice genotypes IAC-47 and IAC-1205. A $6 \times 4$ factorial with four replications in completely randomized block design was used. The experiment was conducted in controlled conditions with light/dark regime of $16 / 8 \mathrm{~h}$, a relative humidity about $60 \%$, and an average temperature of $25^{\circ}$ Celsius. Plants were harvested at 30 days after starting the use of complete nutrient solution and were separated in shoot and roots. They were dried at $60^{\circ}-70^{\circ} \mathrm{C}$ to constant weight and then milled, and prepared for chemical analysis.

The results indicated that the genotypes were negatively affected by increasing concentrations of iron up to $12,5 \mathrm{mg} \mathrm{L}^{-1}$ in the nutrient solution. Plants of both genotypes showed typical iron toxicity symptoms which varied with the degree of tolerance of genotype. These plants had reduction in dry matter yield of shoot and roots, and reduction in height, root length, leaf area, number of tillers. 
The genotype IAC-1205 seemed to be more tolerante to the high level of iron in the nutrient solution, and this was associated with a lower iron uptake than the other genotype with lower concentrations of iron in shoot and roots. The chlorophyll content was directly related to the iron levels in nutrient solution.

In general, higher iron concentration in the growth medium (up to $12,5 \mathrm{mg} \mathrm{L}^{-1}$ ) promoted a decrease in the mineral concentrations in the shoot and roots of the plants. Iron concentrations in shoot and roots increased as the iron levels in the growth medium was increased. These results showed that rice genotypes differ in their tolerance to iron toxicity. 


\section{INTRODUÇÃO}

O arroz (Oryza sativa L.) é considerado uma das culturas mais importantes em termos de alimento básico à população humana representando também a base da economia em inúmeros países do mundo, encontrando-se amplamente distribuído em regiões tropicais, subtropicais e temperadas de todos os continentes. Trata-se de uma espécie que é cultivada em condições de sequeiro, várzea úmida e irrigado.

Atualmente, a produção mundial de arroz é de 518 milhões de toneladas, ocupando uma área de aproximadamente 150 milhões de hectares. China e Índia possuem em torno de $50 \%$ da área plantada com arroz no mundo, cuja produção representa $56 \%$ da produção mundial. América do Sul encontra-se em segundo lugar em produção, sendo o Brasil o primeiro produtor com 10,3 milhões de toneladas, ocupando o oitavo lugar na produção mundial. A produtividade varia de 2,0 $\mathrm{tha}^{-1}$ na África para $8,0 \mathrm{tha}^{-1}$ na Australia, sendo de 2,7 $\mathrm{t} \mathrm{ha}^{-1}$ na América do Sul, situando-se o Brasil em nono lugar com $2,3 \mathrm{t} \mathrm{ha}^{-1}$. (FAO - QUATERLY BULLETIN OF STATISTICS, 1994). 
A cultura de arroz, no Brasil ocupa uma área de aproximadamente 4,4 milhões de hectares, sendo cultivado em grande parte utilizando o sistema de cultivo sem irrigação, sistema encontrado no sudeste, centro-oeste e nordeste do país, com uma produtividade média em torno de $2 \mathrm{t} \mathrm{ha}^{-1}$, diferindo enormemente da obtida no sistema irrigado, que é da ordem de $5 \mathrm{t} \mathrm{ha}^{-1}$, encontrado em sua maioria nos estados de Rio Grande do Sul e Santa Catarina. O cultivo de arroz de sequeiro tem grande importância econômica e social no Brasil, contribuindo com cerca de $43 \%$ do total de arroz produzido no Pais. (FAO - QUATERLY BULLETIN OF STATISTICS, 1994).

A deficiência ou toxicidade de nutrientes no solo, frequentemente representa um sério problema a resolver para estabilizar ou incrementar a produção agrícola.

Os nutrientes minerais desempenham funções específicas e essenciais no metabolismo das plantas. $\mathrm{O}$ micronutriente Fe participa diretamente do desenvolvimento vegetal desempenhando em diferentes partes do metabolismo funções vitais no crescimento e processos metabólicos durante o ciclo das mesmas.

A cultura do arroz irrigado tem-se mostrado sensível à toxicidade de ferro, principalmente associado ao excesso de ferro solúvel na água, resultante de reações de oxi-redução decorrentes da inundação do solo, mais frequentemente naqueles fortemente ácidos. Vários são os países que apresentam problemas de toxidez de ferro, como Índia, Vietnam, Tailandia, Sri lanka, Malásia, Indonésia, Filipinas, Senegal, Libéria, Nigéria, China e Colômbia (Ottow et.al., 1983). No Brasil, os Estados do Pará, Minas Gerais, Rio de Janeiro, Goiás, Santa Catarina e Rio Grande do Sul, também apresentam problemas de toxidez de ferro, representando um fator limitante para o desenvolvimento das plantas de arroz irrigado. 
Altas concentrações de ferro (preferencialmente como $\mathrm{Fe}^{+2}$ na solução do solo) podem provocar redução de parâmetros de crescimento em plantas de arroz, tais como: altura de planta, número de perfilhos, comprimento de raiz, e peso de matéria seca da parte aérea e raizes, com grandes variações entre cultivares.

Por outro lado a deficiência de ferro em arroz de sequeiro, quando submetido a rotação com outras culturas em solos do cerrado, foi observada em vários Estados Brasileiros, devido principalmente à baixa disponibilidade ou absorção do elemento, como consequência da aplicação de calcário em grandes quantidades, sendo esta prática comum em solos do cerrado.

$\mathrm{O}$ presente trabalho teve como objetivo avaliar a influência de níveis de ferro em solução nutritiva, no desenvolvimento de genótipos de arroz, estudando os efeitos quanto a aspectos nutricionais e fisiológico nessa cultura. 


\section{REVISÃO DE LITERATURA}

2.1. Situação atual da cultura de arroz.

\subsubsection{Arroz no mundo}

$\mathrm{O}$ arroz, representa uma fonte primária na alimentação para mais de um terço da população mundial, sendo este cereal de grande importância para países em desenvolvimento, constituindo-se na base da dieta da população e principal produto da economia destes países. A produção mundial é pouco comercializada internacionalmente, apresentando esta cultura característica de subsistência.

Considerando os sistemas de cultivo, o irrigado é utilizado em mais de $50 \%$ da área cultivada com arroz no mundo, contribuindo com mais de $70 \%$ da produção mundial. Ao contrário, a área cultivada em sistema de sequeiro corresponde aproximadamente a $23 \%$, participando com $17 \%$ da produção. 
Representando o sistema de várzea úmida a porcentagem restante. (FAO QUATERLY BULLETIN OF STATISTICS, 1994)

\subsubsection{Arroz no Brasil}

O Brasil é o maior produtor de arroz da América Latina, dos quase 7 milhões de ha cultivados com arroz, aproximadamente 4,4 milhões são encontradas no Brasil. É cultivado em todos os Estados do Brasil, e conforme (ANUÁRIO ESTATÍSTICO DO BRASIL, 1993) o Estado do Rio Grande do Sul ocupa o primeiro lugar em área plantada, produção e rendimento médio.

Os dois sistemas predominantes de cultivo no Brasil estão representados por arroz irrigado e de sequeiro, o primeiro é encontrado em sua maioria nos estados de Rio Grande do Sul e Santa Catarina, o qual é caracterizado por lavouras extensas realizadas por produtores de maior capacidade de investimento, o de sequeiro muito superior em área quando comparado com o anterior, é praticado no sudeste, centro-oeste e nordeste do país, apresentando baixos níveis de produtividade; a diferença do irrigado, este sistema é caracterizado por ser praticado em áreas menores e em sua grande maioria por produtores de menor capacidade econômica.

Atualmente a área plantada com arroz no Estado de São Paulo é de aproximadamente $190 \mathrm{mil}$ ha, situando-se no oitavo lugar quando comparado com os outros Estados do Brasil, o mesmo participa com 3,4 \% da produção total

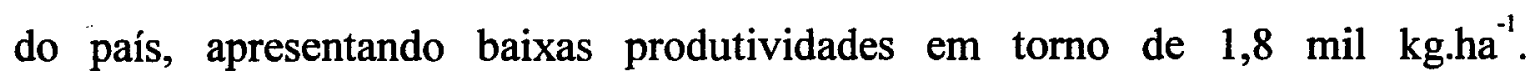
(ANUÁRIO ESTATÍSTICO DO BRASIL, 1993). Aproximadamente $10 \%$ da área total do Estado é plantada utilizando o sistema de arroz irrigado, sendo que na superficie restante é utilizado o sistema de sequeiro. 


\subsection{Ferro na planta}

\subsubsection{Considerações gerais}

O micronutriente Ferro é considerado um nutriente de significativa importância para transformações energéticas necessárias para sínteses e outros processos vitais das células. Segundo Menguel \& Kirkby (1987), é um importante componente em sistemas enzimáticos das plantas, tais como citocromos (contendo um complexo Fe-porfirina como grupo prostético) no transporte de eletron, o envolvimento do citocromo oxidase na cadeia terminal da respiração, possível participação no metabolismo de proteínas, componente da ferredoxina, importante a sua participação no processo da fotossíntese, e requerido para redução de nitrato e sulfato, assimilação de $\mathrm{N}_{2}$, e produção de energia (NADP). Funciona como catalisador ou parte de um sistema enzimático associado à formação de clorofila (Jones et al., 1991).

A inibição da formação de clorofila em condições de deficiência de ferro, é causada em parte pela diminuição da síntese de proteínas (Marchner, 1986). De acordo com Menguel \& Kirkby (1987), foram observadas grandes quantidades de ferro em cloroplastos, confirmando que são ricos em ferro, contendo aproximadamente $80 \%$ do total de ferro da planta.

Segundo Terry \& Abadia (1986), o Fe encontra-se na folha preferentemente como Fe-ferrico, presente em proteínas $\mathrm{Fe}-\mathrm{S}$, citocromos e fitoferritina. A outra parte está presente como Fe-ferroso (solúvel), requerido para diversos processos enzimáticos. 
2.2.2. Concentração, deficiência e toxicidade.

Sabe-se que tanto a deficiência como o excesso de micronutrientes causam diminuição na produtividade das plantas, originando injúrias nas mesmas.

Provavelmente de todos os cereais, o arroz seja o mais suscetível a deficiência de ferro, mas como a sua cultura é realizada principalmente em solos inundados, ácidos, com alto teor de $\mathrm{Fe}$ disponível, geralmente não apresenta essa limitação (Vose, 1982); embora quando cultivado em solos secos, aeróbicos, a deficiência de $\mathrm{Fe}$ pode ser um fator limitante em solos ácidos, segundo (IRRI., 1970; Ponnamperuma, 1977). Conforme Malavolta (1985), em solos ácidos como os de Cerrado pode haver falta de Fe na planta, induzida por excesso de $\mathrm{Mn}$ presente no meio, por outro lado a calagem excessiva provocando a elevação do $\mathrm{pH}$ do solo além de 7,0 pode insolubilizar o ferro, causando também deficiência.

Obata (1995), cita que segundo diversos autores as plantas de arroz têm maior requerimento de ferro que outras culturas.

A toxicidade de Fe é um sério problema em arroz irrigado (Fageria \& Rabelo, 1987), podendo ser considerada a maior desordem nutricional em sistemas de cultivos estabelecidos em solos orgânicos inundados (anaerobiose) que contêm Fe reduzido. Genon et al. (1994), encontraram teores foliares maiores que $250 \mu \mathrm{g} \mathrm{g}^{-1}$ induzindo diminuição na absorção de outros nutrientes e consequente redução na produção de grãos.

Segundo Jones et al. (1991), nas plantas em geral a concentração de Fe foliar encontra-se em uma amplitude de 10 a $1000 \mu \mathrm{g} \mathrm{g}^{-1}$ na matéria seca, mais frequente entre 50 e $75 \mu \mathrm{g} \mathrm{g}^{-1}$, por outro lado de acordo com Vose (1982), a faixa normal varia entre $60-300 \mu \mathrm{g} \mathrm{g}^{-1}$, para plantas deficientes 
entre $10-30 \mu \mathrm{g} \mathrm{g}^{-1}$, enquanto que em condições de excesso, 400 a 1000 podem ser encontrados.

Fageria et al. (1981), verificaram que o teor de Fe na parte aérea das plantas de arroz tem aumentado nos diferentes estádios de crescimento com o aumento na concentração de $\mathrm{Fe}$ em solução nutritiva, encontrando que os níveis tóxicos de Fe na parte aérea aos 20 e 40 dias de crescimento foram 680 e $850 \mu \mathrm{g} \mathrm{g}^{-1}$ respectivamente.

Normalmente, o nível tóxico de $\mathrm{Fe}$ nas plantas segundo Tanaka et al. (1966) e Foy et al. (1978) está entre 300 a 500 ppm, já outros pesquisadores, Fageria \& Rabello (1987), analizando a parte aérea encontraram valores maiores do que $600 \mu \mathrm{g} \mathrm{g}^{-1}$ como tóxicos para a cultura do arroz. Segundo Malavolta (1978), o teor crítico indicador de deficiência no estado de perfilhamento é de $70 \mu \mathrm{g} \mathrm{g} \mathrm{g}^{-1}$, e de toxidez $300 \mu \mathrm{g} \mathrm{g}^{-1}$, ambos valores na lâmina foliar, e variando em função do cultivar. Segundo Howeler (1973), plantas com sintomatologia de bronzeamento podem apresentar conteúdos de Fe nas folhas que variam entre 100 e $1000 \mu \mathrm{g} \mathrm{g}^{-1}$. Por outro lado De \& Mandal (1957) e Ishizuka (1961), determinaram que o nível de ferro tóxico para as plantas de arroz é variável, dependendo do tipo e fertilidade do solo e do cultivar, podendo os valores variarem entre 50 a $1680 \mu \mathrm{g} \mathrm{g}^{-1}$ na parte aérea das plantas.

Segundo Ottow et al. (1983), sintomas de toxicidade típica de Fe foram encontradas com quantidades de 10 a $40 \mu \mathrm{g} \mathrm{g}^{-1} \mathrm{de} \mathrm{Fe}^{2+}$ na solução.

A toxidez de ferro pode estar diretamente relacionada com a absorção excessiva do nutriente pela planta provocando danos as células (toxicidade direta) ou indiretamente afetando outros nutrientes induzindo deficiência pelo excesso do mesmo (Fageria et.al., 1981; Ottow et.al., 1983). 
Jugsujinda \& Patrick (1993), pesquisando níveis de ferro em plantas de arroz encontraram que $51 \%$ das amostras de tecido de folhas das plantas continham níveis maiores que $300 \mathrm{mg} \mathrm{kg}^{-1}$ de $\mathrm{Fe}$, concordando com o nível crítico proposto por Tanaka \& Yoshida (1970). São comumente observadas diferencias intervarietais em níveis críticos de toxidez ou deficiência (Vose, 1982; Foy, 1983; Marschner, 1986).

Segundo Barbosa Filho et al. (1983), a toxicidade de Fe também conhecida como "bronzing" ou bronzeamento, tem-se constituído em algumas regiões do Brasil, tais como a zona de Mata em Minas Gerais, Santa Catarina, Rio de Janeiro e Pará, em um fator limitante para o desenvolvimento normal das plantas de arroz irrigado por submersão.

Ponnamperuma et al. (1955), descrevem uma desordem nutricional caracterizada por amarelecimento foliar ou bronzeamento, com reduzido crescimento e produção, apresentando-se na cultura de arroz irrigado acentuándo-se em solos deficientemente drenados de Africa e Asia, atribuindo o mesmo a uma provável toxicidade de Fe.

Howeler (1973), relatou que sintomas de coloração laranja nas folhas são causados por efeito indireto do Fe sobre a absorção de outros nutrientes principalmente $\mathrm{P}$ e $\mathrm{Mg}$ em solos ácidos, e a sintomatologia de bronzeamento seria consequência de um efeito direto de altas concentrações de Fe na solução sobre a planta. Em algumas situações, o cultivo de arroz em solos baixos é afetado por uma combinação da toxidez de Fe direta e indireta, resultando em uma ampla faixa de intensidade de cores alaranjadas. Ottow et al. (1983), citaram que multiplas deficiências nutricionais são encontradas associadas com toxicidade de $\mathrm{Fe}$.

Conforme Tadano (1975), a toxicidade de Fe em plantas de arroz cultivadas em solos ácidos, é conhecida como "bronzing" em Sri Lanka 
(Ceilão), "Akagare tipo I", no Japão, e "Akiochi" na Coréia com suspeita de ser causado por toxidez de Fe.

Ponnamperuma et al. (1955), estudando as possíveis causas de bronzeamento em plantas de arroz cultivadas em solos irrigados, encontraram uma estreita relação entre a severidade da sintomatología e a concentração de produtos reduzidos especialmente Fe-ferroso.

Segundo Tadano (1975) e Brown \& Jones (1977), a toxidez estaria associada com aumento na absorção e translocação de Fe para a parte aérea; já a capacidade que tem a planta de arroz de absorver o oxigênio pela parte aérea, transportá-lo para as raízes e difundi-lo na rizosfera (Raalte 1941; Jensen et.al. 1967), enquanto que considerando a redução e absorção de ferro que é variável entre cultivares, poderia ser mais tolerante aquele que possua alta taxa de difusão de oxigênio na rizosfera que outro com menor capacidade de oxidação (Fageria, 1989). Segundo Tadano (1975) e Foy (1978), a taxa de translocação do Fe na planta decresce com alto teor de $\mathrm{P}, \mathrm{K}, \mathrm{Mg}, \mathrm{Ca}$ e $\mathrm{Mn}$, portanto a planta de arroz deficiente nestes nutrientes acumula mais ferro na parte aérea, aumentando desse modo a suscetibilidade à toxidez do nutriente.

Um numero de estratégias diferentes são empregadas pelas plantas para superar problemas de deficiência de ferro (Marschner, 1986). Para o caso das dicotiledoneas, reações de deficiência de Fe usualmente consistem em acidificação da rizosfera e excreção de ácidos orgânicos, que conduzem a uma elevada mobilização e transporte de $\mathrm{Fe}^{3+}$ desde o solo para sítios de redução e absorção nas raízes (Alloush \& Sanders, 1990).

Existem alguns mecanismos de tolerância a toxidez, como o citado por Nishizono et.al. (1987); Taylor (1987); Allan et al. (1990), onde a acumulação apoplástica tem sido pensada como um possível mecanismo de 
tolerância das plantas à toxicidade de metais pesados ou adaptação à deficiência de nutrientes (Lineham, 1984; Longnecker \& Welch, 1986). Íons acumulados no apoplasto podem ser encontrados na parede celular ou podem precipitarem-se como hidróxido ou fosfato, como no caso do $\mathrm{Fe}$ e Al.

As gramíneas incluindo cereais de grãos como o arroz, segundo Salisbury \& Ross (1991), em geral respondem a deficiência de Fe, através da formação e liberação de ligações fortes que quelatizam especificamente $\mathrm{Fe}^{3+}$. Estas ligações são chamadas sideroforos ou mais especificamente fitosideroforos. Atualmente o ácido avenico e ácido mugineico são os dois mais estudados, que atuam ligando o ferro, os quais são absorvidos juntos pela planta, provavelmente este Fe que é reduzido previamente, é libertado imediatamente e utilizado pela planta, sendo os fitosideroforos libertados desde as raízes para novamente carregar $\mathrm{Fe}$ do meio circundante.

\subsubsection{Fe e características fisiológicas}

Fageria et al. (1981), verificaram que a produção de matéria seca e o crescimento do cultivar de arroz IAC-435 foram reduzidos, quando a concentração de $\mathrm{Fe}$ em solução nutritiva foi maior que $80 \mathrm{mg} \mathrm{L}^{-1}$, e também encontraram que altos níveis inibiram a formação de novas raízes ativas.

Fageria (1989), comenta que altas concentrações de ferro provocaram redução nos parâmetros de crescimento em plantas de arroz, como: altura de planta, número de perfilhos, comprimento de raiz e peso de matéria seca da parte aérea e raiz de diferentes cultivares de arroz, com grandes variações entre cultivares; verificou redução significativa do peso da matéria seca da parte aérea e 
das raízes com valores acima de $20 \mu \mathrm{g} \mathrm{g}^{-1}$ de ferro. $\mathrm{O}$ mesmo autor tem encontrado que a parte aérea da planta de arroz é mais sensível à toxidez de ferro do que as raízes.

Barbosa Filho et.al. (1983), estudando a produtividade de arroz em dois solos, um com alta concentração de Fe $\left(730 \mu \mathrm{g} \mathrm{g}^{-1}\right)$ e outro com concentração menor (420 $\mu \mathrm{g} \mathrm{g}^{-1}$ ), encontraram que o número de perfilhos, comprimento total das raízes, produção de matéria seca e rendimento de grãos das plantas cultivadas no solo com alto teor de $\mathrm{Fe}$ foram significativamente menores do que no solo com menor concentração do mesmo, atribuindo este resultado à alta toxicidade de Fe naquele solo, associando a severidade da toxicidade aos teores de macro e micronutrientes na parte aérea das plantas de arroz

Yoshida \& Yamamuru (1986), pesquisando possíveis causas de sintomas típicos "Akagare" em arroz, determinaram que a origem da mesma devia-se à toxicidade de $\mathrm{Fe}$, associada a condições de solo inundado com deficiência de $P$.

É característica da toxidez de Fe, uma primeira manifestação de um bronzeamento claro nas folhas, que dependendo da variedade pode iniciar-se apresentando um amarelecimento, seguida de pequenas pontuações marrons nas folhas basais, culminando com a decoloração e expansão desde a extremidade superior das folhas em direção à base das mesmas, com posterior secamento $\mathrm{e}$ morte das folhas (Ponnamperuma et.al., 1955; Howeler, 1973; Tadano, 1975; Barbosa Filho et.al. 1983; Ottow et.al. 1983; Duarte et.al. 1993).

As raizes de plantas afetadas apresentam-se escassas, grossas, curtas, e frequentemente de coloração avermelhada escura com pouca ou nenhuma ramificação (Howeler, 1973; Barbosa Filho, 1987). Por sua vez Jugsujinda \& Patrick (1993), concluiram que o sistema radicular em plantas de arroz afetadas por 
toxidez de ferro apresenta raízes curtas e altamente ramificadas com tegumento laranja escuro para marrom, por causa de óxidos de ferro e $\mathrm{Mn}$, provocando redução na capacidade de absorção de nutrientes, também têm observado a presença de raízes brancas não ativas.

Segundo Kampfenkel et al. (1995), estudando excesso de ferro em tabaco (Nicotiana plumbaginifolia), encontraram que excesso de ferro na solução provocou diminuição do $40 \%$ na taxa fotossintética, acompanhada de fotoinibição, aumento na redução do fotossistema II e maior energização nos tilacoides, estimulando a fotorrespiração devido a que dobra a atividade da catalase. Indicando isto, que a concentração de ferro celular deve ser regulada para evitar dano celular provávelmente por estresse oxidativo, induzido por este. Moderadas variaçãoes no conteúdo de ferro foliar, provoca dramático efeito sobre o metabolismo.

O sintoma típico de deficiência de ferro, consiste primeiramente em uma clorose internerval das folhas mais novas, e quando a mesma torna-se mais severa, as folhas ficam totalmente amareladas, atingindo também as folhas mais maduras (Jones, 1991; Fageria, 1994).

Segundo Salisbury \& Ross (1991), a causa do amarelecimento por deficiência de $\mathrm{Fe}$, é devido a uma rápida inibição da formação de clorofila, sendo que o grupo de enzimas que catalizam determinadas reações da síntese da clorofila requerem de Fe-ferroso. $\mathrm{O} F e$ acumulado nas folhas maduras é relativamente imóvel no floema, talvez porque seja precipitado internamente em células das folhas como óxido insolúvel ou na forma de composto inorgânico ou orgânico como fosfato férrico, e talvez outros compostos insolúveis não conhecidos, sejam formados. De acordo com Taiz \& Zeiger (1991), a baixa mobilidade do $\mathrm{Fe}$ pode ser devido à precipitação nas folhas maduras como óxidos, 
fosfatos insolúveis ou pela formação de complexos como a fitoferritina, como uma ligação Fe-proteína, precipitação que reduz a mobilização do metal no floema prejudicando a translocação a grandes distâncias.

Alloush \& Sanders (1990), encontraram que deficiência de Fe em plantas de grão de bico provocaram diminuição no crescimento e absorção de nutrientes, com maior efeito sobre ânions que cátions, aumentando o de $\mathrm{H}^{+}$, enquanto que plantas normais captaram mais ânions que cátions, com um claro efluxo de $\mathrm{OH}^{\circ}$.

Segundo Barbosa Filho et al. (1983), a relação entre os teores de macro e micronutrientes e o teor de Fe é importante para compreender o comportamento diferencial de um mesmo cultivar de arroz em função do tipo do solo e da concentração de Fe na parte aérea, que de acordo a Howeler (1973), a severidade da toxicidade de ferro está associada, principalmente aos teores de $\mathrm{P}, \mathrm{K}$, $\mathrm{Ca}$ e $\mathrm{Mg}$ das folhas. $\mathrm{O}$ efeito de deficiência de Fe sobre a absorção de outros nutrientes não está bem entendida, mais diminui a captação de ânions e assimilação de nitrogênio (Egmond \& Aktas, 1977).

Por sua vez Fageria et al. (1981), encontraram que a absorção de $\mathrm{P}, \mathrm{K}, \mathrm{Ca}$ e $\mathrm{Mg}$ diminuiu com o incremento da concentração de Fe na solução, determinando que a toxidez pode estar associada a outros desordens nutricionais. Para Fageria (1981); Howeler (1973); Chen et.al. (1980) e Wang et.al. (1994) pode ser causado devido ao excesso de Fe no meio de crescimento com deposição nas raízes e na rizosfera poderia estar bloqueando a absorção de nutrientes através da camada de óxido férrico depositada no sistema radicular, provocando assim um efeito indireto da toxidez de $\mathrm{Fe}$ induzindo deficiência principalmente de $\mathrm{P}, \mathrm{K}, \mathrm{Ca}$ e $\mathrm{Mg}$, por diminuição da capacidade de absorção das raízes, juntamente com a inibição da formação de novas raízes brancas ativas. Segundo (Howeler, 1973; 
Barbosa Filho, 1987) em determinadas condições as plantas podem sofrer o efeito direto da toxidez de $\mathrm{Fe}$, onde a absorção excessiva de Fe pela planta resulta em uma sintomatología de bronzeamento nas folhas das mesmas.

Segundo Tadano (1975), plantas deficientes em K, Ca, Mg, P e Mn, são mais suscetíveis a toxidez de ferro que plantas com níveis normais destes nutrientes.

A deficiência induzida de $\mathrm{K}, \mathrm{Ca}$ e $\mathrm{Mg}$ na solução nutritiva ou do solo aumenta a absorção de Fe, com consequente elevação da toxidez, sendo que baixos teores de $\mathrm{K}$ e $\mathrm{P}$ parecem acentuar a toxidez por decréscimo da capacidade de oxidação das raízes (Trolldenier, 1977).

Holmes (1960), cita que o Fe solúvel presente em uma solução nutritiva com $\mathrm{pH}$ ao redor de 4 tem diminuído severamente com aumento do $\mathbf{P}$ solúvel, pois, frente ao excesso de $\mathrm{P}$ o $\mathrm{Fe}$ foi precipitado como $\mathrm{Fe}^{3+}$ - fosfato insolúvel. Segundo Ayed (1970), o excesso de $\mathrm{P}$ também interfere com a mobilidade e funcionalidade do Fe na planta. A deficiência de Fe começa com índices $\mathrm{P} / \mathrm{Fe}$ superiores a 60 (Yunusa Yusuf, 1980).

Lahar \& Zipori (1978), concluíram que altas concentrações de Ca próximas à superfície das raízes constituíram-se em uma barreira química para o movimento de Fe-EDTA em direção às raízes. Singh \& Sinha (1977), observaram que $\mathrm{Fe}^{3+}$ foi rapidamente deslocado em um solo calcário por $\mathrm{Ca}^{2+} \mathrm{e}$ $\mathrm{Mg}^{2+}$. Segundo Burstrom (1968), altas quantidades de $\mathrm{Ca}^{2+}$ na solução do solo ou nas plantas têm um efeito fisiológico negativo sobre o ferro ativo. Em um solo deficiente em Fe, Salardini \& Murphy (1975), encontraram que aplicações de Fe diminuíram as concentrações de $\mathrm{Ca}, \mathrm{Mg}, \mathrm{Zn}$ e $\mathrm{Mn}$ na planta. 
Altas concentrações de $\mathrm{Fe}$ podem resultar na competição entre este nutriente e Mg por sítios de absorção, segundo (Moore \& Patrick, 1989; Moore et.al. 1990), suficiente para diminuir o conteúdo de Mg nas folhas.

Barbosa Filho et.al. (1983), encontraram que a relação N:Fe na parte aérea foi 5 vezes maior no solo sem problema de $\mathrm{Fe}$, e duas vezes maior para as relações $\mathrm{P}: \mathrm{Fe}, \mathrm{K}: \mathrm{Fe}, \mathrm{Ca}: \mathrm{Fe}, \mathrm{Mg}: \mathrm{Fe}, \mathrm{Zn}: \mathrm{Fe}, \mathrm{Cu}: \mathrm{Fe}$ e $\mathrm{Mn}: \mathrm{Fe}$, concluindo que estas relações são mais importantes do que a quantidade absoluta de Fe no tecido, e que a toxicidade de $\mathrm{Fe}$ depende do balanço nutricional das plantas.

Conforme Jones et al. (1991), os micronutrientes Fe e Mn estão estreitamente correlacionados na nutrição de plantas, onde estudos realizados em hidroponia têm mostrado que altos níveis de Fe reduzem o conteúdo de Mn na planta e vice versa, provávelmente por antagonismo, concordando com (Tanaka \& Navasero, 1966; Zaharieva, 1986), onde o Mn pode deslocar o Fe desde seu complexo metal orgânico, e as plantas cloróticas apresentar altos índices $\mathrm{Mn} / \mathrm{Fe}^{2+}$ ou por diminuição das reações de oxi-redução (Zaharieva, 1986). O deslocamento do $\mathrm{Mn}$ por quelados de Fe pode ser uns dos responsáveis pela depressão do $\mathrm{Mn}$. $\mathrm{Na}$ mesma citação, estes pesquisadores colocaram uma relação $\mathrm{Fe} / \mathrm{Mn}$ de $2 / 1$ e $1 / 2$ nas folhas de um grande número de plantas, sem provocar efeitos adversos no crescimento das mesmas. Segundo Malavolta (1985), o Mn inibe competitivamente a absorção de ferro.

De acordo com Yang et al. (1993), a deficiência de $\mathrm{Zn}$ tem sido associada a altos níveis de $\mathrm{Fe}^{2+}$ e $\mathrm{Mn}^{2+}$ em arroz cultivado sobre solos inundados.

Conforme Mengel \& Kirkby (1987), a deficiência de Fe é caracterizada por diminuição na produção de clorofila; já cloroplastos com adequado fornecimento de $\mathrm{Fe}$, formaram numerosos tilacoides; em cloroplastos 
deficientes em Fe há diminuição do número de tilacoides. Spiller \& Terry (1980), citado por Mengel \& Kirkby (1987), têm verificado que a deficiência de ferro causa diminuição na síntese de membranas do tilacoide e uma depressão na capacidade fotoquímica da fotossíntese..

\subsubsection{Fe e clorofila}

O Fe participa na síntese de clorofila, embora não seja parte constitutiva da molécula da mesma (Taiz \& Zeiger, 1991).

Barakiva \& Lavon (1968), encontraram correlação significativa e positiva entre o teor de clorofila e o ferro no substrato, em folhas de limoeiro sofrendo diminuição tanto de clorofila "a" como de clorofila "b".

Segundo Bergmann (1992), o Fe não faz parte da molécula de clorofila, mas é considerado o elemento que mais influencia diretamente na síntese desse pigmento. O Fe é um constituinte do precursor da clorofila, implicado também na síntese do pigmento através de vários sistemas enzimáticos. A ligação Fe-9-protoporfirina é considerada como um precursor imediato da síntese da clorofila, e sua concentração em plantas deficientes em Fe é muito baixa (Machold \& Stephan, 1969).

Em folhas de girassol Jacobson \& Oertli (1956), encontraram adequadas relações entre o suprimento de $\mathrm{Fe}$ e concentração de clorofila. Resultados similares foram obtidos para caupí por Marsh et.al. (1963), milho (Agarwala et.al., 1965).

Yunusa Yusuf (1980), cita que em plantas de sorgo, níveis de Fe influenciaram grandemente na concentração de clorofila quando crescendo em 
solos com suficiente $\mathrm{Fe}$, onde o conteúdo de clorofila foi de 2,1 e 1,4 vezes mais que plantas crescendo em solos com baixos níveis do micronutriente, concordando com Sideris \& Young (1956), que o total de clorofila em folhas de abacaxi foi de 2,2 vezes maior em plantas crescendo com níveis adequados de Fe que em plantas deficientes. Uma marcada correlação entre suprimento de $\mathrm{Fe}$ e conteúdo de clorofila foi verificado por O’ Sullivan (1969), pesquisando com forrageiras. Agarwala (1965), observou uma correlação linear entre concentração de clorofila e suprimento de Fe em milho, com valores acima da concentração de $0,5 \mu \mathrm{M} F$. Deficiência de Fe em caupí, segundo Marsh et.al. (1963), limitaram a formação de ácido $\delta$-aminolevulinico, que participa da síntese de clorofila. Segundo Yunusa Yusuf (1980), o limitado suprimento de Fe, limitou mais a síntese de clorofila "a" que clorofila "b".

Vorm \& Diest (1979), ao estudar a relação entre Fe/Mn e conteúdo de clorofila em arroz, não encontraram correlação entre conteúdo de Fe e clorofila nas folhas, devido provávelmente à inativação do Fe nas folhas causado por altos níveis de Mn o qual foi negativamente correlacionado com conteúdo de clorofila.

De acordo com Taiz \& Zeiger (1991), a participação específica do Fe na síntese da clorofila é ainda objeto de investigação.

Conforme Mengel \& Kirkby (1987), nas folhas jovens, uma diminuição no conteúdo de clorofila é o sintoma visual mais óbvio de deficiência de $\mathrm{Fe}$, devido a que este é responsável direto da síntese de clorofila. O precursor da clorofila é o ácido $\delta$-amino levulinico (ALA), sendo o índice de formação de ALA regulado por Fe em folhas de cevada (Miller et.al., 1982).

Machold (1969), estudando Fe e conteúdo de clorofila em folhas de tomate, tem encontrado que com suprimento normal de Fe o conteúdo de 
clorofila atingiu $3,52 \mathrm{mg} \mathrm{g}^{-1}$, sendo que no tratamento sem $\mathrm{Fe}$, o conteúdo de clorofila diminuiu para $0,25 \mathrm{mg} \mathrm{g}^{-1}$. Landsberg (1981), verificou uma diminuição do conteúdo relativo de clorofila de 100 para 12 em tratamentos com e sem Fe, respectivamente, em folhas de aveia.

Segundo Malavolta (1979), 75 \% do Fe da folha encontra-se nos cloroplastos e, quando há deficiência desse micronutriente, há redução no teor de clorofila, o número de cloroplastos diminui e há menor quantidade de grana nos mesmos. Terry \& Low (1982), têm mostrado que o conteúdo de clorofila está diretamente relacionado ao total do conteúdo de Fe na folha; análise de folhas cloróticas com folhas testemunhas revelaram maior conteúdo de Fe nas primeiras que nas segundas. Clorofila, proteinas e transporte de elétrons, aumentam com fornecimento de ferro (Shuman, 1994).

Segundo Pushnik et.al.(1984), a primeira resposta associada a deficiência de Fe na planta, é a diminuição da clorofila e como consequência a perda da capacidade fotossintética, ocasionando redução na produção. Conforme Terry \& Rao (1991), os pigmentos como as clorofilas "a", "b", e carotenos diminuem em proporção com a deficiência de Fe; já xantofilas diminuem em menor grau, pois as folhas deficientes em Fe são caracterizadas por conter mais xantofilas que outros.

\subsubsection{Raízes da planta de arroz e seu ambiente}

As raizes da planta de arroz como outras espécies, segundo Ponnamperuma (1964), têm alta demanda de oxigênio devido à energia que requerem determinados processos vitais para as plantas, como a absorção ativa de nutrientes. Uma consequência da inundação do solo é a faltà ou escassez de 
oxigênio, cujo suprimento na planta de arroz é direcionado desde a parte aérea difundindo-se através do aerênquima para as raízes.

O sistema radicular das plantas de arroz é caracterizado por ser pouco profundo e com forte poder oxidativo, considerado uma importante adaptação fisiológica que permite à planta crescer em meios reduzidos (Tanaka \& Navasero, 1966; Okuda \& Takahashi, 1984). A zona oxidada desenvolvida na rizosfera, segundo Takijima (1965), atua como uma área de proteção contra efeitos prejudiciais que substâncias redutoras semelhantes a Fe-ferroso e sulfitos podem causar às raízes. Segundo Obata (1995), é baixa a capacidade de absorção de ferro pelas raízes de plantas de arroz quando comparada com outras culturas, tendendo o arroz a ser suceptível a clorose por ferro, sob condições de deficiência.

$\mathrm{O}$ ferro na forma $\mathrm{Fe}^{2+}$ disponível para a planta, segundo (Ponnamperuma, 1964; Tanaka \& Navasero, 1966; Howeler, 1973) é oxidado desde a sua forma Fe-ferroso para formas insolúveis pelas raízes de arroz, e depositados sobre a superfície das mesmas. Da mesma forma Tanaka et al. (1966), encontraram grandes quantidades de Fe depositado na superficie e na epiderme das raízes de arroz, mas não determinaram a natureza química e mineralógica do fenómeno. Bacha (1976) e Bacha \& Hossner (1977) estudaram o precipitado sobre a superfície das raízes de arroz, e concluíram que pela ocorrência sistemática de um máximo na análise de difração de raio $\mathrm{X}$ a $6,26 \AA$, o óxido mineral de ferro tratava-se de lepidocrocita $(\delta-\mathrm{FeOOH})$ como o único componente cristalino dos tegumentos. Chen et al. (1980) identificaram também a goetita $(\delta-\mathrm{FeOOH})$ formada pela oxidação na superfície das raízes.

Concentrações médias de $\mathrm{Fe}$ nas raízes conforme Bacha (1976), são muito maiores que na parte aérea, variando de 122 para $414 \mu \mathrm{g} \mathrm{g}^{-1}$. O 
mesmo autor analisando o tegumento tem encontrado valores de 915 a $24272 \mu \mathrm{g} \mathrm{g}^{-1}$ de Fe na matéria seca da raiz.

Bacha (1976), ao estudar altas doses de Fe em solução, verificou que nos tratamentos contendo as menores doses as raízes de arroz apresentaram uma coloração ferruginosa, originada pela cobertura com ferro, enquanto que com as doses maiores tem observado cores marrom-laranja escuro, que de acordo com vários autores uma banda marrom de hidróxido férrico ao redor das raízes de arroz é uma característica da cultura. Quando o citado autor não aplicou doses elevadas de $\mathrm{Fe}$ no meio nutritivo, encontrou que as mesmas apresentavam-se com cor branca.

Clarkson \& Sanderson (1978), têm encontrado em plantas de trigo que principalmente as regiões apicais da raiz e não as partes basais, são capazes de absorver Fe.

Segundo Wang et al. (1994), a rizosfera é uma importante microregião onde existe uma interação direta entre as raízes e o solo, resultando em uma complicada interação de elementos. Otte et al. (1989), citado por Wang et al. (1994) verificaram que a deposição de Fe nas raízes pode comprometer a absorção de zinco. Wang et al. (1994), também encontraram que a acumulação de Fe na rizosfera poderia bloquear a absorção de $\mathrm{P}$ e diminuição na absorção de $\mathrm{Si}$ e Ca pela planta de arroz, e com aumento na deposição do mesmo nas raízes e na rizosfera poderia bloquear a absorção de outros nutrientes.

Conforme Tadano (1975), as raizes de arroz possuem três estratégias para evitar a toxidez de ferro, mesmo em concentrações altas, sendo as mesmas: a) diminuição da concentração do ferro disponível no meio de crescimento, por aumento no potencial redox e liberação de $\mathrm{O}_{2}$ para o meio de crescimento, oxidando assim o Fe-ferroso em Fe-ferrico, de acordo com Kirk et.al. 
(1993); b) Através da força de exclusão do ferro, interrompendo a entrada do mesmo que atinge a superfície radicular para depois ser absorvido, essa força é operada pela respiração quando a concentração de ferro no meio de crescimento é elevada.; c) força de retenção do ferro, interrompendo a translocação do mesmo que entrou na raiz para dirigir-se em direção a parte aérea, onde parte do ferro que entra na raiz é translocado para a parte aérea e outra é retida nas raízes.

Bacha \& Hossner (1977), determinaram que a ocorrência de precipitados de óxidos de $\mathrm{Fe}$ e $\mathrm{Mn}$ envolvendo as raízes são função da concentração dos mesmos no solo, ao mesmo tempo que a habilidade específica das plantas de arroz para transportar oxigênio desde as partes aéreas para as raízes em condições anaeróbicas, realizando através de espaços gasosos (aerênquima) conectado com espaços de ar do sistema radicular, movendo-se o $\mathrm{O}_{2}$ nestes canais dentro da raiz e para o solo, oxidando a rizosfera. Esta zona de oxidação da rizosfera atua como área de proteção contra quantidades tóxicas de substâncias reduzidas prejudiciais como Fe-ferroso (Takijima, 1965). Os nutrientes Fe e Mn são oxidados desde suas formas reduzidas (solúveis) pelas raízes e depositados (precipitado) sobre a superficie das mesmas, (Yoshida \& Takahashi, 1958; Okuda \& Takahashi, 1964; Ponnamperuma, 1964; Takijima, 1964; Tanaka \& Navasero, 1966; Howeler, 1973), resultando em uma diminuição na absorção destes nutrientes.

\subsection{Fe no solo}

\subsubsection{Níveis de ocorrência e formas}

Ferro é um nutriente essencial para as plantas, que em concentrações excessivas no substrato, retarda o crescimento e desenvolvimento (Fageria et.al. 1981; Barbosa Filho et.al. 1983). 
Segundo Alam (1994), o incremento na solubilidade do Fe em solos inundados é benéfico para a cultura do arroz, o qual tem maiores exigências deste elemento que outras plantas, por outro lado solos com níveis tóxicos de ferro solúvel, superando $300-500 \mu \mathrm{g} \mathrm{g}^{-1}$, geralmente provocam bronzeamento nas plantas de arroz (Ponnamperuma et.al 1955; Tanaka et.al. 1966).

Fageria (1989), considera que para avaliar cultivares de arroz para tolerância a toxidez de ferro em solução nutritiva, deve ser considerada baixa toxidez entre 40 e $60 \mu \mathrm{g} \mathrm{g}^{-1}$, e alta toxidez superior a $60 \mu \mathrm{g} \mathrm{g}^{-1} \mathrm{de} \mathrm{Fe}$.

Sintomas de toxidez na parte aérea e raizes das plantas de arroz ocorrem em solos frequêntemente em associação com salinidade, deficiência de fósforo e baixa concentração de bases (Ota, 1968; Ponnamperuma et.al. 1955).

Fageria (1981), em sua pesquisa, verificou que na concentração de $\mathrm{Fe}$ de $2,5 \mathrm{mg} \mathrm{L}^{-1}$ em solução nutritiva as plantas apresentaram crescimento normal, já com valores superiores a $80 \mathrm{mg} \mathrm{L}^{-1}$ de $\mathrm{Fe}$ na solução nutritiva provocaram redução significativa no crescimento, manifestando sintoma típico de bronzeamento em concentrações de $160 \mathrm{mg} \mathrm{L}^{-1}$ de $\mathrm{Fe}$.

Fageria (1990), verificou que níveis maiores de $160 \mu \mathrm{M}$ diminuíram o comprimento de raiz em plantas de arroz, e também tem determinado que com o aumento do nível de Fe incrementou-se a concentração e absorção de Fe na raiz e parte aérea. Pelo contrário a absorção de $\mathrm{P}, \mathrm{K}, \mathrm{Ca}, \mathrm{Mg}$ e $\mathrm{S}$ foi diminuída com o incremento dos níveis de $\mathrm{Fe}$ no meio de crescimento, não assim com $\mathrm{Mn}, \mathrm{Zn}$ e $\mathrm{Cu}$ que aumentaram.

Benckiser et al. (1984), observaram toxicidade de Fe em solos com 30 a $3000 \mathrm{mg} \mathrm{L}^{-1}$ de $\mathrm{Fe}^{2+}$ a valores de $\mathrm{pH}$ de 3 para 7. Solos típicos com toxicidade de $\mathrm{Fe}$ são caracterizados por baixas quantidades de $\mathrm{P}, \mathrm{K}, \mathrm{Ca}$ e $\mathrm{Mg}$ mais que por baixo $\mathrm{pH}$ ou altas quantidades de $\mathrm{Fe}$ solúvel. $\mathrm{O}$ arroz apresenta grandes 
mudanças metabólicas influenciando na permeabilidade das raízes; plantas de arroz irrigado bem nutridas crescendo ativamente, possuem uma elevada proteção do excesso de absorção de $\mathrm{Fe}$, por oxidação do mesmo.

O Ferro, embora ocorra em níveis bastante elevados nos solos, em determinadas situações encontra-se com teores solúveis extremadamente baixos, provocando sintomas de deficiência, especialmente quando as condições químicas do solo favorecem a insolubilização (Bataglia, 1991; Fageria et.al., 1994). O nível crítico de ferro segundo Malavolta (1987) e Fageria et al. (1991) varia de cultivar para cultivar, situando-se geralmente em torno de $5 \mathrm{mg} \mathrm{kg}^{-1}$, portanto a deficiência de ferro em culturas anuais como o arroz de sequeiro, é devido à baixa disponibilidade ou absorção. Por outro lado para Lopes (1983), o valor do nível crítico de Fe seria menor a $5 \mathrm{mg} \mathrm{kg}^{-1}$.

Tisdale et al. (1985), descreveram que a clorose é causada por: desequilíbrio de íons metálicos, tais como $\mathrm{Cu}$ e $\mathrm{Mn}$; excesso de $\mathrm{P}$ no solo; uma combinação de $\mathrm{pH}$ elevado por excesso de calagem; baixas temperaturas, alta umidade e altos níveis de $\mathrm{HCO}_{3}$ no ambiente radicular.

Segundo Vose (1982), a toxicidade de Fe não é tão comum como a deficiência, sobre solos ácidos onde o $\mathrm{Fe}$ encontra-se disponível como $\mathrm{Fe}^{2+}$ pode converter-se tóxico para as plantas, geralmente associado a drenagem deficiente, e consequentemente altas condições redutoras, como em determinadas situações para a cultura do arroz. (Obata, 1995)

\subsubsection{Disponibilidade}

A toxicidade de $\mathrm{Fe}$ que ocorre geralmente em solos inundados é bastante complexa. $\mathrm{O}$ ferro existe na forma de $\mathrm{Fe}^{3+}$ em condições aeróbicas, 
enquanto que quando é inundado este é reduzido para $\mathrm{Fe}^{2+}$ aumentando a sua concentração na forma disponivel para as plantas (Ponnamperuma, 1965). Conforme (Mengel \& Kirkby, 1987) a disponibilidade de Fe-inorgânico é altamente dependente do $\mathrm{pH}$ do solo.

Segundo Bacha (1978), condições de solo inundado são necessárias para que a cultura de arroz atinja ótimas produções. A eliminação do ar do solo pela água de irrigação provoca diversas transformações, aumentando o número de microorganismos anaeróbicos. As mudanças eletroquímicas acompanhando a redução do solo são: a) diminuição do potencial redox; b) aumento de pH em solos ácidos; e c) aumento na condutância específica. Dentre as alterações químicas encontram-se: a) denitrificação; b) acumulação de produtos resultantes do metabolismo de microorganismos anaeróbicos; c) redução de sulfatos; d) redução de $\mathrm{Mn}$ e Fe, que segundo Alam, 1994) essa mudança na disponibilidade é refletida no aumento nas concentrações nos tecidos; acumulação de amônia; e f) efeitos secundários da redução, como ser aumento na solubilidade de $\mathrm{P}$ e Si e deslocamento de K e outros cátions na solução do solo por $\mathrm{Fe}^{2+} \mathrm{e} \mathrm{Mn}^{2+}$ (Ponnamperuma, 1964).

$\mathrm{O}$ excesso de $\mathrm{Fe}$ nas plantas de arroz origina-se geralmente de alterações químicas do substrato que favorecem o aparecimento da forma reduzida $\mathrm{Fe}^{2+}$, especialmente em condições anaeróbicas como em solos inundados (Bataglia, 1991). Segundo Mengel \& Kirkby (1987), em poucas semanas de inundação pode-se incrementar o nível de Fe solúvel de 0,1 para $50-100 \mathrm{mg} \mathrm{L}^{-1}$. Por outro lado conforme (Ponnamperuma, 1977) citado por (Barbosa Filho, et.al. 1983), a submersão de solos ácidos ricos em matéria orgânica e com alto teor de $\mathrm{Fe}$, pode causar problemas para o arroz, atingindo concentrações de $600 \mathrm{mg} \mathrm{L}^{-1}$ de $\mathrm{Fe}$ em um periodo de 1 a 3 semanas de submersão. 
Em solos com água permanente prevalece a anaerobiose, que segundo Genon et al. (1994), a difusão de oxigênio é muito menor que em solos bem arejados, sendo este rapidamente utilizado pelos microorganismos aeróbicos do solo.

A capacidade de respiração das raízes diminui em solos submersos, devido à presença de inibidores respiratórios, como $\mathrm{H}_{2} \mathrm{~S}$, aumentando a toxidez de ferro (Inada 1966); esta característica é importante na tolerância da toxidez de ferro, sendo que provoca a precipitação do ferro da rizosfera, diminuindo a sua concentração na forma de $\mathrm{Fe}^{2+}$, facilmente disponível para a planta, ocasionando redução da absorção do ferro pela mesma (Tadano 1975; Benckiser et.al., 1984). Aumentando esta capacidade de oxidação em presença de altas concentrações de sílica, potássio e fósforo (Okuda \& Takahashi 1964; Trolldenier 1977).

$\mathrm{O} \mathrm{pH}$ afeta a solubilidade dos compostos de $\mathrm{Fe}$, que conforme Lindsay (1974), quando a disponibilidade de Fe é baixa, não são suficientes os processos de transporte para suprir as necessidades das plantas, razão pela qual as mesmas possuem mecanismos que podem aumentar o suprimento de $\mathrm{Fe}$ às raízes. Um dos mecanismos seria a formação de complexos solúveis ou quelados, podendo-se originar como exudados das raízes, representando substâncias produzidas durante a decomposição da matéria orgânica no solo através da síntese microbiológica. Através de outro mecanismo, as plantas podem aumentar a disponibilidade de $\mathrm{Fe}$, pela sua habilidade de diminuir o $\mathrm{pH}$ e de reduzir $\mathrm{Fe}$-ferrico para Fe-ferroso na rizosfera. As plantas denominadas eficientes possuem maior capacidade de abaixar o $\mathrm{pH}$ e de aumentar a redução na superfície da raiz sob condições de baixos niveis do elemento (Bataglia, 1991) 
Segundo Bataglia (1991), a fração solúvel de Fe no solo é muito pequena em comparação ao total, sendo que através da solubilidade dos óxidos hidratados de Fe-ferrico é controlada a solubilidade do mesmo. Em condições normais de $\mathrm{pH}$ o $\mathrm{Fe}$ é absorvido pelas plantas principalmente na forma de $\mathrm{Fe}^{2+}$ ou quelatos, sendo a forma $\mathrm{Fe}^{3+}$ de baixa solubilidade. A relação entre $\mathrm{Fe}^{3+}$ e $\mathrm{Fe}^{2+}$ nos solos é determinada principalmente pelas condições de aeração, já que em solos inundados a redução de $\mathrm{Fe}^{3+}$ para $\mathrm{Fe}^{2+}$ ocasiona um aumento na disponibilidade para as plantas, promovido este processo pelo metabolismo anaeróbico de bactérias, que em condições normais é muito importante para a produção de arroz.

Conforme Ponnamperuma (1972) condições anaeróbicas desencadeiam um processo de redução a partir da solubilização de óxidos hidratados de $\mathrm{Fe}$, dando origem a $\mathrm{Fe}^{2+}$, com posterior elevação do $\mathrm{pH}$ por consumo de $\mathrm{H}^{+}$, o reverso ocorre ante um aumento na aeração com queda de $\mathrm{pH}$ e oxidação de $\mathrm{Fe}^{2+}$ para $\mathrm{Fe}^{3+}$.

As formas orgânicas de $\mathrm{Fe}$ encontram-se nos solos especialmente como quelatos e complexos, que são importantes para a sua movimentação no perfil do solo, como por exemplo complexos de $\mathrm{Fe}^{2+}$ com polifenóis, ácidos alifáticos e fúlvicos favorecendo a sua mobilização (Oades, 1963).

\subsection{Algumas praticas para reduzir toxidez de $\mathrm{Fe}$}

Existem práticas para reduzir a toxidez de ferro na cultura de arroz, tais como: aumento da drenagem, época de aplicação de água, aplicação de calcário, adubação pesada principalmente de potássio e fósforo, adubação verde e 
emprego de cultivares tolerantes (Ponnamperuma 1958; Ota \& Yamada 1962; Howeler, 1973; Virmani 1977; Barbosa Filho et.al. 1983).

Calagem e aplicação de $\mathrm{P}$ e $\mathrm{K}$ também são eficientes para corrigir a toxidez. As raizes de plantas sadias são capazes de diminuir a absorção excessiva de $\mathrm{Fe}$, ocorrendo o contrário naquelas deficientes em $\mathrm{K}$, ácidos orgânicos, ácido sulfidrico e com dano mecânico (Malavolta, 1978). Barbosa Filho (1983), conclui que não há necessidade de eliminar completamente o Fe tóxico e que a toxicidade pode ser prevenida pelo plantio em várzea úmida e pela aplicação de quantidade econômica de calcário. Conforme resultados obtidos por Winslow et al. (1989), genotipos resistentes e o plantio direto em sulcos podem incrementar grandemente a produção de arroz em solos severamente tóxicos em ferro.

Patra \& Mohanty (1994), concluem que a toxicidade de Fe pode ser reduzida com o uso balançado de fertilizantes (NPK ou NPK + calcário) e sua ocorrência nas condições estudadas foi devido principalmente a stress nutricional. Em experimentos de campo e em vasos, a intensidade da toxicidade de Fe tem sido reduzida ou eliminada por fertilização com $\mathrm{P}, \mathrm{K}$ e $\mathrm{Zn}$, segundo Benckiser et al. (1984). 


\section{MATERIAL E MÉTODOS}

O experimento foi conduzido em câmara de crescimento, no Setor de Nutrição Mineral de Plantas do Departamento de Química da Escola Superior de Agricultura "Luiz de Queiroz", em Piracicaba - SP.

As dimensões da câmara de crescimento na qual realizou-se o ensaio eram de $3,0 \mathrm{~m} \times 5,40 \mathrm{~m}$, com as paredes pintadas com tinta aluminizada, onde a parte iluminada correspondía a uma área de $2,40 \mathrm{~m}$ x 3,0 m. A iluminação da mesma constava da combinação de 72 lâmpadas fluorescentes de $40 \mathrm{w}$ e 28 lâmpadas de vapor de mercúrio de $250 \mathrm{w}$. A intensidade luminosa média, em diferentes pontos ao nível de altura das plantas, foi de 208 micro einsteins.

Com o objetivo de determinar as doses de ferro a serem utilizadas na solução nutritiva para o crescimento do arroz, ajuste da metodologia e condições de funcionamento da câmara, foi conduzido um ensaio preliminar com 4 cultivares de arroz e 4 doses de $\mathrm{Fe}$, onde posteriormente, a partir dos resultados obtidos, instalou-se um ensaio definitivo com dois genótipos de arroz e seis doses 
ajustadas do elemento $\mathrm{Fe}$; experiência desenvolvida seguindo a mesma metodologia que para o erisaio preliminar, com os convenientes ajustes que surgiram do mesmo.

\subsection{Características dos genótipos:}

No ensaio preliminar foram utilizadas sementes de arroz pertencentes aos genótipos IAC 47; IAC 1205; IAC 201 e IAC 165, todos adaptados a condições de sequeiro, cedidos pelo Instituto Agronômico de Campinas - Seção de Cereais. O cultivar IAC 47, conforme Banzatto et al. (1978) foi obtido através do cruzamento artificial entre os cultivares IAC-1246 e a linhagem 58-1391; é de porte médio $(115-120 \mathrm{~cm})$, com bom perfilhamento e de ciclo médio (130-135 dias do plantío à colheita), é indicado para plantios precoces (Outubro-Novembro), é tolerante ao alumínio, segundo Camargo (1984), com grão de excelente qualidade culinária.

O cultivar IAC-165, segundo Usberti Filho et.al. (1987), resultante do cruzamento Dourado Precoce x IAC-1246, apresentando características de porte médio $(100-110 \mathrm{~cm})$, com bom potencial de perfilhamento e ciclo precoce de 110-120 dias de germinação à colheita, moderadamente tolerante a periodos mais ou menos prolongados de seca no estádio vegetativo; possui excelente tolerância a presença de níveis elevados de alumínio $\left(\mathrm{Al}^{3+}\right)$ em solos com elevada acidez, característica semelhante ao do IAC-47 (Camargo \& Camargo, 1985). 
O cultivar IAC-201 (agulhinha de sequeiro) proveniente do cruzamento entre o cultivar IAC-165 e o cultivar Labelle, é de ciclo precoce (110-120 dias) e altura média de $100 \mathrm{~cm}$.

A linhagem IAC-1205 obtida do cruzamento entre o cultivar Lemont (irrigado) x IAC-25 (sequeiro) é de ciclo intermediário (120-130 dias), porte baixo, e de boa produtividade; segundo ensaio preliminar do IAC, podería ser um genótipo suscetível a deficiência de Fe no solo, razão pela qual pensou-se que talvés seria mais tolerante ao excesso de Fe que outros genótipos.

No ensaio definitivo partindo do ensaio preliminar, utilizou-se dois genótipos de arroz IAC-47 e IAC-1205, tendo este último tolerado níveis elevados de Fe na solução nutritiva. Os outros demonstraram alta sensibilidade aos níveis elevados de ferro.

\subsubsection{Obtenção das plântulas}

As sementes dos genótipos de arroz foram colocadas para germinar em papel de germinação umedecido previamente com água destilada na proporção de $2,5 \mathrm{ml}$ de água por grama de papel, na forma de rolo. No germinador, durante o período de germinação a temperatura foi mantida a $25^{\circ} \mathrm{C}$. Logo após a emergência da radícula, foram selecionadas as plântulas a serem transplantadas quanto a uniformidade de tamanho. 


\subsubsection{Instalação e transplante}

Foram utilizados recipientes de isopor revestidos internamente com saco plástico com capacidade para $2,5 \mathrm{~L}$ de solução nutritiva. Nas tampas dos recipientes, foram feitos 18 orificios separados a cada $3 \mathrm{~cm}$ para onde foram transplantadas as plântulas 5 dias após germinação. Inicialmente e durante 7 dias foi utilizada uma solução de elongação, diluída a $50 \%$ da solução completa recomendada por Furlani \& Furlani (1988) para a cultura de arroz, (tabela 2).

\subsubsection{Tratamentos e condução}

No ensaio preliminar foram estudados quatro genótipos de arroz IAC 47; IAC 165; IAC 201 e IAC 1205, e baseado na literatura, foram escolhidos os seguintes níveis de ferro utilizados na solução nutritiva: 0,$5 ; 5,0$; 50,$0 ; 150,0 \mathrm{mg} \mathrm{L}^{-1}$ de solução, respectivamente, colocando Fe-EDTA como fonte do elemento

A composição da solução nutritiva completa foi preparada conforme a desenvolvida por (Yoshida et.al., 1972) para a cultura de arroz com pequenas modificações (tabela 1). O citado autor recomenda para a cultura de arroz em solução nutritiva a concentração de Ferro de $2,0 \mathrm{mg} \mathrm{L}^{-1}$, neste ensaio previo se estudaram níveis menores e maiores de ferro em solução. Camargo (1984), tem cultivado arroz em solução nutritiva selecionando cultivares para tolerância a ferro, utilizando como dose normal $0,5 \mathrm{mg} \mathrm{L}^{-1}$ de ferro em solução, doses elevadas $\left(100 ; 200\right.$ e $\left.400 \mathrm{mg} \mathrm{L}^{-1}\right)$ provocaram sintomas de toxicidade, nos cultivares avaliados. $\mathrm{O}$ pH das soluções foi controlado periodicamente corrigindo 
quando necessário, para $\mathrm{pH} 4,5 \pm 0,5$, com o agregado de $\mathrm{HCl} 0,1 \mathrm{~N}$ ou $\mathrm{NaOH}$ $0,1 \mathrm{~N}$.

Para o ensaio definitivo utilizou-se a solução nutritiva completa baseada em Furlani \& Furlani (1988), para a cultura de arroz, sendo modificada pelo aumento de $0,4 \mathrm{mg} \mathrm{L}^{-1}$ da concentração de $\mathrm{P}$ para $5,0 \mathrm{mg} \mathrm{L}^{-1}$ de $\mathrm{P}$, como é possível observar na Tabela 2.

O Fe foi fornecido como Fe-EDTA, com concentrações do mesmo em $\mathrm{mg} \mathrm{L}^{-1}$ na solução nutritiva de: 0,$125 ; 0,625 ; 1,25 ; 12,50 ; 25,00 \mathrm{e}$ 50,00. Esta solução de ferro preparou-se em base à descrita por Furlani \& Furlani (1988), da seguinte maneira: 1) Dissolveu-se $\mathrm{FeSO}_{4} \cdot 7 \mathrm{H}_{2} \mathrm{O}$ em aproximadamente $400 \mathrm{ml}$ de água destilada; 2) $\mathrm{Na}_{2}$ EDTA em aproximadamente $400 \mathrm{ml}$ de água destilada; 3) Misturando-se as duas soluções, completando-se o volume para 1 litro, e 4) Borbulhando-se a solução final com ar, durante aproximadamente doze horas no escuro

$\mathrm{O}$ pH das soluções foi corrigido em cada substituição da solução nutritiva, que era renovada a cada 7 dias. Acompanhou-se a variação do mesmo durante todo o experimento, mediante leituras periódicas.

Durante o ensaio utilizou-se água desmineralizada para completar quando necessário o volume da solução dos recipientes, compensando assim as perdas devido a transpiração e evaporação. A renovação da solução nutritiva era efetuada a cada 7 dias. 
Tabela 1. Composição das soluções estoque e da solução nutritiva, utilizadas para o estudo preliminar do desenvolvimento de genótipos de arroz em função de doses de ferro. (Yoshida et al, 1972).

\begin{tabular}{|c|c|c|c|c|}
\hline \multicolumn{2}{|l|}{ Soluções estoque } & \multirow{2}{*}{$\begin{array}{l}\text { Relação solução } \\
\text { estoque / solu- } \\
\text { ção nutritiva }\end{array}$} & \multirow{2}{*}{\multicolumn{2}{|c|}{$\begin{array}{l}\text { Concentração } \\
\text { do elemento na } \\
\text { solução nutritiva }\end{array}$}} \\
\hline Componentes & Conc. & & & \\
\hline & $-\mathrm{g} \mathrm{L}^{-1}-$ & $--\mathrm{ml} \mathrm{L}^{-1}--$ & nutrientes & $-\mathrm{mg} \mathrm{L}^{-1}-$ \\
\hline $\mathrm{NH}_{4} \mathrm{NO}_{3}$ & 91,4 & 1,25 & $\mathrm{~N}$ & 40,0 \\
\hline $\mathrm{NaH}_{2} \mathrm{PO}_{4} 2 \mathrm{H}_{2} \mathrm{O}$ & 40,3 & 1,25 & $\mathbf{P}$ & 10,0 \\
\hline $\mathrm{K}_{2} \mathrm{SO}_{4}$ & 71,4 & 1,25 & $\mathbf{K}$ & 40,0 \\
\hline $\mathrm{CaCl}_{2}$ & 88,6 & 1,25 & $\mathrm{Ca}$ & 40,0 \\
\hline $\mathrm{MgSO}_{4} 7 \mathrm{H}_{2} \mathrm{O}$ & 324,0 & 1,25 & $\mathbf{M g}$ & 40,0 \\
\hline Micronutrientes & & 1,25 & & \\
\hline $\mathrm{MnCl}_{2} 4 \mathrm{H}_{2} \mathrm{O}$ & 1,500 & & $\mathrm{Mn}$ & 0,50 \\
\hline$\left(\mathrm{NH}_{4}\right)_{6} \mathrm{Mo}_{7} \mathrm{O}_{24} 4 \mathrm{H}_{2} \mathrm{O}$ & 0,074 & & Mo & 0,05 \\
\hline $\mathrm{H}_{3} \mathrm{BO}_{3}$ & 0,934 & & B & 0,20 \\
\hline $\mathrm{ZnSO}_{4} 7 \mathrm{H}_{2} \mathrm{O}$ & 0,035 & & $\mathrm{Zn}$ & 0,01 \\
\hline $\mathrm{CuSO}_{4} 5 \mathrm{H}_{2} \mathrm{O}$ & 0,031 & & $\mathrm{Cu}$ & 0,01 \\
\hline
\end{tabular}

As soluções foram continuamente arejadas, utilizando-se um compressor de ar. $\mathrm{Na}$ câmara de crescimento foi realizado um controle permanente de: Temperatura através de dois condicionadores de ar, frio e quente, com capacidade para 17000 e 18000 BTUs, ajustando para uma média de $25^{\circ} \pm 4^{\circ}$ Celsius; Umidade do ambiente em aproximadamente $70 \%$, controlando com o umedecimento da câmara; e Iluminação artificial da câmara durante todo o 
período da experiência, com ciclos de iluminação de 16 horas de luz e 8 horas de escuro, controlado através de um timer.

Tabela 2. Composição das soluções estoque e nutritiva para a cultura de arroz. (Furlani \& Furlani, 1988)

\begin{tabular}{|c|c|c|c|c|}
\hline \multirow{2}{*}{$\begin{array}{l}\text { Soluções - Estoque } \\
\text { Componentes }\end{array}$} & \multirow{2}{*}{ Concentração } & \multirow{2}{*}{$\begin{array}{c}\begin{array}{c}\text { Relação solução } \\
\text { estoque/solução } \\
\text { nutritiva. }\end{array} \\
--- \text { ml L }^{-1} \text {--- }\end{array}$} & \multicolumn{2}{|c|}{$\begin{array}{l}\text { Concentração final } \\
\text { da solução nutritiva }\end{array}$} \\
\hline & & & Nutrientes & $\mathrm{mg} \mathrm{L}^{-1}$ \\
\hline $\begin{aligned} \mathrm{A} & -\mathrm{Ca}\left(\mathrm{NO}_{3}\right)_{2} 4 \mathrm{H}_{2} \mathrm{O} \\
& -\mathrm{NH}_{4} \mathrm{NO}_{3}\end{aligned}$ & $\begin{array}{r}270,0 \\
33,8\end{array}$ & 1,2 & $\begin{array}{l}\mathrm{Ca} \\
\mathrm{K}\end{array}$ & $\begin{array}{l}57,3 \\
40,0\end{array}$ \\
\hline $\begin{array}{l}\mathrm{B}-\mathrm{KCl} \\
-\mathrm{KNO}_{3} \\
-\mathrm{K}_{2} \mathrm{SO}_{4}\end{array}$ & $\begin{array}{l}18,6 \\
24,6 \\
44,0\end{array}$ & 0,9 & $\begin{array}{l}\mathrm{Mg} \\
\mathrm{N}-\mathrm{NO}_{3}^{-} \\
\mathrm{N}^{-\mathrm{NH}_{4}^{+}}\end{array}$ & $\begin{array}{r}8,1 \\
59,7 \\
7,4\end{array}$ \\
\hline $\mathrm{C}-\mathrm{Mg}\left(\mathrm{NO}_{3}\right)_{2} 6 \mathrm{H}_{2} \mathrm{O}$ & 142,6 & 0,6 & $\mathbf{P}$ & 5,0 \\
\hline D $-\mathrm{KH}_{2} \mathrm{PO}_{4}$ & 17,6 & 1,2 & $\mathrm{~S}$ & $\begin{array}{l}6,9 \\
76\end{array}$ \\
\hline Micronutrientes & & 0,3 & $\begin{array}{l}\mathrm{Mn} \\
\mathrm{B}\end{array}$ & $\begin{array}{l}0,190 \\
0,110\end{array}$ \\
\hline $\begin{array}{l}\mathrm{Mn}-\mathrm{MnCl}_{2} 4 \mathrm{H}_{2} \mathrm{O} \\
\mathrm{B}-\mathrm{H}_{3} \mathrm{BO}_{3} \\
\mathrm{Cu}-\mathrm{CuSO}_{4} 5 \mathrm{H}_{2} \mathrm{O} \\
\mathrm{Zn}-\mathrm{ZnSO}_{4} 7 \mathrm{H}_{2} \mathrm{O} \\
\mathrm{Mo}-\mathrm{MoO}_{3} \\
\text { Fe-EDTA (conforme tra }\end{array}$ & $\begin{array}{r}2,34 \\
2,04 \\
0,20 \\
0,88 \\
0,16 \\
\text { mento) }\end{array}$ & & $\begin{array}{l}\mathrm{Zn} \\
\mathrm{Cu} \\
\mathrm{Mo}\end{array}$ & $\begin{array}{l}0,060 \\
0,015 \\
0,030\end{array}$ \\
\hline
\end{tabular}

\subsubsection{Colheita e preparo do material}

Antes da colheita do experimento foram avaliados os teores de clorofila, a área foliar e, perfilhamento 
a) Clorofila:

O clorofilômetro [SPAD-502, Soil-Plant Analysis Development (SPAD) Section, Minolta Camera Co., Osaka, Japan ] foi usado para obter valores de clorofila-SPAD de folhas intactas (correspondente à quantidade de clorofila presente na amostra foliar).

As leituras foram realizadas utilizando-se a segunda folha completamente expandida a partir do ápice de cada planta, devido a que os valores das leituras de clorofila das folhas de diferentes posições na planta, em uma avaliação previa, não se diferençaram entre a segunda e terceira folha e nem entre as posições na mesma. Considerou-se como valor representativo de cada tratamento a média de 10 leituras em cada parcela (recipiente).

b) Área foliar:

A avaliação da área foliar foi efetuada sobre plantas representativas em cada tratamento, segundo metodologia descrita por Yoshida et.al. (1972), medindo-se o comprimento e largura máxima de cada uma das folhas, e multiplicando por um valor de " 0,75 ", sendo este um fator de ajuste recomendável para a planta de arroz em todos os estágios.

c) Número de perfilhos:

Foi registrado no momento da colheita o número de perfilhos por planta em cada tratamento, de forma de avaliar o número médio de perfilhos por planta 
d) Colheita e preparo do material

O experimento foi colhido 30 dias após sua instalação, e uma vez descritos e registrados os sintomas visuais mediu-se em cada planta o comprimento da raiz e altura da parte aérea. A seguir as plantas foram fracionadas em raizes e parte aérea. Após retirar as plantas dos recipientes lavou-se o sistema radicular com água deionizada, várias vezes. O material coletado "raízes e parte aérea" foi colocado em estufa (com circulação forçada de ar) a $60^{\circ}-70^{\circ} \mathrm{C}$ de temperatura até apresentar peso constante, posteriormente o material seco foi pesado para determinação de matéria seca das respectivas frações.

A matéria seca das raízes e da parte aérea após secagem e pesagem, foi moída em moinho tipo Willey, para posterior análise química, determinando-se as concentrações de $\mathrm{N}, \mathrm{P}, \mathrm{K}, \mathrm{Ca}, \mathrm{Mg}, \mathrm{Fe}, \mathrm{Mn}, \mathrm{Zn}, \mathrm{e} \mathrm{Cu}$, conforme metodologia descrita por Sarruge \& Haag (1974).

\subsubsection{Características avaliadas}

Para se avaliarem os efeitos dos níveis de ferro sobre o desenvolvimento dos cultivares estudados, foram analisadas as seguintes características:

- Altura da parte aérea e comprimento de raiz (cm).

- Produção de matéria seca da parte aérea e das raízes (g planta $\left.{ }^{-1}\right)$

- Determinação química de $\mathrm{N}, \mathrm{P}, \mathrm{K}, \mathrm{Ca}, \mathrm{Mg}\left(\mathrm{g} \mathrm{kg}^{-1}\right)$ e $\mathrm{Fe}, \mathrm{Mn}, \mathrm{Zn}$ e Cu $\left(\mathrm{mg} \mathrm{kg}^{-1}\right)$ na parte aérea e raizes.

- Teor de clorofila dos cultivares (valor SPAD 502). 
- Área foliar de cada cultivar em estudo $\left(\mathrm{cm}^{2}\right)$

- Número médio de perfilhos por planta.

\subsubsection{Delineamento experimental e analise estatística}

O delineamento experimental utilizado foi blocos casualizados, obedecendo o esquema fatorial, testando-se 2 genótipos de arroz (IAC 47 e IAC 1205), e 6 níveis de Fe na solução nutritiva $(0,125 ; 0,625 ; 1,25$; 12,$50 ; 25,00$, e $50,00 \mathrm{mg} \mathrm{L}^{-1}$ ), totalizando 12 tratamentos com 4 repetições por cada tratamento, considerando como unidade experimental cada recipiente contendo 18 plantas. A análise estatística dos parâmetros avaliados foi realizada segundo Gomes (1990), aplicando-se o Teste de F conforme a Tabela 3 de análise da variância.

Tabela 3. Análise da variância para interação genótipos e níveis de ferro

\begin{tabular}{lr}
\hline Causas de variação & G.L. \\
\hline Blocos & 3 \\
Genótipos & 1 \\
Níveis de Fe & 5 \\
Genótipos x níveis de Fe & 5 \\
Resíduo & 33 \\
\hline Total & 47 \\
\hline
\end{tabular}




\section{RESULTADOS E DISCUSSÃO}

4.1. Aspecto das plantas dos genótipos estudados.

Foi observado que na menor concentração de ferro na solução, na parte aérea das plantas de cada genótipo desenvolveram-se sintomas de deficiência a partir dos 15 dias de colocadas na soluçao nutritiva definitiva, acentuando-se com o tempo.

No final da experiência, antes da colheita das plantas, observou-se que os dois genótipos apresentaram crescimento normal no nível $0,125 \mathrm{mg} \mathrm{L}^{-1} \mathrm{de}$ ferro, apresentando raízes vigorosas, sadias e de coloração clara (Figura 25.a). Confirmando as informações de Shimada (1995), encontrou-se clorose internerval nas folhas jovens dos genótipos estudados na menor dose, sintomatologia característica de deficiência de ferro nas folhas de plantas de arroz, denominado por Mengel \& Kirkby (1987), reticulado fino das nervuras.

Esse amarelecimento entre as nervuras pode ser causado pela inibição da formação de clorofila, pois o ferro é requerido por enzimas que participam da 
biossintese da mesma, conforme Salisbury \& Ross (1991), e sendo o ferro um elemento relativamente imóvel no floema, este pode ser prejudicado em sua translocação a grandes distâncias, permanecendo precipitado nas nervuras das folhas, conforme citado por Taiz \& Zeiger (1991).

No nível $0,625 \mathrm{mg} \mathrm{L}^{-1}$ de ferro as plantas dos dois genótipos apresentaram um excelente crescimento, tanto da parte aérea como das raízes. (Figura 25.b)

No nível $1,25 \mathrm{mg} \mathrm{L}^{-1}$ praticamente não houve diferença do nível anterior, quanto a aspecto e crescimento das plantas (Figura 25.c). A deposição de ferro nas raizes começou a partir da dose $12,50 \mathrm{mg} \mathrm{L}^{-1}$, provocando uma coloração laranja ferruginosa, devido a precipitação do ferro sobre as mesmas, como citado por Bacha (1976) e Foy (1978) (Figura 25.d). Já no nível $25,0 \mathrm{mg} \mathrm{L}^{-1}$ de ferro, o cultivar IAC-47 apresentou diminuição no crescimento afetando mais a parte aérea que as raízes, sendo que observou-se nas mesmas um incremento da coloração ferruginosa (Figura 25.e). O genótipo IAC-1205 manifestou escassa redução no crescimento, e leve sintomatologia de toxidez por ferro nas folhas (Figura 24.b) Nas plantas do cultivar IAC-47 ao nível $50,0 \mathrm{mg} \mathrm{L}^{-1}$ de ferro na solução, houve grande redução do crescimento, afetando mais a parte aérea que as raízes, como resultados encontrados por Fageria (1984); a sintomatología de toxicidade nas folhas em presença das maiores doses neste genótipo, foi uma coloração laranja ou amarela nas folhas maduras, coincidindo com sintomas descritos na literatura (Figura 24.a; Figura 25.f)

Observou-se que as raízes nos níveis mais elevados de ferro na solução, apresentaram-se curtas e grossas, como relatado por Camargo \& Camargo (1985), e frequentemente de coloração bruno-escura, como apresentado nas Figuras 24.a-b; e Figuras 25.d-e-f. 
4.2. Efeito dos níveis de ferro sobre alguns parâmetros de crescimento, dos genótipos de arroz estudados.

\subsubsection{Efeito sobre a produção de matéria seca.}

Na Tabela 4 encontramos o peso do material seco da parte aérea $\left(\mathrm{g} \mathrm{planta}^{-1}\right)$ em função dos níveis de ferro estudados dentro de cada genótipo. É possivel observar que estes apresentaram diferente comportamento em relação aos níveis de ferro em solução nutritiva. Assim a matéria seca da parte aérea no genótipo IAC-47 aumentou até o nível $0,625 \mathrm{mg} \mathrm{L}^{-1}$, para diminuir posteriormente em função do incremento das doses de ferro. Entretanto, o IAC-1205 aumentou até o nível $12,50 \mathrm{mg} \mathrm{L}^{-1}$, reduzindo seu peso a partir da mesma, com leve incremento na maior dose.

Tabela 4. Peso da matéria seca da parte aérea $\left(\mathrm{g} \mathrm{planta}^{-1}\right)$, de dois genótipos de arroz, em função das doses estudadas de ferro na solução nutritiva.

\begin{tabular}{lcccccccc}
\hline & \multicolumn{7}{c}{ Fe (mg L $\left.{ }^{-1}\right)$} \\
Genótipos & 0,125 & 0,625 & 1,25 & 12,50 & 25,00 & 50,00 & Média \\
\hline IAC-47 & $12,4 \mathrm{aA}$ & $13,3 \mathrm{aA}$ & $11,6 \mathrm{aA}$ & $9,9 \mathrm{bA}$ & $8,1 \mathrm{aA}$ & $6,4 \mathrm{bB}$ & $10,2 \mathrm{aA}$ \\
IAC-1205 & $9,2 \mathrm{bB}$ & $9,8 \mathrm{bB}$ & $11,0 \mathrm{aA}$ & $12,4 \mathrm{aA}$ & $9,6 \mathrm{aA}$ & $10,9 \mathrm{aA}$ & $10,5 \mathrm{aA}$
\end{tabular}

* Médias seguidas por letras distintas, maiúsculas $\mathrm{P}<0,01$ e minúsculas $\mathrm{P}<0,05$, diferem entre si pelo teste de Tuckey.

O genótipo IAC-47 apresentou valores superiores ao IAC-1205 com diferenças estatísticas significativas $(\mathrm{P}<0,01)$ nas doses 0,125 e $0,625 \mathrm{mg} \mathrm{L}^{-1}$, não se observando diferenças nas doses 1,25 e $25,0 \mathrm{mg} \mathrm{L}^{-1}$, enquanto que na dose 50,0 o IAC-1205 apresentou diferencia significativa $(\mathrm{P}<0,01)$, superando ao IAC-47. 
Segundo os resultados da análise estatística, verificou-se interação significativa $(P<0,01)$ entre genótipos e concentração de ferro na solução em relação ao peso do material seco da parte aérea. Encontrou-se também efeitos significativos $(\mathrm{P}<0,01)$ entre as doses de ferro, mas não entre genótipos, considerando-se o parâmetro em questão.

O comportamento dos genótipos estudados em função dos níveis de ferro aplicados, é apresentado na Figura 1, na qual é encontrada a equação de regressão entre o peso do material seco da parte aérea $\left(g\right.$ planta $\left.^{-1}\right)$ e as doses de ferro (mg L $\left.{ }^{-1}\right)$ para o IAC-47. A regressão representa a variação do peso da parte aérea em função dos níveis de ferro, porém o IAC-47 ajustou-se a uma equação linear negativa, enquanto que dentro do IAC-1205 não houve relação entre doses de ferro e peso da matéria seca da parte aérea.

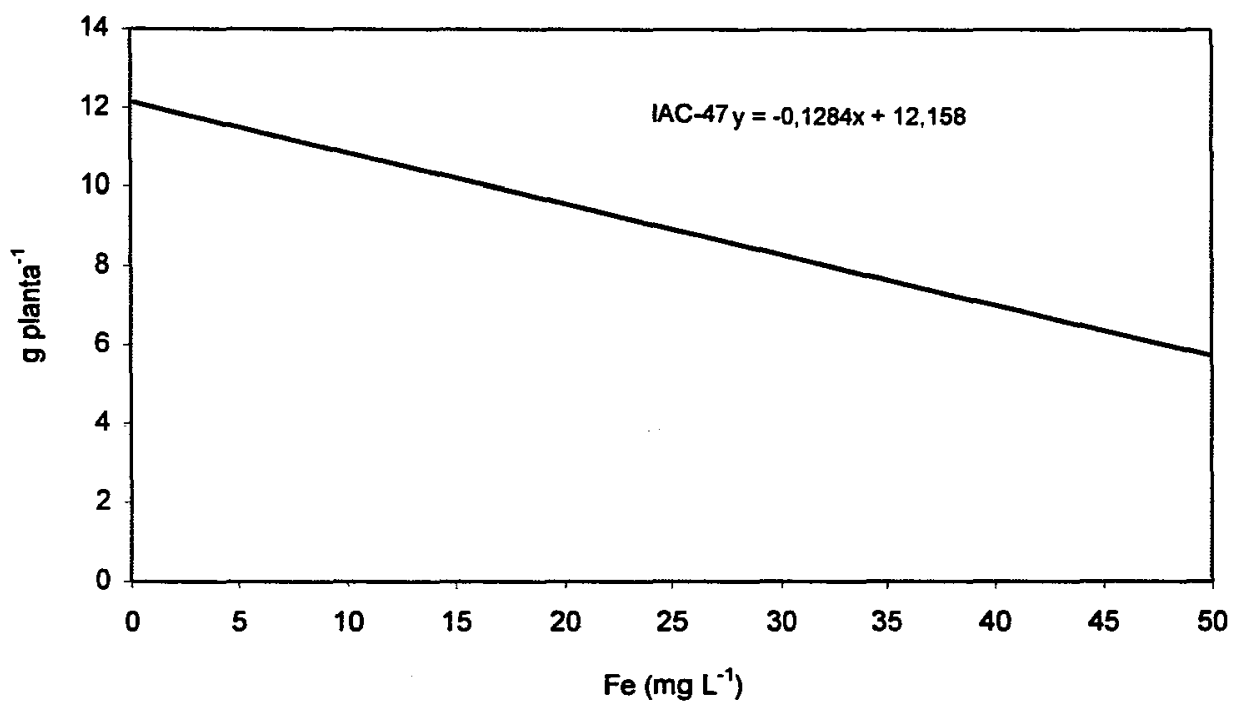

Figura 1. Relação entre a matéria seca da parte aérea de dois genótipos de arroz, em função dos niveis de Fe na solução. 
O peso do material seco das raizes ( $g$ planta $^{-1}$ ), em função dos níveis de ferro estudados ( $\left.\mathrm{mg} \mathrm{L}^{-1}\right)$ encontra-se na Tabela 5 . Observa-se que os genótipos apresentaram comportamentos diferentes em relação aos níveis de ferro. Com a adição das doses crescentes de ferro nas soluções, houve um efeito prejudicial no genótipo IAC-47 o qual apresentou sensível redução a partir da dose 0,625 $\mathrm{mg} \mathrm{L} \mathrm{L}^{-1}$.

Tabela 5. Peso da matéria seca das raizes $\left(\mathrm{g}_{\text {planta }}{ }^{-1}\right)$, de dois genótipos de arroz, em função das doses de ferro na solução nutritiva.

\begin{tabular}{lcccccccc}
\hline & \multicolumn{7}{c}{$\mathrm{Fe}\left(\mathrm{mg} \mathrm{L}^{-1}\right)$} \\
Genótipos & 0,125 & 0,625 & 1,25 & 12,50 & 25,00 & 50,00 & Média \\
\hline IAC-47 & $2,24 \mathrm{aA}$ & $2,46 \mathrm{aA}$ & $1,71 \mathrm{aA}$ & $1,19 \mathrm{bB}$ & $1,48 \mathrm{bA}$ & $1,06 \mathrm{bB}$ & $1,69 \mathrm{bB}$ \\
IAC-1205 & $1,57 \mathrm{bA}$ & $1,70 \mathrm{bB}$ & $1,95 \mathrm{aA}$ & $2,95 \mathrm{aA}$ & $2,05 \mathrm{aA}$ & $2,45 \mathrm{aA}$ & $2,11 \mathrm{aA}$
\end{tabular}

* Médias seguidas por letras distintas, maiúsculas $\mathrm{P}<0,01$ e minúsculas $\mathrm{P}<0,05$, diferem entre si pelo teste de Tuckey.

Os resultados da análise estatística mostraram, interação significativa $(\mathrm{P}<0,01)$ entre genótipos e concentração de ferro nas soluções em relação ao peso do material seco das raizes. Também foram encontrados efeitos altamente significativos $(\mathrm{P}<0,01)$ de genótipos, não para as concentrações de ferro nas soluções nutritivas.

O genótipo IAC-1205 apresentou incremento no peso do material seco das raízes conforme as doses crescentes de Fe nas soluções até o nível 12,50 $\mathrm{mg} \mathrm{\textrm {L } ^ { - 1 }}$, diminuindo na de $25,0 \mathrm{mg} \mathrm{L}^{-1}$, e apresentando um leve incremento novamente na dose $50 \mathrm{mg} \mathrm{L}^{-1}$. É possível observar que para o IAC-47 na dose $0,625 \mathrm{mg} \mathrm{L}^{-1}$, a produção de matéria seca na parte aérea foi superior estatisticamente ao IAC-1205 ao nível $\mathrm{P}<0,01$ de significância, já no nível 1,25 não se verificou diferença, e com adições de 12,50 e $25,0 \mathrm{mg} \mathrm{L}^{-1}$ de ferro, foi o IAC- 
1205 quem apresentou maior produção de matéria seca diferindo significativamente ao nível $\mathrm{P}<0,05$, enquanto que na maior dose $\left(50 \mathrm{mg} \mathrm{L}^{-1}\right)$ de $\mathrm{Fe}$ o IAC-1205 a significância foi a $\mathrm{P}<0,01$, dando-se em esta dose a maior diferença entre genótipos (Tabela 5). Verificou-se que o genótipo IAC-1205 foi o que apresentou maior tolerância à adição de doses crescentes de ferro nas soluções.

A relação do peso do material seco das raízes em cada genótipo, em função dos níveis de ferro aplicados, é apresentado na Figura 2, onde são representadas as equações de regressão entre o peso do material seco das raízes ( $g$ planta $\left.^{-1}\right)$ e as doses de ferro $\left(\mathrm{mg} \mathrm{L}^{-1}\right)$ para os genótipos em estudo. O IAC-47 apresentou redução do peso do material seco das raízes representado pela equação de segundo grau $(P<0,05)$, enquanto que no genótipo IAC-1205 a relação ajustouse a uma equação de segundo grau, aumentando o peso seco das raízes conforme incremento do nível de ferro nas soluções, e diminuindo na maior.

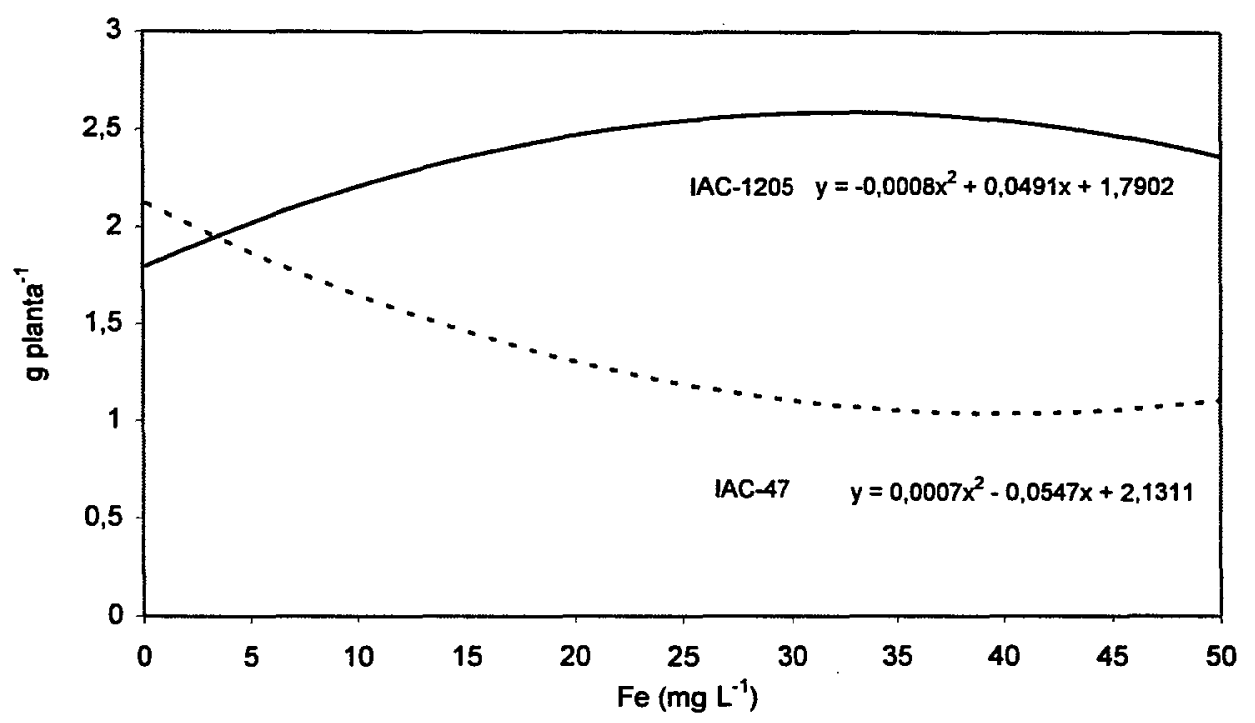

Figura 2. Relação entre a matéria seca das raizes de dois genótipos de arroz, e niveis de Fe na solução. 
Camargo (1984 ), encontrou resultados similares de redução do peso da parte aérea e raízes, conforme aumentava a concentração de ferro nas soluções a níveis altos (100 $\left.\mathrm{mg} \mathrm{L}^{-1}\right)$; nesse trabalho o genótipo de arroz que evidenciou maior tolerância a altas concentrações de ferro nas soluções apresentou maior produção de material seco das raízes quando comparado com outros genótipos testados. Fageria (1984), também encontrou redução da matéria seca da parte aérea e raízes, com variações entre cultivares, com diminuições significativas acima de $20 \mathrm{mg} \mathrm{L}^{-1}$ de ferro na solução.

Agarwala (1965), estudando ferro em plantas de cevada, encontrou aumentos na produção de matéria seca com aumentos desse micronutriente no substrato. Miller et.al. (1961), reportaram resultados semelhantes para produção de feijão. Twyman (1959), encontrou que o peso do material seco total diminuiu com baixas concentrações de ferro no substrato. Agarwala (1965), encontrou efeitos característicos de deficiência de ferro em milho causado por baixos níveis de ferro. A produção de matéria seca na parte aérea e raízes, e reposta dos genótipos a níveis de ferro obtidos neste experimento, estão em concordância com observações reportadas na bibliografia.

\subsubsection{Efeito sobre a área foliar}

A tabela 6 apresenta área foliar $\left(\mathrm{cm}^{2}\right)$ em função dos níveis de ferro estudados dentro de cada genótipo. Observa-se que na dose mínima de Fe na solução $\left(0,125 \mathrm{mg} \mathrm{L}^{-1}\right)$ a área foliar no genótipo IAC-47 foi superior estatisticamente $(P<0,01)$ ao genótipo IAC-1205. Nas doses 0,625 e $1,25 \mathrm{mg} \mathrm{L}^{-1}$ embora não se tenha encontrado diferença significativa, o IAC-47 apresentou 
valores maiores que o IAC-1205. Já na dose $12,50 \mathrm{mg} \mathrm{L}^{-1}$ sem diferença significativa encontrou-se que a área foliar do IAC-1205 foi maior que o IAC-47, e com adição de ferro na solução $\left(25,0\right.$ e $\left.50,0 \mathrm{mg} \mathrm{L}^{-1}\right)$ foi maior a área foliar do IAC1205 diferindo significativamente $(\mathrm{P}<0,01)$ do genótipo IAC-47.

Tabela 6. Área foliar $\left(\mathrm{cm}^{2}\right)$ de dois genótipos de arroz, em função dos níveis de ferro na solução nutritiva (média de quatro repetições).

\begin{tabular}{lcccccccc}
\hline & \multicolumn{7}{c}{$\mathrm{Fe}\left(\mathrm{mg} \mathrm{L}^{-1}\right)$} \\
Genótipos & 0,125 & 0,625 & 1,25 & 12,50 & 25,00 & 50,00 & Média \\
\hline IAC-47 & $758,2 \mathrm{aA}$ & $866,2 \mathrm{aA}$ & $672,2 \mathrm{aA}$ & $486,4 \mathrm{aA}$ & $471,1 \mathrm{bB}$ & $312,3 \mathrm{bB}$ & $594,5 \mathrm{bB}$ \\
IAC-1205 & $528,7 \mathrm{bB}$ & $771,9 \mathrm{aA}$ & $616,0 \mathrm{aA}$ & $540,2 \mathrm{aA}$ & $784,1 \mathrm{aA}$ & $\mathbf{8 8 8 , 5} \mathrm{aA}$ & $688,2 \mathrm{aA}$ \\
\hline
\end{tabular}

* Médias seguidas por letras distintas, maiúsculas $\mathrm{P}<0,01$ e minúsculas $\mathrm{P}<0,05$, diferem entre si pelo teste de Tuckey.

O comportamento de cada genótipo quanto a área foliar, em função dos níveis de Fe aplicados, é apresentado na Figura 3, onde são representadas as equações de regressão entre a área foliar $\left(\mathrm{cm}^{2}\right)$ e as doses de $\mathrm{Fe}\left(\mathrm{mg} \mathrm{L}^{-1}\right)$ para os genótipos estudados. Para o IAC-47 a regressão representa a redução da área foliar em função da adição de ferro na solução, ajustando-se a uma equação linear negativa $(\mathrm{P}<0,01)$, e para o genótipo IAC-1205 a regressão representa o aumento da área foliar conforme se aumenta a dose de Fe na solução nutritiva, apresentando incrementos segundo uma equação linear positiva $(\mathrm{P}<0,01)$. 


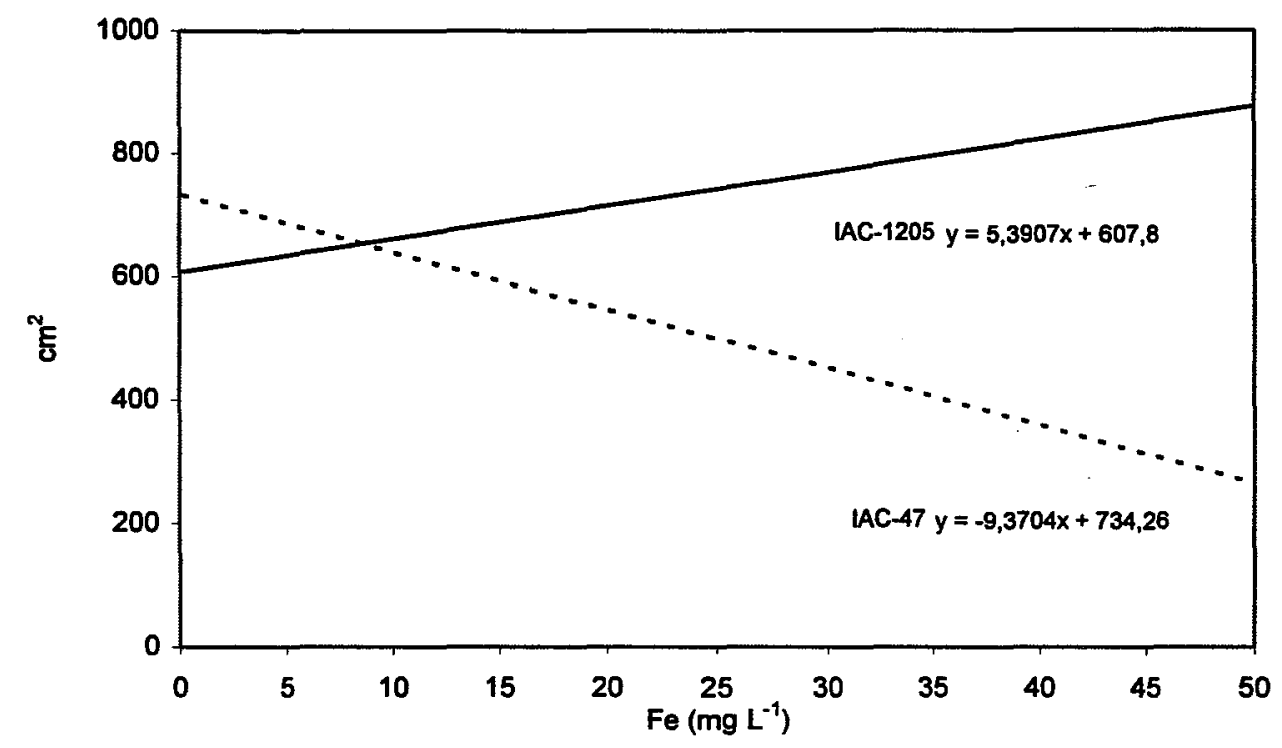

Figura 3. Relaçāo entre área foliar de dois genótipos de arroz, e niveis de ferro na solução.

Os resultados da análise estatística mostraram interação significativa entre genótipos e concentração de Fe nas soluções, considerando área foliar dos genótipos em estudo $(\mathrm{P}<0,01)$. Verificou-se também efeitos altamente significativos $(P<0,01)$ de genótipos e das concentrações de $F e$ nas soluções

Baseando-se nos resultados obtidos de área foliar é possível observar que o IAC-1205 é mais sensível que o IAC-47 a baixos níveis de Fe na solução, e mais tolerante a altas concentrações do mesmo.

Estes resultados poderiam estar indicando que o IAC-1205 é menos eficiente em absorver ferro da solução que o IAC-47, atingindo este último mais rapidamente uma concentração prejudicial para a planta, e comportando-se melhor a valores baixos de ferro, e pelo comportamento inverso do IAC-1205 observa-se que este não é muito prejudicado por níveis altos de Fe na solução, encontrando até incremento no valor do parâmetro na dose máxima $\left(50 \mathrm{mg} \mathrm{L}^{-1}\right)$. 
4.2.3. Efeito sobre a altura de planta e comprimento de raiz

A tabela 7 apresenta a altura de planta (cm) em função dos níveis de Fe estudados dentro de cada genótipo. Os resultados da análise estatística, mostraram pelo teste $F$, efeitos significativos $(\mathrm{P}<0,05)$ de genótipos e das concentrações de ferro nas soluções nutritivas. Não foram verificadas interações significativas entre genótipos e níveis de Fe na solução em relação a altura de planta. Fageria (1981), encontrou que até $40\left(\mathrm{mg} \mathrm{L}^{-1}\right)$, houve aumento na altura das plantas, enquanto que a partir de $80 \mathrm{mg} \mathrm{L}^{-1}$ de ferro na solução, provocou redução significativa na altura das plantas quando comparadas com concentrações menores.

Tabela 7. Altura de planta (cm), em função dos níveis de ferro na solução nutritiva, dentro de cada genótipo (média de quatro repetições).

\begin{tabular}{lccccccc}
\hline & \multicolumn{5}{c}{$\mathrm{Fe}\left(\mathrm{mg} \mathrm{L}^{-1}\right)$} \\
Genótipos & 0,125 & 0,625 & 1,25 & 12,50 & 25,00 & 50,00 & Média \\
\hline IAC-47 & 15,39 & 19,57 & 17,12 & 15,53 & 15,43 & 13,16 & $16,04 \mathrm{bA}$ \\
IAC-1205 & 16,25 & 18,81 & 17,77 & 15,71 & 17,84 & 18,96 & $17,56 \mathrm{aA}$ \\
\hline
\end{tabular}

* Médias seguidas por letras distintas, maiúsculas $\mathrm{P}<0,01$ e minúsculas $\mathrm{P}<0,05$, diferem entre si pelo teste de Tuckey.

Para o genótipo IAC-47 com a adição de doses crescentes de ferro nas soluções, houve aumento na dose $0,625 \mathrm{mg} \mathrm{L}^{-1}$, para posteriormente diminuir com incrementos dos níveis de Fe. O genótipo IAC-1205 apresentou valores mais elevados que o IAC-47 nas maiores concentrações de ferro, aumentando a diferença conforme aumentava a concentração até a dose máxima estudada $(50,0$ $\mathrm{mg} \mathrm{L}^{-1}$ ). Considerando estes resultados de altura de planta para cada genótipo, em 
função das doses de ferro na solução, é possivel observar que o IAC-47 é o mais prejudicado nas maiores doses, evidenciando menor tolerancia a altos níveis de ferro na solução.

A Tabela 8 mostra o comprimento médio de raizes $(\mathrm{cm})$ em função dos niveis de $\mathrm{Fe}$ estudados dentro de cada genótipo. Conforme os resultados da análise estatística pelo teste $F$, verificou-se interação significativa $P<0,01$ entre genótipos e concentrações de Fe nas soluções em relação a comprimento de raiz, encontrando-se também efeitos significativos de genótipos e das concentrações de ferro nas soluções nutritivas, $\mathrm{P}<0,05$ e $\mathrm{P}<0,01$ respectivamente.

Tabela 8. Comprimento de raiz $(\mathrm{cm})$, em função dos níveis de ferro na solução nutritiva, dentro de cada genótipo (média de quatro repetições).

\begin{tabular}{lccccccc}
\hline Genótipos & 0,125 & 0,625 & 1,25 & 12,50 & 25,00 & 50,00 & Média \\
\hline IAC-47 & $35,0 \mathrm{aA}$ & $38,3 \mathrm{aA}$ & $35,0 \mathrm{aA}$ & $30,5 \mathrm{aA}$ & $30,8 \mathrm{aA}$ & $26,5 \mathrm{aA}$ & $32,7 \mathrm{aA}$ \\
IAC-1205 & $27,0 \mathrm{bB}$ & $27,8 \mathrm{bB}$ & $25,3 \mathrm{bB}$ & $31,3 \mathrm{aA}$ & $33,5 \mathrm{aA}$ & $28,5 \mathrm{aA}$ & $28,9 \mathrm{bB}$ \\
\hline
\end{tabular}

* Médias seguidas por letras distintas, maiúsculas $\mathrm{P}<0,01$ e minúsculas $\mathrm{P}<0,05$, diferem entre si pelo teste de Tuckey.

Observa-se que nos primeiros níveis $\left(0,125 ; 0,625\right.$ e $\left.1,25 \mathrm{mg} \mathrm{L}^{-1}\right)$ foi maior o comprimento de raiz para o IAC-47 diferenciando-se significativamente $(P<0,01)$ do genótipo IAC-1205, não assim nos outros níveis $(12,5 ; 25,0$; e 50,0 $\mathrm{mg} \mathrm{L}^{-1}$ ) em que não houve diferença significativa.

O comportamento de cada genótipo quanto a comprimento de raiz, em função dos níveis de Fe estudados, é apresentado na Figura 4, onde são representadas as equações de regressão entre o comprimento médio de raiz $(\mathrm{cm})$ e as doses de $\mathrm{Fe}\left(\mathrm{mg} \mathrm{L}^{-1}\right)$ para os dois genótipos. É possível observar que o valor da variável no IAC-47 aumentou até a dose $\left(0,625 \mathrm{mg} \mathrm{L}^{-1}\right)$, diminuindo 
posteriormente conforme a adição de Fe na solução, representado pela equação de regressão linear negativa $(P<0,01)$. Enquanto que o IAC-1205 aumentou praticamente até o nível 25,0 com uma leve redução na dose $50 \mathrm{mg} \mathrm{L}^{-1}$, representada pela equação de regressão de segundo grau $(P<0,01)$.

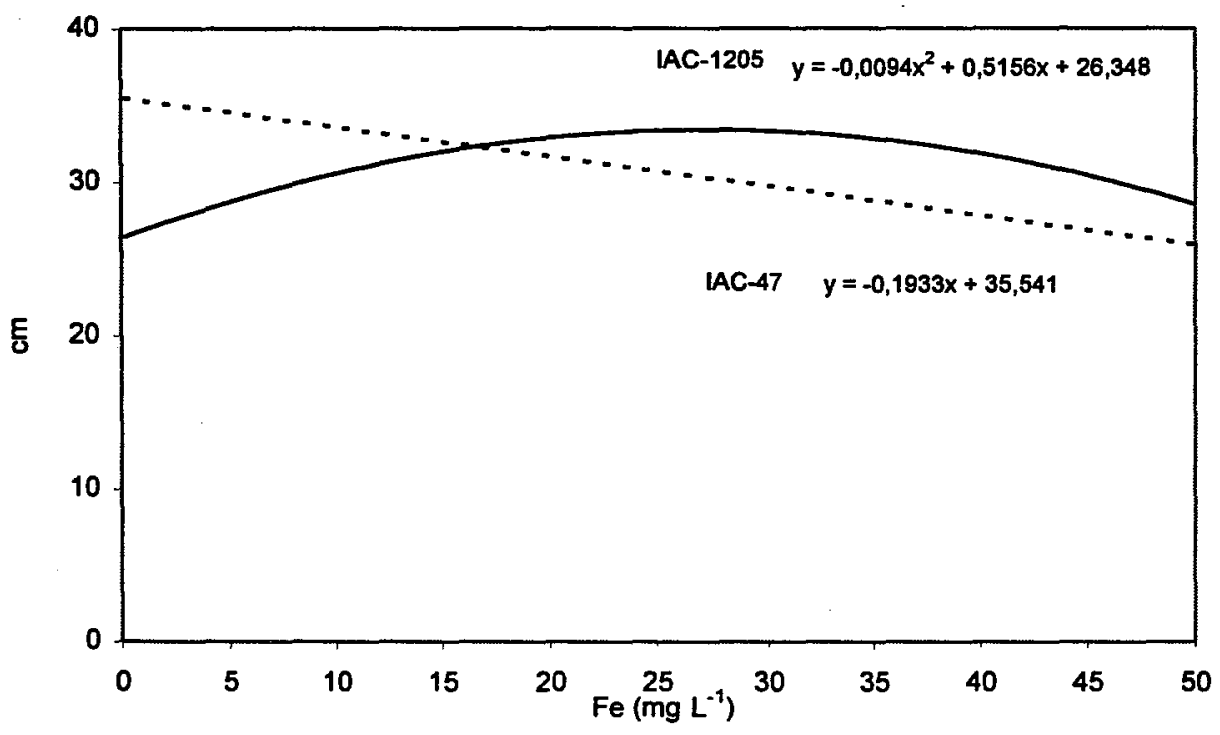

Figura 4. Relaçāo entre comprimento médio das raizes de dois genótipos de arroz, e doses de Fe na solução.

A variável comprimento de raízes, segundo Camargo (1984), não representa um parâmetro adequado para avaliar tolerância ao excesso de $\mathrm{Fe}$ nas soluções. Pelos resultados deste trabalho, o IAC-1205 que possivelmente seja o genótipo mais tolerante que o IAC-47 a altos níveis ferro em solução, pois apresentou valores de comprimento de raiz mais elevado, nas maiores doses de ferro. 
4.2.4. Efeito sobre o número de perfilhos

A Tabela 9 apresenta o número médio de perfilhos por planta em função dos níveis de ferro estudados ( $\left.\mathrm{mg} \mathrm{L}^{-1}\right)$, dentro de cada genótipo. Observase que os genótipos apresentaram comportamentos diferentes em relação aos níveis de Fe. Assim o IAC-47 mostrou redução progressiva no número de perfilhos, em função do aumento nos níveis de ferro na solução, já no IAC-1205 a adição de ferro na solução resultou em um aumento no número de perfilhos por planta.

Conforme os resultados da análise estatística, verificou-se interação significativa $\mathrm{P}<0,01$ entre genótipos e concentrações de $\mathrm{Fe}$ nas soluções em relação a número médio de perfilhos por planta, encontrando-se também efeitos significativos de genótipos $\mathrm{P}<0,01$.

Tabela 9. Número médio de perfilhos por planta de dois genótipos de arroz, em função dos níveis de ferro na solução nutritiva (média de quatro repetições).

\begin{tabular}{lccccccc}
\hline Genótipos & 0,125 & 0,625 & 1,25 & 12,50 & 25,00 & 50,00 & Média \\
\hline IAC-47 & $1,92 \mathrm{aA}$ & $1,77 \mathrm{aA}$ & $1,45 \mathrm{bB}$ & $1,37 \mathrm{bB}$ & $1,29 \mathrm{aA}$ & $1,67 \mathrm{bB}$ & $1,50 \mathrm{bB}$ \\
IAC-1205 & $1,67 \mathrm{aA}$ & $1,97 \mathrm{aA}$ & $2,15 \mathrm{aA}$ & $2,37 \mathrm{aA}$ & $1,60 \mathrm{aA}$ & $2,05 \mathrm{aA}$ & $1,97 \mathrm{aA}$ \\
\hline
\end{tabular}

* Médias seguidas por letras distintas, maiúsculas $\mathrm{P}<0,01$ e minúsculas $\mathrm{P}<0,05$, diferem entre si pelo teste de Tuckey.

O comportamento quanto ao número de perfilhos por planta no genótipo IAC-47 em função dos níveis de Fe aplicados, é apresentado na Figura 5, onde é representada a equação de regressão entre o número de perfilhos planta ${ }^{-1}$, e as doses de $\mathrm{Fe}\left(\mathrm{mg} \mathrm{L}^{-1}\right)$, para o citado genótipo, observando-se pela equação de regressão a diminuição do número de perfilhos em função dos níveis de ferro, com acentuada redução em função do aumento da concentração de ferro na solução, 
ajustando-se a uma equação linear descendente $(\mathrm{P}<0,01)$, enquanto no IAC-1205 não encontrou-se relação entre doses de ferro e genótipos para o número de perfilhos por planta, embora é possível observar que o número médio de perfilhos no genótipo IAC-1205 foi superior a do genótipo IAC-47. Resultados semelhantes foram encontrados por Fageria (1989), citando que a redução no número de perfilhos poderia ser um dos sintomas da toxicidade de ferro em arroz iirrigado.

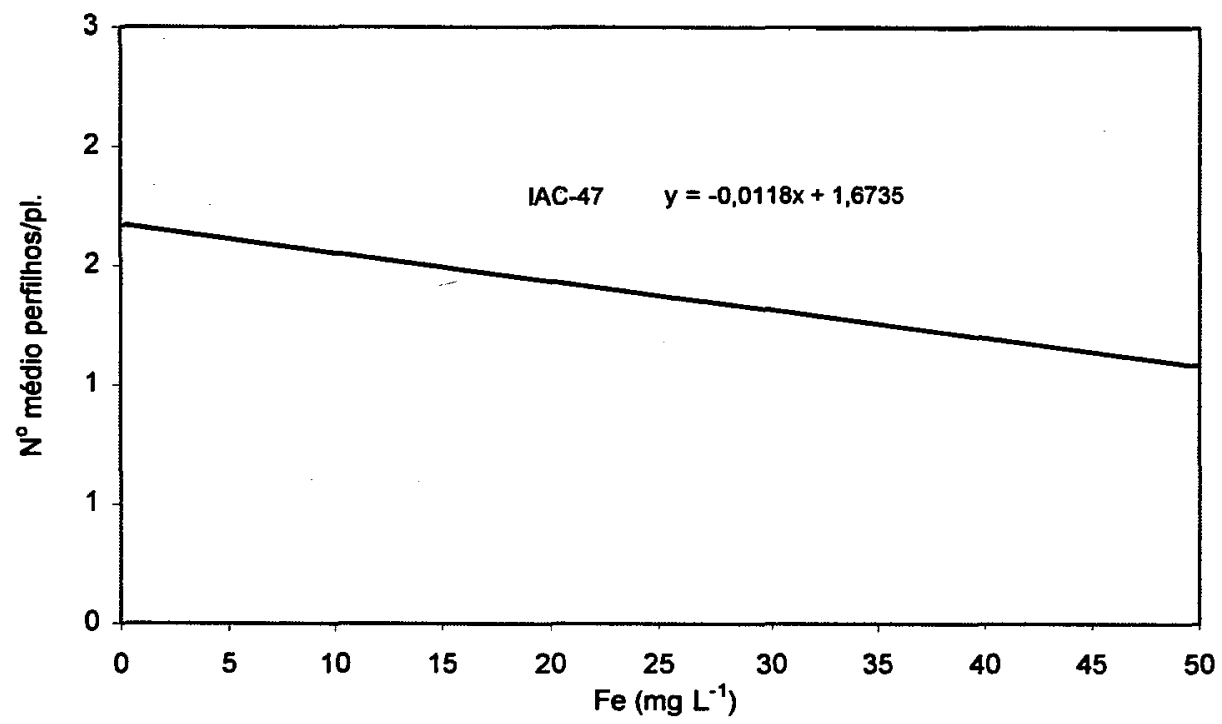

Figura 5. Relação entre o número médio de perfilhos planta ${ }^{-1}$ e os niveis de Fe na solução, para dois genótipos de arroz.

4.3. Efeito dos níveis de ferro sobre o teor de clorofila.

Os valores encontrados das leituras de clorofila são equivalentes aos obtidos por Peng et al. (1993), que realizaram determinações de clorofila (SPAD 
502) em plantas de arroz, utilizando o Chlorophyll meter's - SPAD 502 - Minolta.

Na Tabela 10, observa-se os valores de clorofila nas folhas (SPAD 502), em função dos níveis de ferro estudados dentro de cada genótipo; observa-se que os genótipos embora tenham todos apresentado incremento no valor de clorofila nas folhas com o aumento da concentração de $\mathrm{Fe}$ na solução, manifestaram valores diferentes conforme os genótipos. Assim, o genótipo IAC1205 apresentou valores de clorofila menores que o IAC-47.

Tabela 10. Leitura de clorofila (SPAD 502), em dois genótipos de arroz, em função dos níveis de ferro na solução nutritiva.

\begin{tabular}{lccccccc}
\hline & \multicolumn{5}{c}{$\mathrm{Fe}\left(\mathrm{mg} \mathrm{L}^{-1}\right)$} \\
Genótipos & 0,125 & 0,625 & 1,25 & 12,50 & 25,00 & 50,00 & Média \\
\hline IAC-47 & 41,70 & 44,10 & 44,00 & 43,90 & 45,90 & 45,60 & 44,22 aA \\
IAC-1205 & 39,40 & 41,80 & 42,30 & 42,80 & 43,20 & 44,50 & 42,36 bB \\
\hline
\end{tabular}

* Médias seguidas por letras distintas, maiúsculas $\mathrm{P}<0,01$ e minúsculas $\mathrm{P}<0,05$, diferem entre si pelo teste de Tuckey.

A interação genótipos e dose de Ferro considerando a clorofila como variável não foi significativa, embora encontrou-se diferença significativa $(\mathrm{P}<0,01)$ das doses de ferro e dos genótipos estudados.

O comportamento dos genótipos estudados quanto ao teor de clorofila (SPAD 502) nas folhas, em função dos níveis de ferro aplicados, é apresentado na Figura 6, onde está representada a equação de regressão entre o valor de clorofila das folhas e as doses de $\mathrm{Fe}\left(\mathrm{mg} \mathrm{L}^{-1}\right)$ para os dois genótipos. A regressão representa o aumento do valor de clorofila das folhas em função dos níveis de $\mathrm{Fe}$, porém os genótipos IAC-47 e IAC-1205 apresentaram aumentos segundo uma equação linear positiva. Estes resultados confirmam os obtidos por diversos autores como O'Sullivan (1969), que em seu experimento de efeito de $\mathrm{Fe}$ 
em espécies de gramíneas, encontrou incremento no teor de clorofila conforme aumentava o Ferro na solução de 0,04 para $2,56 \mathrm{mg} \mathrm{L}^{-1}$.

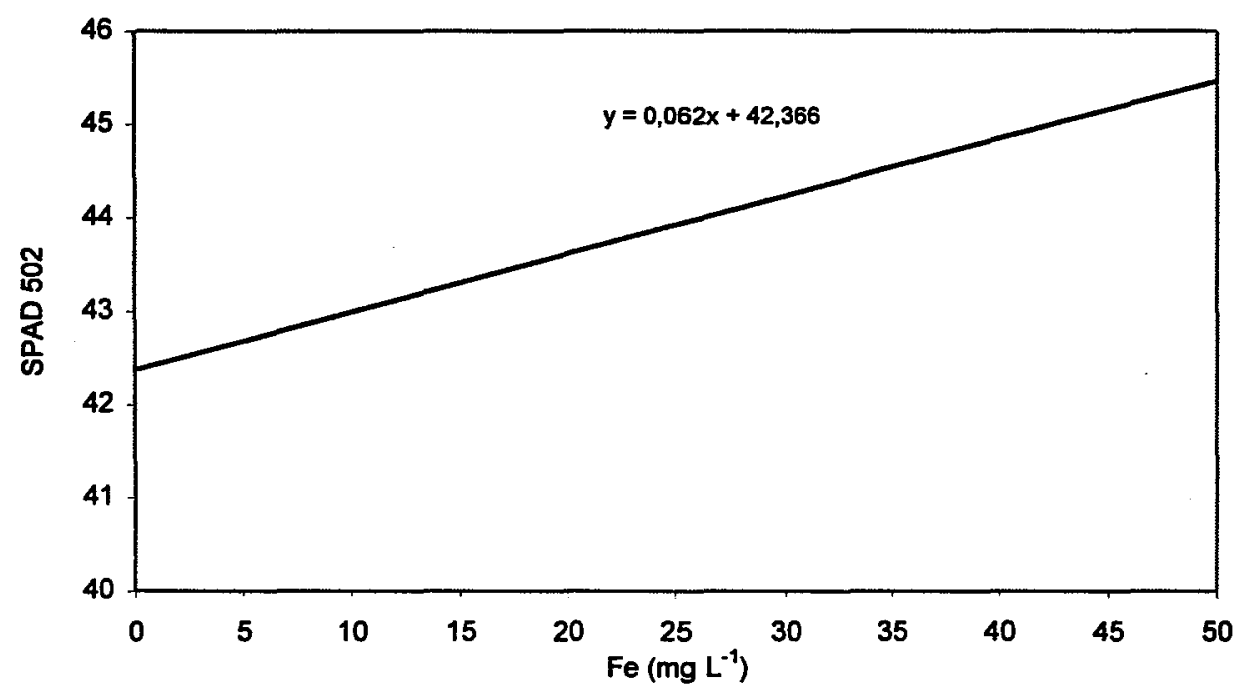

Figura 6. Relação entre a leitura de clorofila dos genótipos de arroz em estudo e doses de Fe na solução nutritiva.

A adição de ferro às soluções nutritivas influenciou na concentração de clorofila nos genótipos estudados, aumentando nas maiores doses a 1,13 e 1,09 vezes mais clorofila no IAC-1205 e IAC-47, respectivamente, quando comparada com a menor dose de ferro. Yunusa (1980), encontrou que plantas de sorgo crescendo em solos com adequada concentração de ferro geralmente continham 2,1 a 1,4 vezes mais clorofila total que plantas crescendo em solos deficientes em ferro, concordando com Sideris \& Yung (1956) que encontraram que a concentração total de clorofila nas folhas de abacaxi foi 2,2 vezes maior em plantas crescendo com concentrações adequadas de ferro que plantas deficientes nesse elemento. Shetty \& Miller (1966) encontraram diminuição de 45 \% no nível de clorofila em tecidos deficientes em ferro quando comparado a um tecido normal. 
Uma acentuada relação entre o fornecimento de ferro e teor de clorofila em espécies forrageiras foi encontrado por O'Sullivan (1969). Agarwala et.al. (1965), determinaram uma relação linear entre clorofila e fornecimento de ferro em milho, acima de uma concentração de 0,5 $\mu \mathrm{M}$ Fe. Marsh et.al. (1963), relataram que a deficiência de ferro em caupi, provocou limitada formação de ácido $\delta$ aminolevulínico, que é o precursor da biosíntese da molécula de clorofila. Segundo trabalhos de Terry (1980), o estresse de ferro provocou diminuição no teor de clorofila a - b, caroteno e xantofila nas folhas de Beta vulgaris $\mathrm{L}$.

4.4. Efeito de níveis de ferro na solução nutritiva sobre a concentração de alguns macronutrientes, nos genótipos de arroz estudados.

\subsubsection{Nitrogênio na parte aérea e raízes.}

A Tabela 11 apresenta as concentrações de nitrogênio na matéria seca da parte aérea $\left(\mathrm{g} \mathrm{kg}^{-1}\right)$ em função dos níveis de ferro estudados $\left(\mathrm{mg} \mathrm{L}^{-1}\right)$, dentro de cada genótipo. Observa-se que os genótipos apresentaram comportamentos diversos em relação aos níveis de Fe. Assim entre os genótipo IAC-47 e IAC-1205 não se verificou diferenças significativas nos níveis 0,$625 ; 1,25$ e $50,0 \mathrm{mg} \mathrm{L}^{-1}$, enquanto que para o IAC-47 na dose 0,125 a concentração de nitrogênio foi menor significativamente $(\mathrm{P}<0,01)$, apresentando diferenças significativa na dose 25,0 $\mathrm{mg} \mathrm{L}^{-1}(\mathrm{P}<0,01)$. 
Tabela 11. Concentração de nitrogênio $\left(\mathrm{g} \mathrm{kg}^{-1}\right)$ na matéria seca da parte aérea, de dois genótipos de arroz, em função das doses de $\mathrm{Fe}$ na solução nutritiva.

\begin{tabular}{lccccccc}
\hline Genótipos & 0,125 & 0,625 & 1,25 & 12,50 & 25,00 & 50,00 & Média \\
\hline IAC-47 & $28,7 \mathrm{bB}$ & $30,1 \mathrm{aA}$ & $31,6 \mathrm{aA}$ & $30,9 \mathrm{aA}$ & $34,0 \mathrm{aA}$ & $32,4 \mathrm{aA}$ & $31,27 \mathrm{aA}$ \\
IAC-1205 & $36,5 \mathrm{aA}$ & $31,1 \mathrm{aA}$ & $29,8 \mathrm{aA}$ & $27,8 \mathrm{bA}$ & $29,9 \mathrm{bB}$ & $32,5 \mathrm{aA}$ & $31,27 \mathrm{aA}$ \\
\hline
\end{tabular}

* Médias seguidas por letras distintas, maiúsculas $\mathrm{P}<0,01$ e minúsculas $\mathrm{P}<0,05$, diferem entre si pelo teste de Tuckey.

O genótipo IAC-47 apresentou tendencia de aumento na concentração de nitrogênio conforme aumentou-se a dose de Fe na solução até o nível $25,0 \mathrm{mg} \mathrm{L}^{-1}$, diminuindo na maior dose $\left(50,0 \mathrm{mg} \mathrm{L}^{-1}\right)$. $\mathrm{O}$ aumento no teor de nitrogênio nas plantas provocado pela a adição de ferro na solução, também foi encontrado por Melo Bastos (1993), em arroz. A concentração de nitrogênio no genótipo IAC-1205 diminuiu até a dose $12,50\left(\mathrm{mg} \mathrm{L}^{-1}\right)$ de ferro na solução, incrementando logo a doses maiores.

O comportamento da concentração de nitrogênio na matéria seca da parte aérea de cada genótipo em função dos níveis de ferro aplicados, é apresentado na Figura 7, onde são representadas as equações de regressão entre a concentração de nitrogênio na parte aérea e as doses de ferro aplicadas. Assim no genótipo IAC-47 a relação ajustou-se a uma equação de segundo grau $(\mathrm{P}<0,05)$, com aumento nas primeiras doses e posterior diminuição nas doses maiores, enquanto que no IAC-1205 foi representado também por uma equação de segundo grau $(\mathrm{P}<0,01)$, com máximo valor na menor dose de ferro $\left(0,125 \mathrm{mg} \mathrm{L}^{-1}\right)$, aumentando logo conforme as doses. Segundo a análise estatística encontrou-se diferença entre níveis de ferro $(\mathrm{P}<0,01)$, mas não entre genótipos, para a variável concentração de nitrogênio. 
As concentrações de nitrogênio na matéria seca da parte aérea, nos dois genótipos estudados encontraram-se dentro daqueles citados por Fageria et al (1995), como concentração adequada para a cultura do arroz, em estádio de perfilhamento.

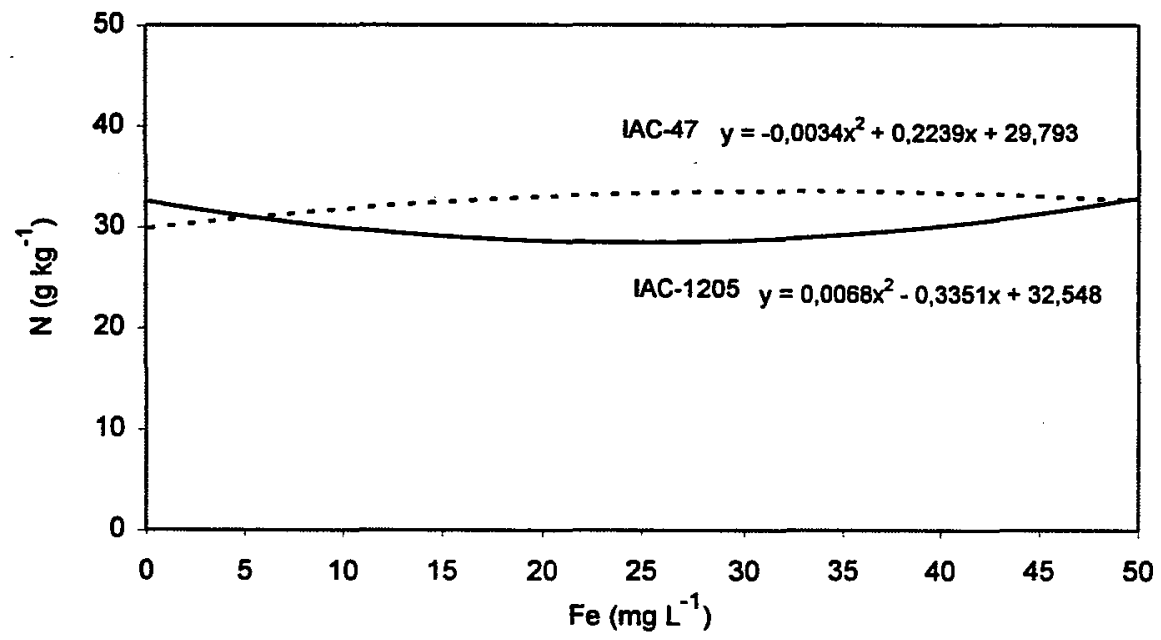

Figura 7. Relação entre concentração de nitrogênio na matéria seca da parte aérea de dois genótipos de arroz e doses de Fe na solução

São apresentadas na Tabela 12 as concentrações de nitrogênio na matéria seca das raízes em função dos níveis de ferro estudados dentro de cada genótipo. Observa-se que os genótipos apresentaram comportamentos diferentes em relação aos níveis de ferro, obedecendo uma distribuição semelhante à parte aérea, portanto no IAC-47 aumentou conforme foi incrementada a dose de ferro na solução até o nível $12,5 \mathrm{mg} \mathrm{L}^{-1}$, diminuindo posteriormente com aumento das doses de ferro. Enquanto que no IAC-1205 a concentração de nitrogênio nas raízes, em geral diminuiu conforme aumentou-se as doses de ferro. 
Tabela 12. Concentração de nitrogênio $\left(\mathrm{g} \mathrm{kg}^{-1}\right)$ na matéria seca das raízes, de dois genótipos de arroz, em função das doses de ferro na solução nutritiva.

\begin{tabular}{lccccccc}
\hline Genótipos & 0,125 & 0,625 & 1,25 & 12,50 & 25,00 & 50,00 & Média \\
\hline IAC-47 & $19,6 \mathrm{bB}$ & $21,1 \mathrm{aA}$ & $21,7 \mathrm{aA}$ & $23,7 \mathrm{aA}$ & $20,7 \mathrm{aA}$ & $19,2 \mathrm{aA}$ & $21,0 \mathrm{aA}$ \\
IAC-1205 & $22,7 \mathrm{aA}$ & $21,7 \mathrm{aA}$ & $20,4 \mathrm{bA}$ & $18,6 \mathrm{bB}$ & $19,2 \mathrm{bA}$ & $20,0 \mathrm{aA}$ & $20,4 \mathrm{bA}$ \\
\hline
\end{tabular}

* Médias seguidas por letras distintas, maiúsculas $\mathrm{P}<0,01$ e minúsculas $\mathrm{P}<0,05$, diferem entre si pelo teste de Tuckey.

Encontrou-se maiores concentrações de nitrogênio no IAC-47 a partir do nível 1,25 , diferindo significativamentè nesta e na dose $25\left(\mathrm{mg} \mathrm{L}^{-1}\right)(\mathrm{P}<0,05)$, já na dose 12,50 de ferro a diferença foi ao nível $\mathrm{P}<0,01$ de significância, sendo que a concentração de nitrogênio nas raízes foi significativamente maior no IAC-1205 na dose $0,125(\mathrm{P}<0,01)$. Não apresentando diferença significativa nas doses $0,625 \mathrm{e}$ $50,0 \mathrm{mg} \mathrm{L}^{-1}$.

Os resultados da análise estatística, mostraram interação altamente significativa $(\mathrm{P}<0,01)$ entre os dois genótipos e níveis de ferro nas soluções em relação à concentração de nitrogênio. Também foram verificados efeitos altamente significativos de doses de ferro $(\mathrm{P}<0,01)$, e significativos $(\mathrm{P}<0,05)$ de genótipos para a concentração de nitrogênio nas raízes.

O comportamento da concentração de nitrogênio na matéria seca das raízes em cada genótipo, em função dos níveis de ferro aplicados, é apresentado na Figura 8, na qual são representadas as equações de regressão entre a concentração de nitrogênio nas raizes e as doses de ferro, para os genótipos estudados. Assim a relação no cultivar IAC-47 ajustou-se a uma equação de segundo grau, com máximo na dose $12,5 \mathrm{mg} \mathrm{L}^{-1}$ e mínimo na menor e maior dose $\left(0,125\right.$ e $50,0 \mathrm{mg} \mathrm{L}^{-1}$ respectivamente). Enquanto que no genótipo IAC-1205 ajustou-se a uma equação de segundo grau invertida, com valor mínimo na dose $12,5 \mathrm{mg} \mathrm{L}^{-1}$. 
A diferença na concentração de nitrogênio nos dois genótipos poderia ser devido a um menor crescimento apresentado pelas plantas do IAC-47 conforme a adição ferro na solução, podendo ter promovido uma maior concentração de nitrogênio na parte aérea e raizes, concordando com resultados obtidos por Melo Bastos (1993), trabalhando com arroz.

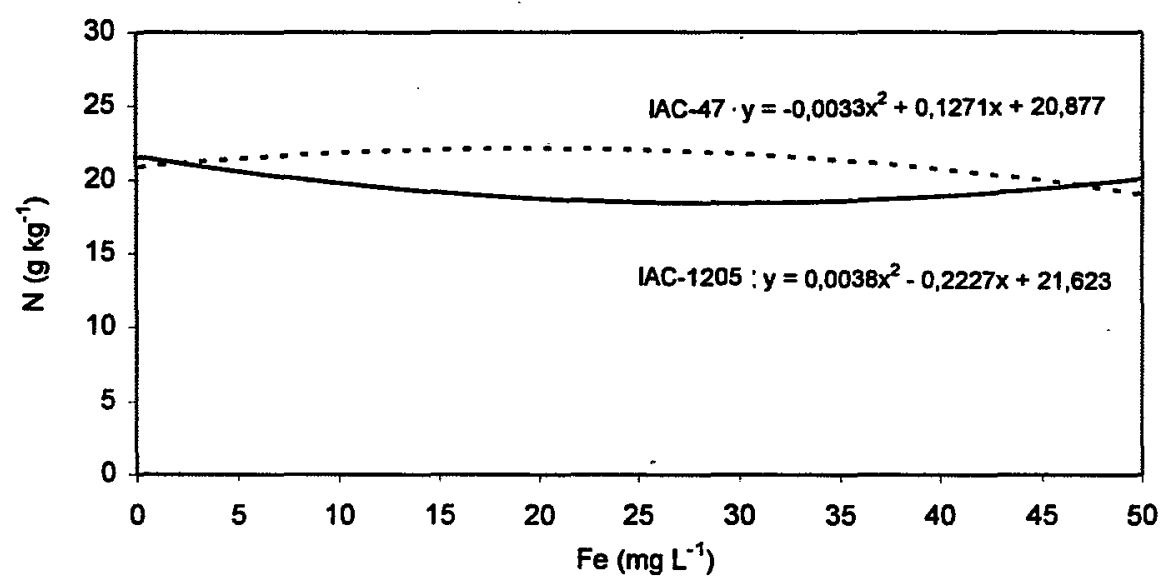

Figura 8. Relação entre concentração de nitrogênio na matéria seca das raizes de dois genótipos de arroz e doses de Fe na solução.

4.4.2. Fósforo na parte aérea e raízes.

A Tabela 13 apresenta a concentração de fósforo na matéria seca da parte aérea $\left(\mathrm{g} \mathrm{kg}^{-1}\right)$ em função dos níveis de ferro estudados $\left(\mathrm{mg} \mathrm{L}^{-1}\right)$ dentro de cada genótipo. Observa-se que os dois genótipos estudados apresentaram comportamento diferente quanto às doses de ferro na solução e concentração de fósforo na matéria seca da parte aérea, diferenciando-se o IAC-47 significativamente $(\mathrm{P}<0,01)$ do IAC-1205 na menor dose $0,125 \mathrm{mg} \mathrm{L}^{-1}$, apresentando concentrações menores de fósforo. Não houve diferença significativa entre os genótipos nas outras doses crescentes de ferro na solução. 
Tabela 13. Concentração de fósforo $\left(\mathrm{g} \mathrm{kg}^{-1}\right)$ na matéria seca da parte aérea, de dois genótipos de arroz, em função das doses de Fe na solução nutritiva.

\begin{tabular}{lccccccc}
\hline & \multicolumn{5}{c}{$\mathrm{Fe}\left(\mathrm{mg} \mathrm{L}^{-1}\right)$} \\
Genótipos & 0,125 & 0,625 & 1,25 & 12,50 & 25,00 & 50,00 & Média \\
\hline IAC-47 & $6,25 \mathrm{bB}$ & $7,05 \mathrm{aA}$ & $6,95 \mathrm{aA}$ & $\mathbf{8 , 4 0} \mathrm{aA}$ & $7,38 \mathrm{aA}$ & $4,45 \mathrm{aA}$ & $6,74 \mathrm{aA}$ \\
IAC-1205 & $9,15 \mathrm{aA}$ & $7,80 \mathrm{aA}$ & $\mathbf{8 , 2 8} \mathrm{aA}$ & $7,23 \mathrm{aA}$ & $6,15 \mathrm{aA}$ & $4,48 \mathrm{aA}$ & $7,18 \mathrm{aA}$ \\
\hline
\end{tabular}

* Médias seguidas por letras distintas, maiúsculas $\mathrm{P}<0,01$ e minúsculas $\mathrm{P}<0,05$, diferem entre si pelo teste de Tuckey.

Os valores de fósforo encontrados no IAC-47 aumentaram conforme incrementou-se a dose de ferro na solução até o nível 12,5, e diminuiram com doses superiores. Enquanto que no IAC-1205 diminuiu em função do aumento de ferro na solução.

Os resultados da análise estatística mostraram, interação altamente significativa $(P<0,01)$ entre genótipos e concentração de ferro nas soluções, em relação aos valores de fósforo encontrados na parte matéria seca da parte aérea. Foram verificados efeitos altamente significativos $(\mathrm{P}<0,01)$ de dose, não assim de genótipos em que não houve diferença significativa.

Na Figura 9 é apresentado o comportamento da concentração de fósforo na matéria seca da parte aérea em cada genótipo, em função dos níveis de ferro aplicados, na mesma são representadas as equações de regressão entre a concentração de fósforo na parte aérea e os níveis de ferro para cada genótipo. $O$ IAC-47 apresentou valores ajustando-se a uma equação de segundo grau $(P<0,01)$, com mínimo valor na maior dose $\left(50 \mathrm{mg} \mathrm{L}^{-1}\right)$ e máximo na dose $12,50 \mathrm{mg} \mathrm{L}^{-1}$. Enquanto que a regressão para o IAC-1205 representa a redução da concentração de fósforo na parte aérea em função dos níveis crescentes de ferro na solução, ajustada pela equação de regressão linear negativa $(\mathrm{P}<0,01)$. 


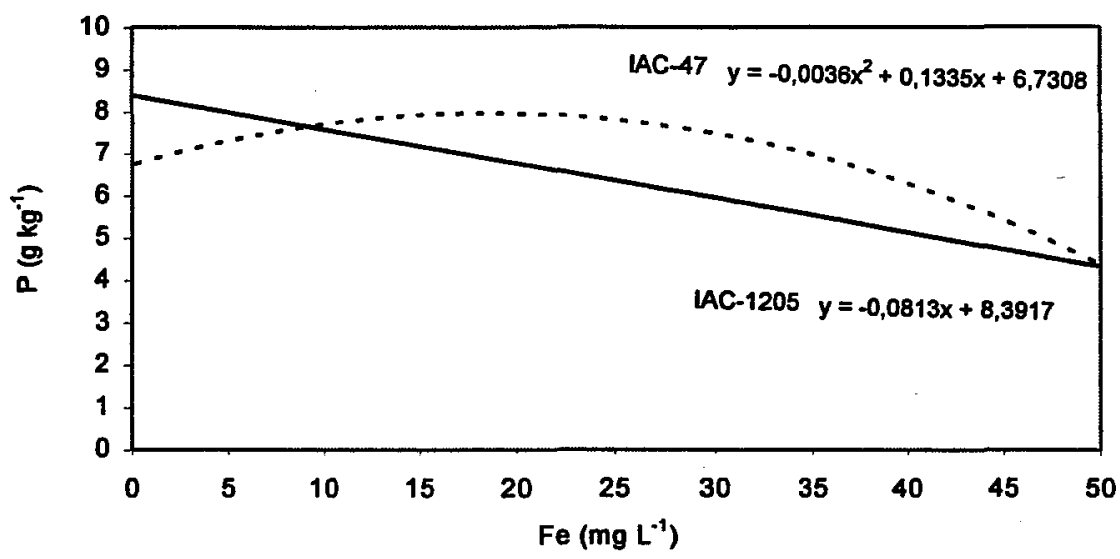

Figura 9. Relaçăo entre concentraçăo de fósforo na matéria seca da parte aérea de dois genótipos de arroz e doses de Fe na solução.

É apresentada na Tabela 14 a concentração de fósforo na matéria seca das raízes $\left(\mathrm{g} \mathrm{kg}^{-1}\right)$ em função dos níveis de ferro estudados $\left(\mathrm{mg} \mathrm{L}^{-1}\right)$ dentro de cada genótipo. Os dois genótipos apresentaram comportamentos semelhantes, verificando incrementos da concentração de fósforo nas raízes em função do aumento da dose de ferro na solução, e diminuindo na maior dose de ferro. Quando comparados os genótipos estudados, estes não diferiram significativamente nos três primeiros níveis de ferro $\left(0,125 ; 0,625\right.$ e $\left.1,25 \mathrm{mg} \mathrm{L}^{-1}\right)$, entretanto encontrou-se diferença significativa nos outros níveis $(12,5 ; 25,0$ e 50,0 $\mathrm{mg} \mathrm{L} \mathrm{L}^{-1}$ ), apresentando o IAC-47 concentrações maiores de fósforo na matéria seca das raízes.

Tabela 14. Concentração de fósforo $\left(\mathrm{g} \mathrm{kg}^{-1}\right)$ na matéria seca das raízes, de dois genótipos de arroz, em função das doses de ferro na solução nutritiva.

\begin{tabular}{lccccccc}
\hline & \multicolumn{5}{c}{$\mathrm{Fe}\left(\mathrm{mg} \mathrm{L}^{-1}\right)$} \\
Genótipos & 0,125 & 0,625 & 1,25 & 12,50 & 25,00 & 50,00 & Média \\
\hline IAC-47 & $3,88 \mathrm{aA}$ & $4,38 \mathrm{aA}$ & $4,88 \mathrm{aA}$ & $22,35 \mathrm{aA}$ & $21,73 \mathrm{aA}$ & $28,20 \mathrm{aA}$ & $14,23 \mathrm{aA}$ \\
IAC-1205 & $4,38 \mathrm{aA}$ & $4,78 \mathrm{aA}$ & $5,10 \mathrm{aA}$ & $11,10 \mathrm{bB}$ & $15,68 \mathrm{bA}$ & $16,03 \mathrm{bB}$ & $9,51 \mathrm{bB}$
\end{tabular}

* Médias seguidas por letras distintas, maiúsculas $\mathrm{P}<0,01$ e minúsculas $\mathrm{P}<0,05$, diferem entre si pelo teste de Tuckey. 
Segundo os resultados da análise estatística pelo teste $\mathrm{F}$, encontrou-se interação significativa $(P<0,01)$ entre genótipos e concentração de ferro na solução em relação ao valor de fósforo nas raízes, verificando também diferença significativa $(\mathrm{P}<0,01)$ das doses e dos genótipos.

O comportamento da concentração de fósforo nas raízes em cada genótipo em função dos niveis de ferro aplicados, é apresentado na Figura 10, onde são representadas as equações de regressão para cada genótipo. Os dois genótipos estudados apresentaram comportamento ajustado à equação de segundo grau $(P<0,01)$, verificando aumento no valor da concentração de fósforo nas raízes dos dois genótipos, conforme foi incrementado o nivel de ferro na solução, diminuindo esse incremento nas maiores doses.

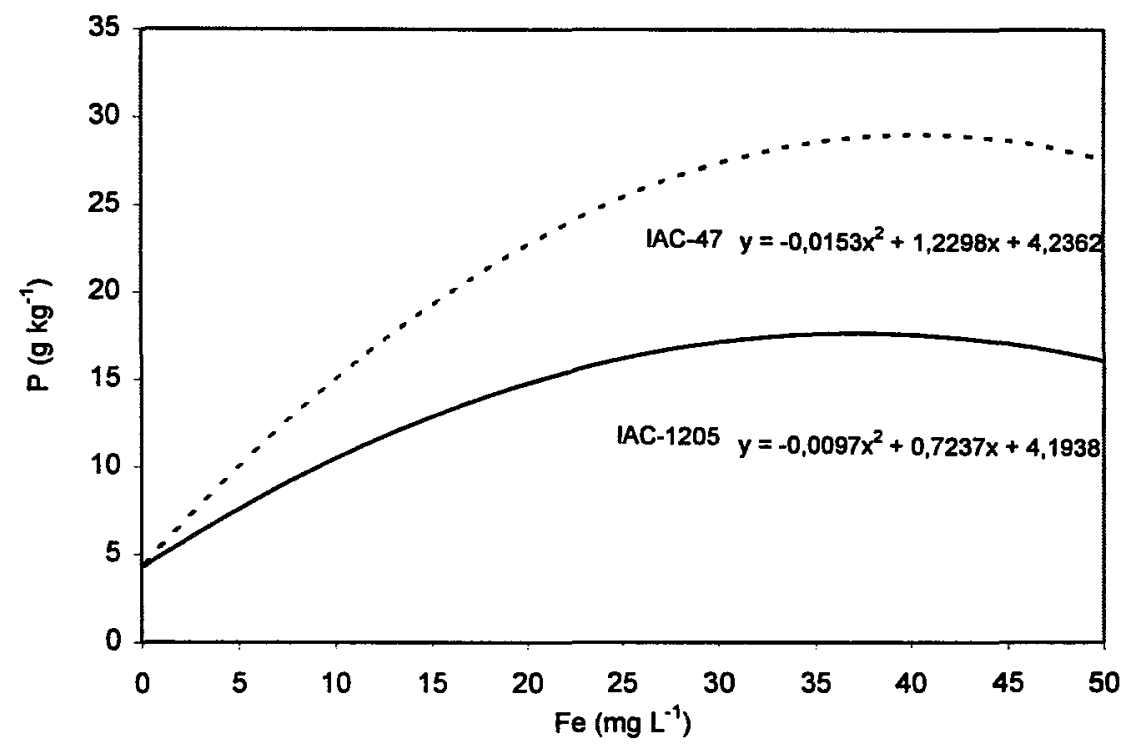

Figura 10. Relação entre concentração de fósforo na matéria seca das raizes de dois genótipos de arroz e doses de Fe na solução.

Pelos resultados obtidos é possível observar que até o nível 12,50 $m g L^{-1}$ de ferro na solução, a relação encontrada entre a concentração de fósforo e 
de ferro encontra-se nos valores normais para a cultura (29:1), conforme Jones (1991), diminuindo a mesma conforme posteriores aumentos de ferro.

As concentrações de fósforo na matéria seca da parte aérea e raízes, em geral apresentaram tendencia de diminuição nas maiores doses de ferro na solução, confirmando resultados obtidos por Fageria et al. (1981), e que segundo Howeler (1973) poderia ser explicado devido a que excesso de ferro no meio de crescimento pode bloquear a absorção de nutrientes através da camada de óxido férrico formado no sistema radicular.

\subsubsection{Potássio na parte aérea e raízes.}

Na Tabela 15 observa-se a concentração de potássio na matéria seca da parte aérea $\left(\mathrm{g} \mathrm{kg}^{-1}\right)$ em função dos níveis de ferro estudados $\left(\mathrm{mg} \mathrm{L}^{-1}\right)$ dentro de cada genótipo. Com a adição de doses crescentes de ferro nas soluções houve aumento na concentração de potássio no genótipo IAC-47 até a dose $12,5 \mathrm{mg} \mathrm{L}^{-1}$, com posterior diminuição do valor nas maiores doses; enquanto que no genótipo IAC-1205 diminuiu até a dose $1,25 \mathrm{mg} \mathrm{L}^{-1}$, aumentando logo até a dose $25,0 \mathrm{e}$ diminuindo na maior dose $\left(50 \mathrm{mg} \mathrm{L}^{-1}\right)$.

Tabela 15. Concentração de potássio $\left(\mathrm{g} \mathrm{kg}^{-1}\right)$ na matéria seca da parte aérea, de dois genótipos de arroz, em função das doses de ferro na solução nutritiva.

\begin{tabular}{lccccccc}
\hline & \multicolumn{5}{c}{$\mathrm{Fe}\left(\mathrm{mg} \mathrm{L}^{-1}\right)$} \\
Genótipos & 0,125 & 0,625 & 1,25 & 12,50 & 25,00 & 50,00 & Média \\
\hline IAC-47 & $34,1 \mathrm{aA}$ & $27,9 \mathrm{bB}$ & $36,1 \mathrm{aA}$ & $49,1 \mathrm{aA}$ & $44,1 \mathrm{aA}$ & $42,9 \mathrm{aA}$ & $39,0 \mathrm{aA}$ \\
IAC-1205 & $38,3 \mathrm{aA}$ & $38,0 \mathrm{aA}$ & $30,8 \mathrm{aA}$ & $34,2 \mathrm{bB}$ & $38,3 \mathrm{aA}$ & $35,4 \mathrm{aA}$ & $35,8 \mathrm{bA}$ \\
\hline
\end{tabular}

* Médias seguidas por letras distintas, maiúsculas $\mathrm{P}<0,01$ e minúsculas $\mathrm{P}<0,05$, diferem entre si pelo teste de Tuckey. 
O genótipo IAC-47 não apresentou diferença significativa com o IAC-1205 nas doses 0,$125 ; 1,25 ; 25,0$ e 50,0 $\mathrm{mg} \mathrm{L}^{-1}$, não assim na dose $0,625 \mathrm{mg}$ $\mathrm{L}^{-1}$, na qual o valor de potássio na matéria seca da parte aérea no IAC-1205 foi superior significativamente $(P<0,01)$ ao IAC-47.

Os resultados da análise estatística mostraram interações significativas $(P<0,01)$ entre genótipos e concentrações de ferro nas soluções, em relação à concentração de potássio na matéria seca da parte aérea.

Na Figura 11 é possivel observar o comportamento da concentração de potássio na matéria seca da parte aérea no genótipo IAC-47, em função dos níveis de ferro aplicados, na qual está representada a equação de regressão entre as concentrações de potássio na parte aérea e as doses de ferro. Assim a concentração de potássio para o IAC-47 ajustou-se a uma equação de segundo grau $(\mathrm{P}<0,01)$, com máximo valor na dose $12,5 \mathrm{mg} \mathrm{L}^{-1}$, e diminuindo a maiores doses. Para o genótipo IAC-1205 não se encontrou relação entre a concentração de potássio na matéria seca da parte aérea e níveis de ferro na solução.

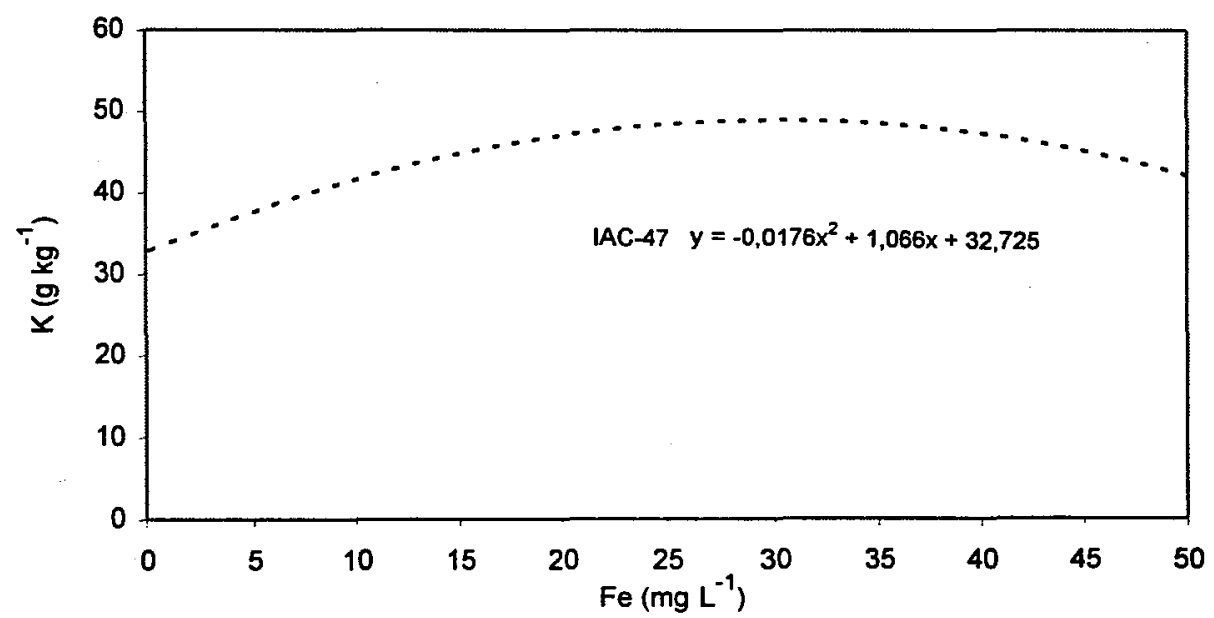

Figura 11. Relação entre concentração de potássio na matéria seca da parte aérea de dois genótipos de arroz e doses de Fe na solução. 
$\mathrm{Na}$ Tabela 16 são apresentados os valores de concentração de potássio na matéria seca das raízes $\left(\mathrm{g} \mathrm{kg}^{-1}\right)$ em função dos níveis de ferro estudados ( $m g \mathrm{~L}^{-1}$ ), dentro de cada genótipo. É possível observar segundo os resultados obtidos que os dois genótipos apresentaram comportamento semelhante, mostrando reduções na concentração de potássio nas raízes conforme aumentou-se a concentração de ferro na solução. Assim a concentração de potássio no genótipo IAC-1205 foi significativamente $(\mathrm{P}<0,01)$ superior a do IAC-47 na menor dose $\left(0,125 \mathrm{mg} \mathrm{L}^{-1}\right)$, e a nível $\mathrm{P}<0,05$ de significância na dose $0,625 \mathrm{mg} \mathrm{L}^{-1}$, diminuindo posteriormente nos dois genótipos conforme a adição de ferro na solução.

Tabela 16. Concentração de potássio $\left(\mathrm{g} \mathrm{kg}^{-1}\right)$ na matéria seca das raízes, de dois genótipos de arroz, em função das doses de ferro na solução nutritiva.

\begin{tabular}{lccccccc}
\hline & \multicolumn{5}{c}{$\mathrm{Fe}\left(\mathrm{mg} \mathrm{L}^{-1}\right)$} \\
Genótipos & 0,125 & 0,625 & 1,25 & 12,50 & 25,00 & 50,00 & Média \\
\hline IAC-47 & $7,18 \mathrm{bB}$ & $7,60 \mathrm{bA}$ & $7,88 \mathrm{aA}$ & $9,08 \mathrm{aA}$ & $5,95 \mathrm{aA}$ & $5,38 \mathrm{aA}$ & $7,18 \mathrm{bB}$ \\
IAC-1205 & $12,3 \mathrm{aA}$ & $9,75 \mathrm{aA}$ & $9,18 \mathrm{aA}$ & $8,85 \mathrm{aA}$ & $6,90 \mathrm{aA}$ & $5,35 \mathrm{aA}$ & $8,71 \mathrm{aA}$
\end{tabular}

* Médias seguidas por letras distintas, maiúsculas $\mathrm{P}<0,01$ e minúsculas $\mathrm{P}<0,05$, diferem entre si pelo teste de Tuckey.

Os resultados da análise estatística mostraram interações significativas $(P<0,01)$ entre genótipos e concentrações de ferro nas soluções, em relação à concentração de potássio na matéria seca das raízes. Encontrou-se também diferença significativa $(\mathrm{P}<0,01)$ entre genótipos e entre dose de ferro na solução.

Verificou-se uma tendência de diminuição nas concentrações de potássio nas raízes dos genótipos, conforme o incremento das concentrações de ferro na solução. Como mostra a Figura 12 os dois genótipos apresentam reduções 
na concentração de potássio nas raízes, ajustando-se os mesmos à equação de regressão linear negativa $(\mathrm{P}<0,01)$.

A adição de ferro em geral, provocou redução nos teores de potássio na parte aérea e raizes das plantas de arroz. Resultados semelhantes foram obtidos por (Fageria et.al., 1981; Melo Bastos, 1993), que encontraram redução da absorção de potássio em plantas de arroz, com o aumento da concentração de ferro na solução nutritiva, explicado pelo bloqueio da absorção nas raízes, originado pela camada de óxido férrico nas mesmas, acumulada por excesso desse nutriente na solução.

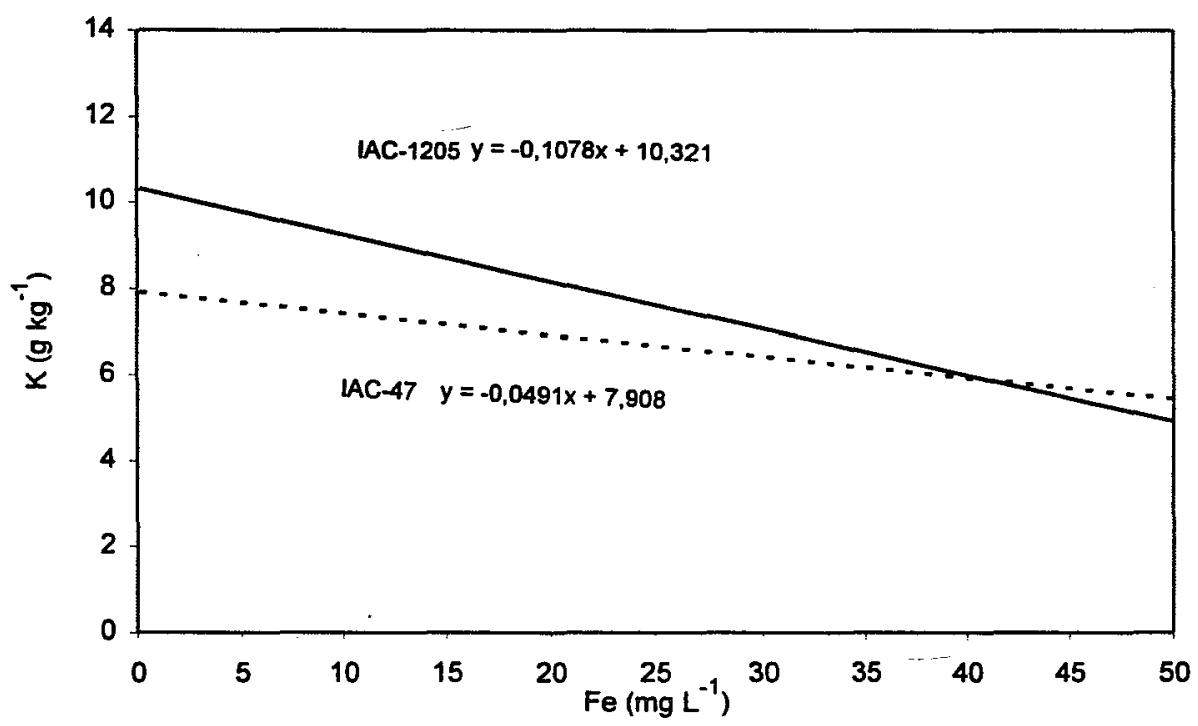

Figura 12Relação entre concentração de potássio na matéria seca das raizes de dois genótipos de arroz e doses de Fe na solução.

4.4.4. Cálcio na parte aérea e raízes.

A Tabela 17 apresenta a concentração de cálcio na matéria seca da parte aérea $\left(\mathrm{g} \mathrm{kg}^{-1}\right)$ em função dos níveis de ferro estudados $\left(\mathrm{mg} \mathrm{L}^{-1}\right)$, dentro de 
cada genótipo. Observa-se que os genótipos, embora tenham apresentado redução da concentração de cálcio na parte aérea com o aumento de ferro na solução, apresentaram diferentes valores de cálcio em relação aos níveis de ferro. Assim, o IAC-47 apresentou valores significativamente superiores ao IAC-1205 $(\mathrm{P}<0,05)$ nas menores doses $\left(0,125\right.$ e $\left.0,625 \mathrm{mg} \mathrm{L}^{-1}\right)$; já nas maiores doses de ferro os valores são menores que no IAC-1205, não havendo apresentado diferença significativa nas doses 1,$25 ; 25,0$ e $50,0 \mathrm{mg} \mathrm{L}^{-1}$, e sendo superado em valores de cálcio na parte aérea pelo IAC-1205 na dose $12,5 \mathrm{mg} \mathrm{L}^{-1}(\mathrm{P}<0,01)$.

Tabela 17. Concentração de cálcio $\left(\mathrm{g} \mathrm{kg}^{-1}\right)$ na matéria seca da parte aérea, de dois genótipos de arroz, em função das doses de ferro na solução nutritiva.

\begin{tabular}{lccccccc}
\hline & \multicolumn{5}{c}{$\mathrm{Fe}\left(\mathrm{mg} \mathrm{L}^{-1}\right)$} \\
Genótipos & 0,125 & 0,625 & 1,25 & 12,50 & 25,00 & 50,00 & Média \\
\hline IAC-47 & $11,15 \mathrm{aA}$ & $10,63 \mathrm{aA}$ & $9,08 \mathrm{aA}$ & $4,50 \mathrm{bB}$ & $5,28 \mathrm{aA}$ & $3,30 \mathrm{aA}$ & $7,32 \mathrm{aA}$ \\
IAC-1205 & $8,63 \mathrm{bA}$ & $\mathbf{8 , 3 0 \mathrm { bA }}$ & $9,28 \mathrm{aA}$ & $7,80 \mathrm{aA}$ & $6,35 \mathrm{aA}$ & $4,75 \mathrm{aA}$ & $7,52 \mathrm{aA}$ \\
\hline
\end{tabular}

* Médias seguidas por letras distintas, maiúsculas $P<0,01$ e minúsculas $P<0,05$, diferem entre si pelo teste de Tuckey.

Conforme os resultados estatísticos, foi encontrada interação significativa $(P<0,01)$ entre genótipos e concentração de ferro nas soluções, em relação a concentração de cálcio da parte aérea; verificando-se também efeitos significativos $(\mathrm{P}<0,01)$ de doses de ferro considerando a concentração de cálcio na matéria seca da parte aérea, não houve efeitos significativos entre os genótipos.

O comportamento da concentração de cálcio na matéria seca da parte aérea em cada genótipo, em função dos níveis de ferro aplicados, é apresentado na Figura 13, onde são representadas as equações de regressão entre concentração de cálcio na matéria seca da parte aérea e as doses de ferro para os dois genótipos estudados. Assim, todas as regressões representam a redução da concentração de 
cálcio na parte aérea em função dos níveis de ferro, porem o genótipo IAC-1205 apresentou reduções na concentração de cálcio na matéria seca da parte aérea representada pela equação linear negativa $(P<0,01)$, para o IAC-47 encontrou-se uma relação quadrática $(\mathrm{P}<0,01)$.

A redução da concentração de cálcio na parte aérea, confirma resultados obtidos por (Fageria, 1981; Barbosa Filho et.al., 1983), que segundo Howeler (1973), também ocorre em relação a outros nutrientes como $\mathrm{P}, \mathrm{K}$ e $\mathrm{Mg}$, provocando-se um bloqueio da absorção desses nutrientes através da camada de óxido férrico formada no sistema radicular.

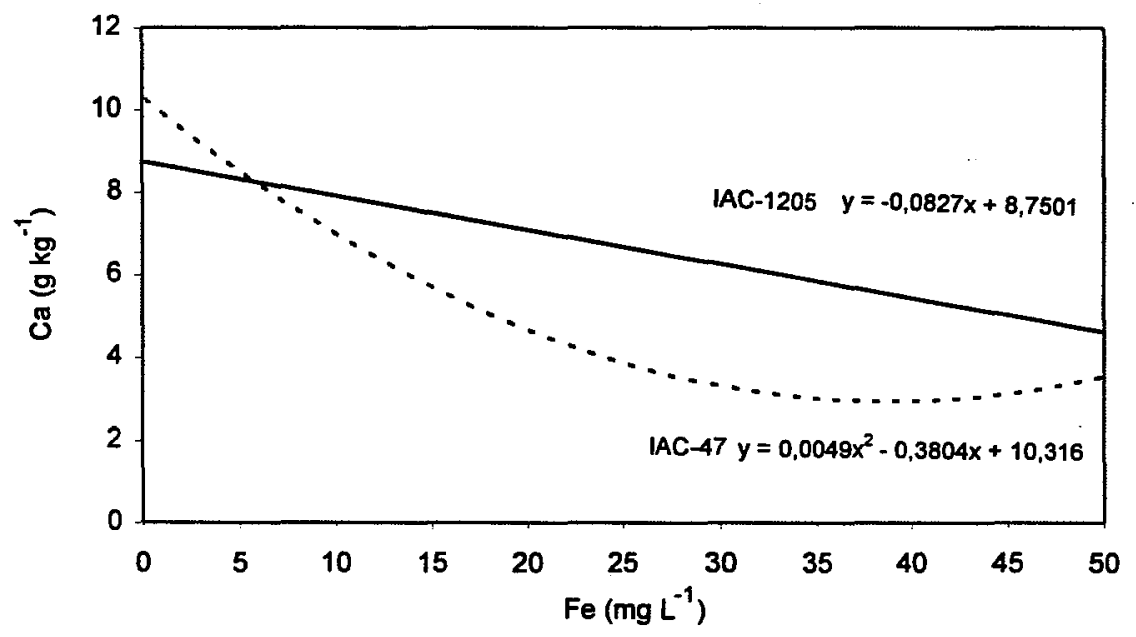

Figura 13. Relação entre concentração de cálcio na matéria seca da parte aérea de dois genótipos de arroz e doses de Fe na solução.

Na Tabela 18 são apresentadas as concentrações de cálcio na matéria seca das raízes $\left(\mathrm{g} \mathrm{kg}^{-1}\right)$ em função dos níveis de ferro estudados $\left(\mathrm{mg} \mathrm{L}^{-1}\right)$, dentro de cada genótipo. Segundo os resultados obtidos, o IAC-47 teve um leve aumento até a dose $1,25\left(\mathrm{mg} \mathrm{L}^{-1}\right)$, diminuindo logo conforme níveis crescentes de ferro na solução nutritiva. Enquanto que no IAC-1205 a concentração de cálcio aumentou 
com adições de ferro na solução nutritiva, apresentando assim valores inferiores que o IAC-47 nas menores doses, sem diferenças significativas até as maiores doses $\left(25,0\right.$ e 50,0 $\left.\mathrm{mg} \mathrm{L}^{-1}\right)$ em que a concentração de cálcio nas raízes no IAC-1205 foi superior estatísticamente $(\mathrm{P}<0,01)$.

Os resultados da análise estatística, mostraram que houve interação significativa $(P<0,05)$ entre genótipos e concentração de ferro na solução, em relação à concentração de cálcio na parte aérea. Verificou-se também efeitos significativos $(P<0,05)$ de genótipos e da concentração de ferro na solução nutritiva $(\mathrm{P}<0,01)$.

Tabela 18. Concentração de cálcio $\left(\mathrm{g} \mathrm{kg}^{-1}\right)$ na matéria seca das raízes, de dois genótipos de arroz, em função das doses de ferro na solução nutritiva.

\begin{tabular}{lccccccc}
\hline Genótipos & 0,125 & 0,625 & 1,25 & 12,50 & 25,00 & 50,00 & Média \\
\hline IAC-47 & $4,33 \mathrm{aA}$ & $5,20 \mathrm{aA}$ & $5,88 \mathrm{aA}$ & $5,03 \mathrm{aA}$ & $4,13 \mathrm{bB}$ & $3,93 \mathrm{bB}$ & $4,75 \mathrm{bA}$ \\
IAC-1205 & $4,33 \mathrm{aA}$ & $4,63 \mathrm{aA}$ & $5,63 \mathrm{aA}$ & $5,58 \mathrm{aA}$ & $5,58 \mathrm{aA}$ & $5,48 \mathrm{aA}$ & $5,20 \mathrm{aA}$ \\
\hline
\end{tabular}

* Médias seguidas por letras distintas, maiúsculas $P<0,01$ e minúsculas $P<0,05$, diferem entre si pelo teste de Tuckey.

O comportamento da concentração de cálcio na matéria seca das raízes no genótipo IAC-47, em função dos níveis de ferro aplicados, é apresentado na Figura 14 onde está representada a regressão entre concentração de cálcio e dose de ferro, para os dois genótipos em estudo, mostrando assim redução da concentração de cálcio na matéria seca das raízes do IAC-47, e ajustando-se a uma equação de regressão linear negativa $(P<0,01)$. Entretanto que para o genótipo IAC-1205 não foi encontrada relação entre concentração de cálcio na matéria seca das raizes e os níveis de ferro estudados. 


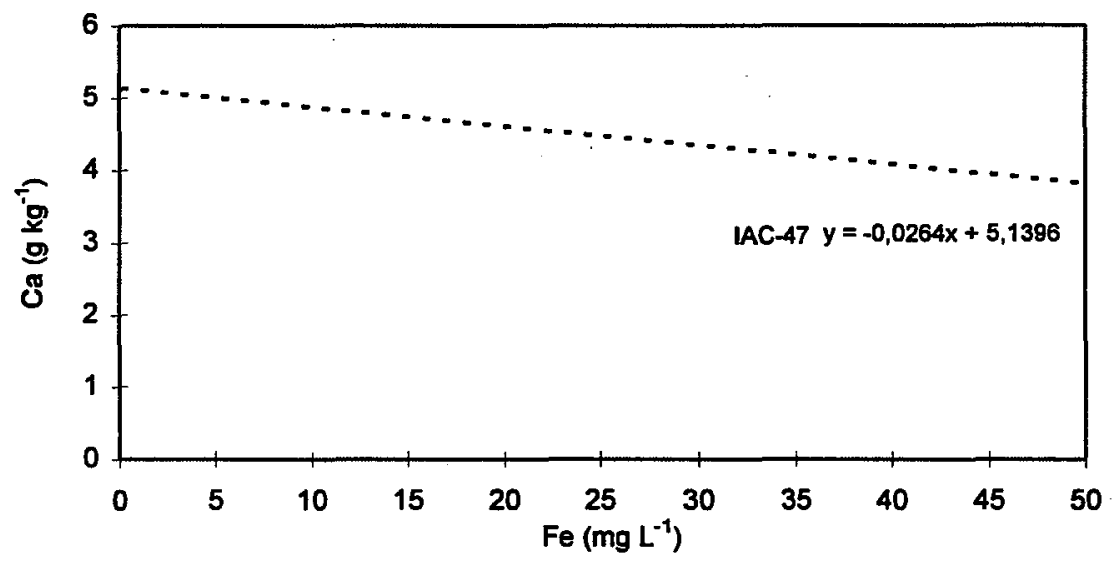

Figura 14. Relação entre concentração de cálcio na matéria seca das raizes de dois genótipos de arroz e doses de $\mathrm{Fe}$ na solução.

\subsubsection{Magnésio na parte aérea e raízes.}

A Tabela 19 apresenta a concentração de magnésio na matéria seca da parte aérea $\left(\mathrm{g} \mathrm{kg}^{-1}\right)$ em função dos níveis de ferro estudados $\left(\mathrm{mg} \mathrm{L}^{-1}\right)$, dentro de cada genótipo. Observa-se pelos resultados obtidos que os valores da concentração de magnésio no IAC-1205 foram significativamente maiores $(\mathrm{P}<0,05)$ que do IAC-47.

Os resultados da análise estatística mostraram, que não houve interação significativa entre genótipos e concentração de ferro nas soluções, em relação a concentração de magnésio na matéria seca da parte aérea. Não foram verificados efeitos significativos dos níveis de ferro sobre a concentração de magnésio na matéria seca da parte aérea, embora o genótipo IAC-1205 apresentou em todos os níveis de ferro, valores médios maiores que o IAC-47. Considerando a análise estatística através do teste de Tuckey, é possível observar que houve diferença entre as médias dos genótipos, verificando que a concentração de magnésio na parte aérea do IAC-1205 foi significativamente maior $(\mathrm{P}<0,05)$ que no IAC-47. 
Tabela 19. Concentração de magnésio $\left(\mathrm{g} \mathrm{kg}^{-1}\right)$ na matéria seca da parte aérea, de dois genótipos de arroz, em função das doses de ferro na solução nutritiva.

\begin{tabular}{lccccccc}
\hline Genótipos & 0,125 & 0,625 & 1,25 & 12,50 & 25,00 & 50,00 & Média \\
\hline IAC-47 & 5,20 & 4,75 & 5,00 & 4,80 & 4,80 & 4,58 & $4,86 \mathrm{bA}$ \\
IAC-1205 & 5,50 & 5,50 & 4,93 & 5,05 & 5,53 & 4,83 & $5,22 \mathrm{aA}$ \\
\hline
\end{tabular}

${ }^{*}$ Médias seguidas por letras distintas, maiúsculas $\mathrm{P}<0,01$ e minúsculas $\mathrm{P}<0,05$, diferem entre si pelo teste de Tuckey.

É apresentada na Tabela 20 a concentração de magnésio na matéria seca das raízes ( $\left.\mathrm{g} \mathrm{kg}^{-1}\right)$ em função dos níveis de ferro estudados $\left(\mathrm{mg} \mathrm{L}^{-1}\right)$, dentro de cada genótipo. Os dois genótipos apresentaram redução na concentração de magnésio nas raízes em função do aumento na concentração de ferro na solução.

Pelo teste de Tuckey o genótipo IAC-1205 apresentou concentrações de magnésio nas raizes significativamente superiores ao IAC-47 $(\mathrm{P}<0,01)$ nas menores doses $\left(0,125\right.$ e $\left.0,625 \mathrm{mg} \mathrm{L}^{-1}\right)$, e na dose $1,25 \mathrm{mg} \mathrm{L}^{-1}(\mathrm{P}<0,05)$, enquanto que não encontrou-se diferença nas maiores doses.

Tabela 20. Concentração de magnésio $\left(\mathrm{g} \mathrm{kg}^{-1}\right)$ na matéria seca das raízes, de dois genótipos de arroz, em função das doses de Fe na solução nutritiva.

\begin{tabular}{lccccccc}
\hline & \multicolumn{5}{c}{$F e\left(\mathrm{mg} \mathrm{L}^{-1}\right)$} \\
Genótipos & 0,125 & 0,625 & 1,25 & 12,50 & 25,00 & 50,00 & Média \\
\hline IAC-47 & $1,00 \mathrm{bB}$ & $1,00 \mathrm{bB}$ & $0,95 \mathrm{bA}$ & $1,28 \mathrm{aA}$ & $0,88 \mathrm{aA}$ & $0,73 \mathrm{aA}$ & $0,97 \mathrm{bA}$ \\
IAC-1205 & $1,38 \mathrm{aA}$ & $1,50 \mathrm{aA}$ & $1,25 \mathrm{aA}$ & $0,98 \mathrm{bA}$ & $0,85 \mathrm{aA}$ & $0,75 \mathrm{aA}$ & $1,12 \mathrm{aA}$ \\
\hline
\end{tabular}

${ }^{*}$ Médias seguidas por letras distintas, maiúsculas $\mathrm{P}<0,01$ e minúsculas $\mathrm{P}<0,05$, diferem entre si pelo teste de Tuckey.

Segundo os resultados da análise estatística, foi verificada interação significativa $(P<0,01)$ entre genótipos e concentração de ferro nas soluções, em relação a concentração de magnésio nas raízes, ao mesmo tempo que efeitos 
significativos $(\mathrm{P}<0,05)$ de genótipos, e dos níveis de ferro na solução nutritiva $(\mathrm{P}<0,01)$.

O comportamento da concentração de magnésio nas raízes em cada genótipo, em função dos níveis de ferro aplicados é apresentado na Figura 15, na qual estão representadas as equações de regressão entre a concentração de magnésio nas raízes e dose de ferro, para os dois genótipos estudados. Assim as regressões representam a redução da concentração de magnésio na matéria seca das raízes em função dos níveis de ferro na solução, apresentando os dois genótipos reduções ajustadas por equações lineares negativas, $\mathrm{P}<0,05$ para o IAC-47 e $\mathrm{P}<0,01$ para o IAC-1205. Concordando com resultados de Salardini \& Murphy (1975), que encontraram diminuição nas concentraçoes de magnésio, conforme aplicações de ferro na solução, e que segundo Moore et.al. (1990), altas concentrações de ferro no meio nutritivo podem provocar competição entre ferro e magnésio por sítios de absorção, suficente para diminuir o teor deste nutriente nas folhas das plantas de arroz. 


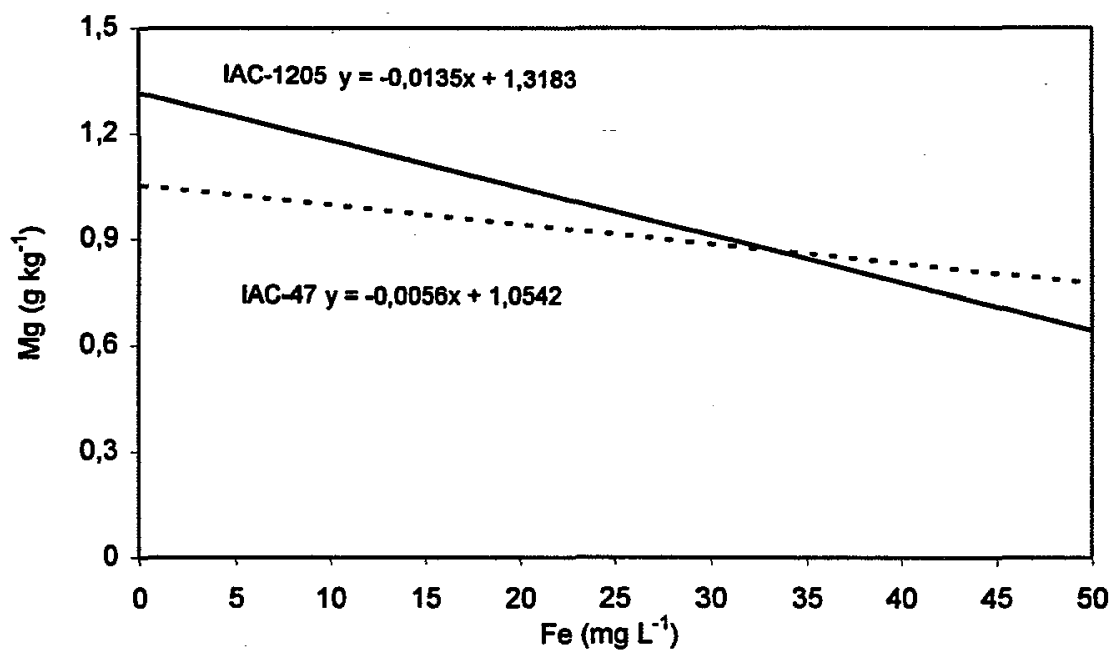

Figura 15. Relação entre concentração de magnésio na matéria seca das raízes de plantas de arroz e doses de Fe na solução.

4.5. Efeito de níveis de ferro na solução nutritiva sobre a concentração de alguns micronutrientes, nos genótipos de arroz estudados.

\subsubsection{Ferro na parte aérea e raízes.}

A concentração de ferro na matéria seca da parte aérea $\left(\mathrm{mg} \mathrm{kg}^{-1}\right) \mathrm{em}$ função dos níveis de ferro estudados $\left(\mathrm{mg} \mathrm{L}^{-1}\right)$, dentro de cada genótipo é apresentado na Tabela 21. Observa-se que os genótipos não apresentaram diferenças significativas conforme o aumento da concentração de ferro na solução, embora tenha se verificado pelos resultados obtidos, que a concentração de ferro no genótipo IAC-47 aumentou em função do incremento de ferro nas soluções, ao igual que o IAC-1205, que apresentou valores pouco mais elevados que o IAC-47 nas doses mais baixas até a dose $1,25 \mathrm{mg} \mathrm{L}^{-1}$, e valores bastante menores nas doses mais elevadas $\left(12,5 ; 25,0\right.$ e $\left.50,0 \mathrm{mg} \mathrm{L}^{-1}\right)$. Através do Teste de Tuckey encontrou-se 
diferença significativa $(P<0,05)$ entre as duas médias dos genótipos, verificando assim que o IAC-47 apresentou maior concentração de ferro que o IAC-1205, em função do aumento do ferro na solução.

Tabela 21. Concentração de ferro $\left(\mathrm{mg} \mathrm{kg}^{-1}\right)$ na matéria seca da parte aérea, de dois genótipos de arroz, em função das doses de ferro na solução nutritiva.

\begin{tabular}{lccccccc}
\hline & \multicolumn{5}{c}{$\mathrm{Fe}\left(\mathrm{mg} \mathrm{L}^{-1}\right)$} \\
Genótipos & 0,125 & 0,625 & 1,25 & 12,50 & 25,00 & 50,00 & Média \\
\hline IAC-47 & 215,3 & 218,3 & 265,8 & 586,5 & 907,5 & 885,8 & 513,2 aA \\
IAC-1205 & 225,8 & 220,3 & 279,8 & 552,3 & 654,8 & 681,0 & 435,6 bA \\
\hline
\end{tabular}

${ }^{*}$ Médias seguidas por letras distintas, maiúsculas $\mathrm{P}<0,01$ e minúsculas $\mathrm{P}<0,05$, diferem entre si pelo teste de Tuckey.

Verificou-se que o teor de ferro aumentou na parte aérea nos dois genótipos conforme incrementou-se o teor desse elemento nas soluções nutritivas, concordando com trabalhos de De Kock et al. (1960); Yunusa (1980) e Fageria (1981).

O genótipo IAC-1205, que mostrou-se mais tolerante ao excesso de ferro, foi o que apresentou menor concentração desse elemento na planta, provavelmente seja devido a uma menor absorção deste pela planta, confirmando resultados obtidos por Camargo (1984), trabalhando com outros genótipos. Enquanto que o genótipo IAC-47 foi mais sensível ao excesso de ferro, apresentando valores elevados do mesmo na planta, pelo qual poderia ser sugerido que IAC-47 seria mais eficiente em absorver ferro a concentrações mais elevadas de ferro na solução nutritiva. Segundo Fageria et al. (1990), os fatores de resposta a estresse de ferro estão associados com o aumento pelas plantas da absorção desse elemento. Estes resultados coincidem com aqueles encontrados por Fageria et.al. 
(1984), os quais demonstram que os genótipos de arroz diferem em tolerância a toxidez de ferro, concordando também com Shimada (1995). Segundo este autor existe uma diferença varietal na tolerância ao excesso de ferro, assim como a habilidade que tem a planta de arroz de absorver este nutriente. A toxidez poderia estar asociada a um aumento na absorção e na translocação de ferro para a parte aérea (Brown \& Jones, 1977; Tadano, 1975).

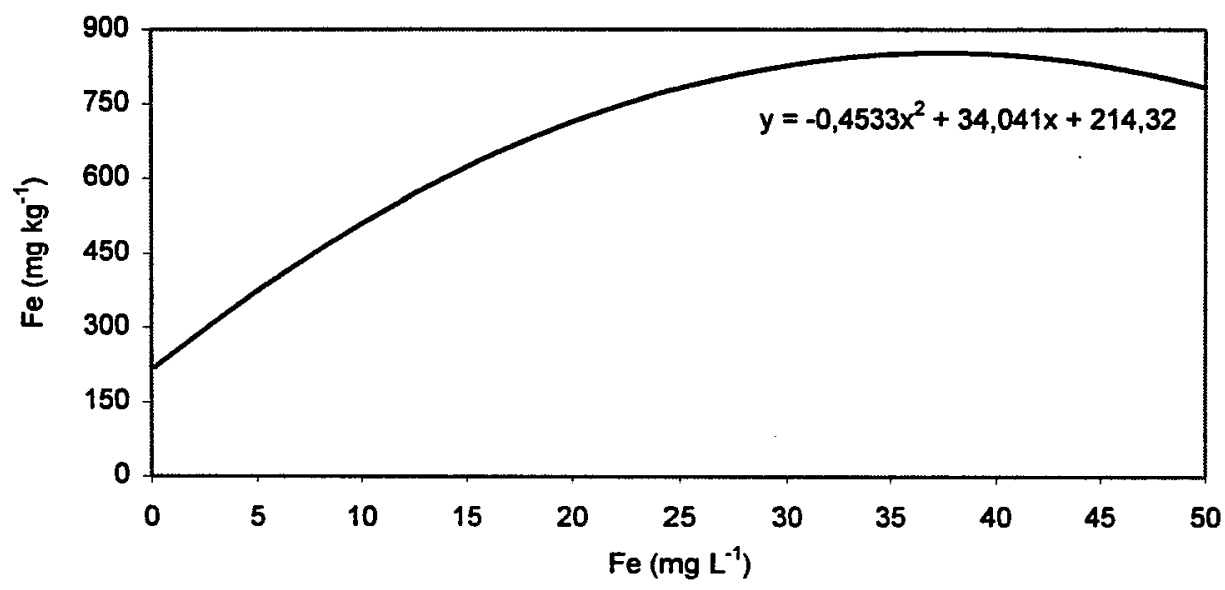

Figura 16. Relação entre a concentração de ferro na matéria seca da parte aérea de dois genótipos de arroz, e niveis de Fe na solução.

- Não se encontrou significância na interação entre ferro na parte aérea e níveis de ferro aplicados na solução para cada genótipo em estudo, mas sim entre dose de ferro na solução $(\mathrm{P}<0,01)$, e também entre as médias dos genótipos. A regressão polinomial para os níveis de ferro foi significativa $(\mathrm{P}<0,01)$ para a equação de segundo grau. O comportamento da concentração de ferro na matéria seca da parte aérea de cada genótipo em função dos níveis de ferro aplicados, é apresentado na Figura 16, embora não se tenha verificado diferença estatística significativa para os dois genótipos em função do incremento dos níveis de ferro na 
solução, houve uma tendência de aumento do elemento ferro na parte aérea dos genótipos em estudo, conforme o aumento da concentração de ferro na solução.

É apresentada na Tabela 22 a concentração de ferro na matéria seca das raízes $\left(\mathrm{mg} \mathrm{kg}^{-1}\right)$ em função dos níveis de ferro estudados $\left(\mathrm{mg} \mathrm{L}^{-1}\right)$, dentro de cada genótipo. Foram encontrados comportamentos semelhantes dos genótipos em relação aos níveis de ferro. Assim, a concentração de ferro nas raízes nos dois genótipos, incrementou conforme a adição de ferro nas soluções. Embora não tenha sido verificada diferença significativa entre os dois genótipos nas menores doses $\left(0,125 ; 0,625\right.$ e $\left.1,25 \mathrm{mg} \mathrm{L}^{-1}\right)$, nas maiores doses de ferro na solução $(12,5$; 25,0 e 50,0 $\mathrm{mg} \mathrm{L}^{-1}$ ) o IAC-1205 apresentou valores de concentração de ferro nas raízes significativamente menores $(\mathrm{P}<0,01)$ que o IAC-47.

Tabela 22. Concentração de ferro $\left(\mathrm{mg} \mathrm{kg}^{-1}\right)$ na matéria seca das raizes, de dois genótipos de arroz, em função das doses de ferro na solução nutritiva.

\begin{tabular}{lccccccc}
\hline Genótipos & 0,125 & 0,625 & 1,25 & 12,50 & 25,00 & 50,00 & Média \\
\hline IAC-47 & $902 \mathrm{aA}$ & $1496 \mathrm{aA}$ & $2300 \mathrm{aA}$ & $41744 \mathrm{aA}$ & $70820 \mathrm{aA}$ & $79011 \mathrm{aA}$ & $32712 \mathrm{aA}$ \\
IAC-1205 & $2348 \mathrm{aA}$ & $1331 \mathrm{aA}$ & $2101 \mathrm{aA}$ & $24205 \mathrm{bB}$ & $40754 \mathrm{bB}$ & $59704 \mathrm{bB}$ & $21574 \mathrm{bB}$ \\
\hline
\end{tabular}

* Médias seguidas por letras distintas, maiúsculas $\mathrm{P}<0,01$ e minúsculas $\mathrm{P}<0,05$, diferem entre si pelo teste de Tuckey.

Os resultados da análise estatística mostraram interações significativas $(P<0,01)$ entre genótipos e concentração de ferro nas soluções, em relação a concentração de ferro nas raízes. Encontrou-se também efeitos significativos $(\mathrm{P}<0,01)$ de genótipos $\mathrm{e}$ dos níveis de ferro nas soluções, considerando a concentração de ferro na matéria seca das raízes.

A concentração de ferro nas raízes em cada genótipo, em função dos níveis de ferro aplicados, é apresentado na Figura 17, na qual são apresentadas as 
equações de regressão entre concentração de ferro na matéria seca das raízes e os níveis de ferro para os genótipos estudados, a relação para cada genótipo ajustou-se $(\mathrm{P}<0,01)$ a uma equação de regressão de segundo grau.

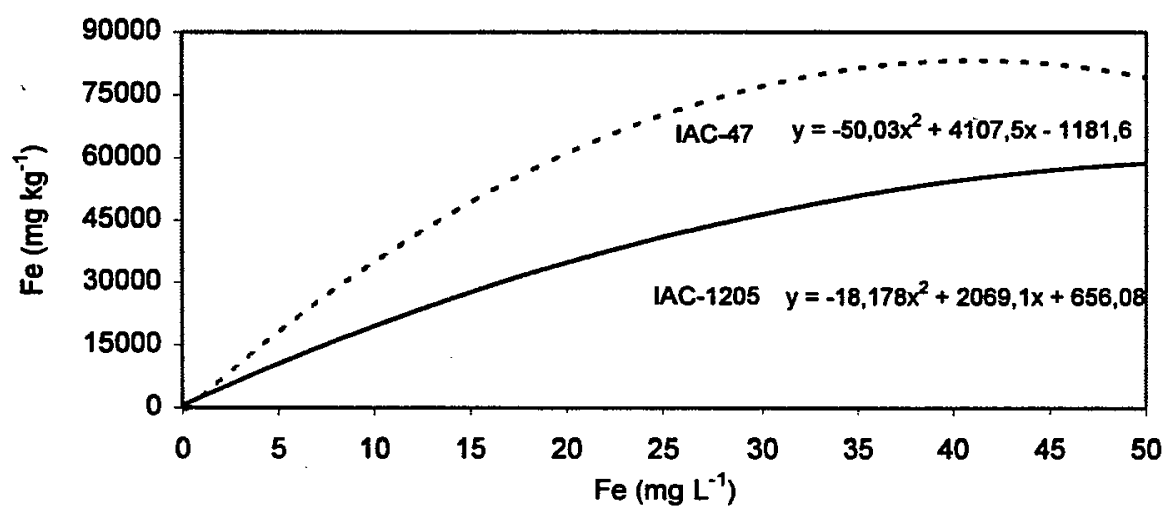

Figura 17. Relação entre a concentração de ferro na matéria seca das raizes de dois genótipos de arroz e niveis de Fe na solução.

Nos dois genótipos encontrou-se que a concentração de ferro nas raízes, foi superior ao encontrado na matéria seca da parte aérea, confirmando resultados obtidos por Yoshida \& Takahashi (1958); Bacha (1976) e Yunusa, (1980), e que segundo Tanaka (1966), pode ser encontrada grande quantidade de ferro depositado na superficie e na epiderme das raízes de arroz, a diferença de outros nutrientes que estão presentes em maiores concentrações no caule e nas folhas das plantas.

Coincidindo com as tendências das concentrações de ferro encontradas na parte aérea em função dos níveis de ferro na solução nutritiva para os dois genótipos em estudo, verificou-se que nas raízes, o genótipo IAC-47 acumulou maior quantidade de ferro que o IAC-1205, indicando estes resultados que o IAC-47 poderia ser prejudicado quando submetido a altos níveis de ferro na solução nutritiva, enquanto que o IAC-1205 teria maior tolerância a altas concentrações de ferro. 


\subsubsection{Manganês na parte aérea e raízes.}

A Tabela 23 apresenta a concentração de manganês na matéria seca da parte aérea ( $\left.\mathrm{mg} \mathrm{kg}^{-1}\right)$ em função dos níveis de ferro estudados $\left(\mathrm{mg} \mathrm{L}^{-1}\right)$, dentro de cada genótipo. Foi verificado que os genótipos tiveram comportamento semelhante, com poucas modificações nas menores doses $(0,125 ; 0,625$ e $1,25 \mathrm{mg}$ $\mathrm{L}^{-1}$ ), aumentando logo com o incremento do ferro na solução. O IAC-47 apresentou o máximo valor na dose 12,5 e o IAC-1205 no nível $25,0 \mathrm{mg} \mathrm{L}^{-1}$, diminuindo este na máxima concentração de ferro na solução $\left(50,0 \mathrm{mg} \mathrm{L}^{-1}\right)$.

Tabela 23. Concentração de manganês $\left(\mathrm{mg} \mathrm{kg}^{-1}\right)$ na matéria seca da parte aérea, de dois genótipos de arroz, em função das doses de ferro na solução nutritiva.

\begin{tabular}{lccccccc}
\hline Genótipos & 0,125 & 0,625 & 1,25 & 12,50 & 25,00 & 50,00 & Média \\
\hline IAC-47 & 169,0 & 152,75 & 172,0 & 244,0 & 195,5 & 224,5 & $193,0 \mathrm{bA}$ \\
IAC-1205 & 197,5 & 186,5 & 212,8 & 233,5 & 239,8 & 226,0 & $216,0 \mathrm{aA}$ \\
\hline
\end{tabular}

* Médias seguidas por letras distintas, maiúsculas $\mathrm{P}<0,01$ e minúsculas $\mathrm{P}<0,05$, diferem entre si pelo teste de Tuckey.

Pelos resultados da análise estatística, não foram verificadas interações significativas entre genótipos e concentração de ferro nas soluções nutritivas, em relação a concentração de manganês na parte aérea, embora se tenha encontrado efeitos significativos $(\mathrm{P}<0,01)$ de genótipos e dos níveis de ferro nas soluções, considerando a concentração de manganês na parte aérea. A regressão polinomial para os níveis de ferro é representada pela equação de segundo grau 
$(\mathrm{P}<0,01)$. O comportamento da concentração de manganês na parte aérea em cada genótipo, em função dos níveis de ferro aplicados, é apresentado na Figura 18.

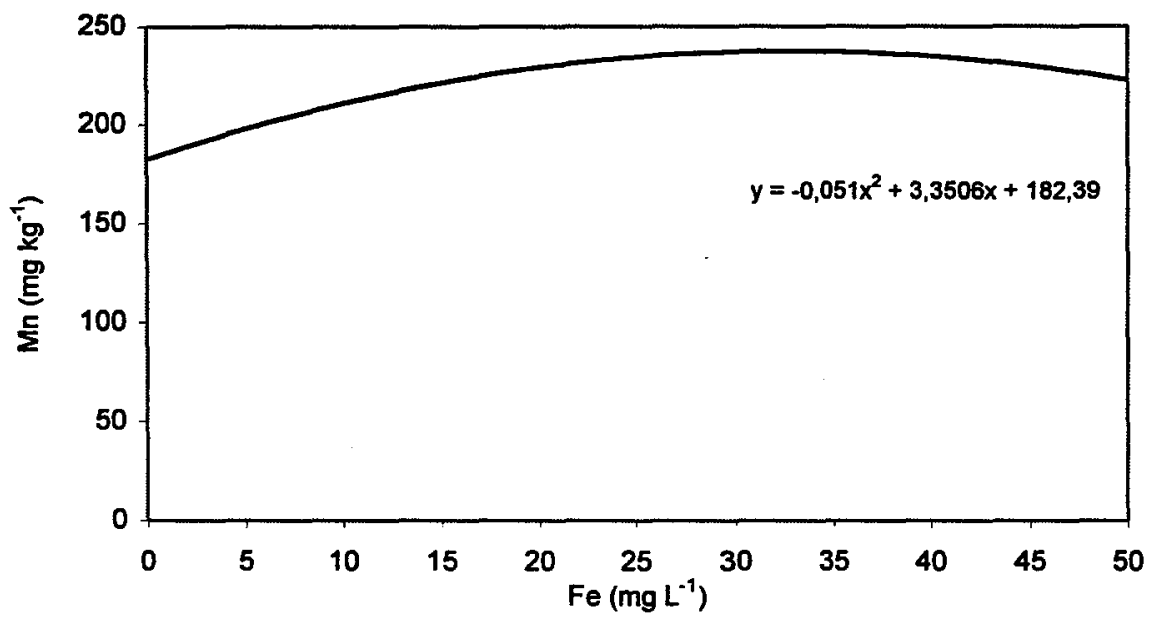

Figura 18. Relação entre a concentração de manganés na matéria seca da parte aérea de dois genótipos de arroz e niveis de Fe na solução.

Pelos dados obtidos, verificou-se uma tendência de aumento da concentração de manganês na planta, conforme aumentou-se a dose de ferro nas soluções, confirmando resultados encontrados por Camargo (1984), trabalhando com o nutriente ferro em solução nutritiva e cultivares de arroz. Uma relação inversa entre ferro e manganês foi encontrado por Tanaka \& Navasero (1966), trabalhando com plantas de arroz, encontrando que o manganês na parte aérea é diminuído por altas concentrações de ferro na solução, esta relação não foi observada neste experiência, e concordando com Bacha (1976), pode ser devido a que o ferro não atingiu valores suficientemente altos na solução para interferir na absorção de manganês, porém segundo Bacha (1976), o ferro pode ter sido 
absorvido pelas plantas, depositado sobre a epiderme das raízes, ou precipitado desde a solução.

A concentração de manganês na matéria seca das raízes $\left(\mathrm{mg} \mathrm{kg}^{-1}\right)$, em função dos níveis de ferro aplicados, é apresentado na Tabela 24. Observa-se que como na parte aérea, os dois genótipos apresentaram comportamento semelhante; embora não tenha sido verificada interação entre genótipos e concentração de ferro nas soluções em relação a concentração de manganês. No IAC-47 aumentou a concentração conforme incrementava-se o ferro nas soluções até o valor máximo no nível $1,25 \mathrm{mg} \mathrm{L}^{-1}$, diminuindo com adições de ferro. Enquanto que o IAC-1205 apresentou incremento na concentração de manganês do nível 0,125 para $0,625 \mathrm{mg} \mathrm{kg}^{-1}$, apresentando a maior concentração nesta dose, com posteriores diminuições conforme o aumento de ferro nas soluções.

Tabela 24. Concentração de manganês $\left(\mathrm{mg} \mathrm{kg}^{-1}\right)$ na matéria seca das raízes, de dois genótipos de arroz, em função das doses de ferro na solução nutritiva.

\begin{tabular}{lccccccc}
\hline Genótipos & 0,125 & 0,625 & 1,25 & 12,50 & 25,00 & 50,00 & Média \\
\hline IAC-47 & 23,25 & 25,50 & 26,50 & 21,00 & 15,75 & 14,75 & $21,13 \mathrm{aA}$ \\
IAC-1205 & 19,50 & 28,75 & 20,25 & 16,50 & 13,75 & 11,75 & $18,42 \mathrm{aA}$ \\
\hline
\end{tabular}

* Médias seguidas por letras distintas, maiúsculas $\mathrm{P}<0,01$ e minúsculas $\mathrm{P}<0,05$, diferem entre si pelo teste de Tuckey.

Pelos resultados da análise estatística não se verificou efeitos significativos de genótipos, constatando-se diferenças $(\mathrm{P}<0,01)$ para a concentração de manganês nas raízes em função das doses de ferro. A regressão polinomial para os níveis de ferro e concentração de manganês nas raízes dos genótipos estudados, é representada pela equação linear negativa $(\mathrm{P}<0,01)$, apresentada na Figura 19. A redução observada nos teores de manganês nas raízes conforme aumenta a concentração de ferro na solução, estão de acordo com 
resultados encontrados por Salardini \& Murphy (1975) e Yunusa (1980), também citado por Jones et.al. (1991). Conforme Zaharieva (1986), o ferro e manganês são absorvidos por um mecanismo comum, competindo por sítio ativos de transporte na membrana celular, sendo que plantas cloróticas apresentam alta relação $\mathrm{Mn} / \mathrm{Fe}^{2+}$.

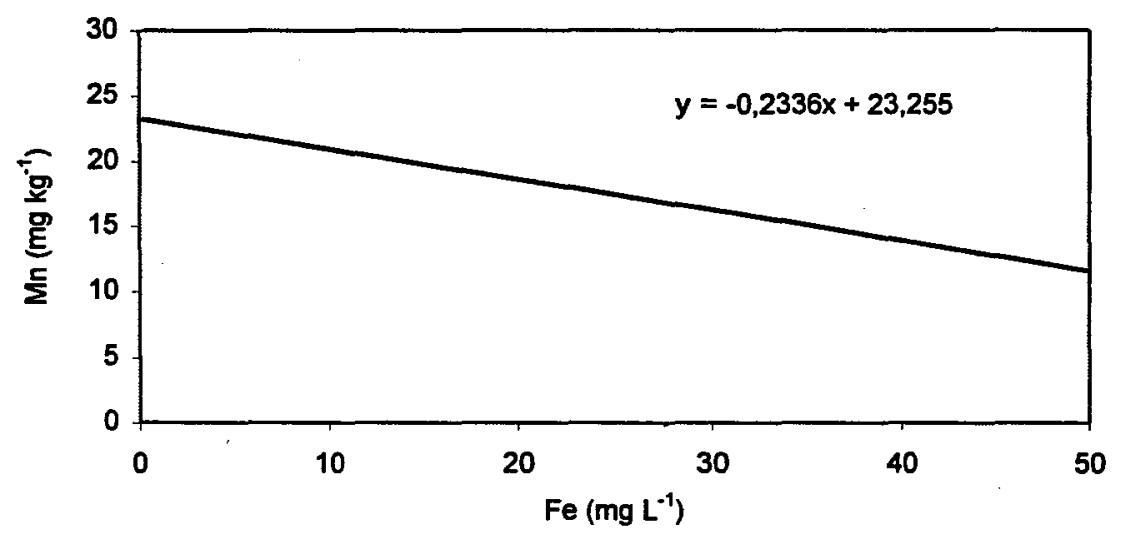

Figura 19. Relação entre a concentração de manganés na matéria seca das raízes de dois genótipos de arroz, e niveis de Fe na solução.

Confirmando as informações de Bacha (1976), verificou-se também, que a concentração de manganês na parte aérea foi superior às raízes, explicado segundo este autor, pela função do manganês na planta que está relacionada à assimilação do carbono, produzida na parte aérea. Alguns autores citam 3 a 8 vezes maior a concentração de manganês nas folhas que nas raízes, concordando com resultados obtidos neste experimento.

\subsubsection{Cobre na parte aérea e raízes.}

A Tabela 25 apresenta a concentração de cobre na matéria seca da parte aérea $\left(\mathrm{mg} \mathrm{kg}^{-1}\right)$ em função dos níveis de ferro estudados $\left(\mathrm{mg} \mathrm{L}^{-1}\right)$, dentro de cada genótipo. Observa-se que os níveis de ferro na solução nutritiva tiveram 
pouco efeito sobre a quantidade de cobre acumulado pela parte aérea das plantas, concordando com resultados encontrados por Yunusa (1980), estudando níveis de ferro em sorgo.

Tabela 25. Concentração de cobre $\left(\mathrm{mg} \mathrm{kg}^{-1}\right)$ na matéria seca da parte aérea, de dois genótipos de arroz, em função das doses de ferro na solução nutritiva.

\begin{tabular}{lccccccc}
\hline Genótipos & 0,125 & 0,625 & 1,25 & 12,50 & 25,00 & 50,00 & Média \\
\hline IAC-47 & $16,3 \mathrm{bB}$ & $11,0 \mathrm{aA}$ & $16,3 \mathrm{aA}$ & $21,8 \mathrm{aA}$ & $24,0 \mathrm{aA}$ & $27,0 \mathrm{aA}$ & $19,4 \mathrm{aA}$ \\
IAC-1205 & $28,3 \mathrm{aA}$ & $16,5 \mathrm{aA}$ & $18,3 \mathrm{aA}$ & $17,8 \mathrm{aA}$ & $20,0 \mathrm{aA}$ & $20,0 \mathrm{aA}$ & $20,1 \mathrm{aA}$ \\
\hline
\end{tabular}

${ }^{*}$ Médias seguidas por letras distintas, maiúsculas $\mathrm{P}<0,01$ e minúsculas $\mathrm{P}<0,05$, diferem entre si pelo teste de Tuckey.

Pelos resultados da análise estatística, foi verificada interação significativa $(P<0,05)$ entre a concentração de ferro nas soluções em relação à concentração de cobre, para os genótipos em estudo. Não se encontrou efeitos significativos de genótipos, mas sim de dose de $\mathrm{Fe}(\mathrm{P}<0,05)$. O IAC-47 apresentou valores baixos nas menores doses, enquanto que nas doses mais elevadas apresentou aumento nos valores de concentração, com máxima concentração na dose $50,0 \mathrm{mg} \mathrm{kg}^{-1}$. É possível observar na Figura 20, o comportamento no genótipo IAC-47 ajustando-se uma equação linear $(\mathrm{P}<0,01)$, entretanto para o IAC1205 não se verificou relação entre concentração de cobre na parte aérea e doses de ferro na solução. 


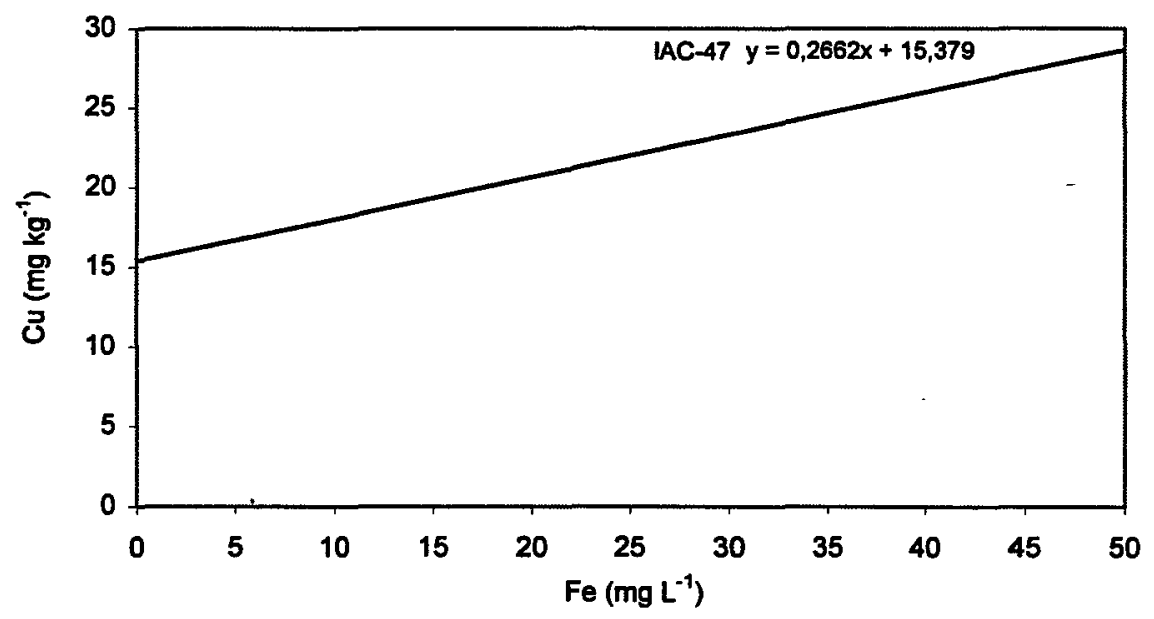

Figura 20. Relação entre concentraçāo de cobre na matéria seca da parte aérea de dois genótipos de arroz e doses de Fe na solução.

É apresentada na Tabela 26, a concentração de cobre na matéria seca das raízes (mg kg-1) em função dos níveis de ferro estudados $\left(\mathrm{mg} \mathrm{L}^{-1}\right)$, dentro de cada genótipo. Yunusa (1980), verificou que nas maiores doses de ferro na solução, as plantas evidenciaram uma tendência a acumular maiores quantidades de cobre nas raízes que na parte aérea.

O comportamento da concentração de cobre nas raízes dos genótipos em estudo, foi semelhante ao encontrado na parte aérea, onde o IAC-47 apresentou maior valor na dose mais elevada de ferro $\left(50,0 \mathrm{mg} \mathrm{L}^{-1}\right)$, enquanto que para o genótipo IAC-1205 a concentração de cobre mais elevada foi encontrada na menor dose $\left(0,125 \mathrm{mg} \mathrm{L}^{-1}\right)$.

Tabela 26. Concentração de cobre $\left(\mathrm{mg} \mathrm{kg}^{-1}\right)$ na matéria seca das raízes, de dois genótipos de arroz, em função das doses de ferro na solução nutritiva.

\begin{tabular}{lccccccc}
\hline Genótipos & 0,125 & 0,625 & 1,25 & 12,50 & 25,00 & 50,00 & Média \\
\hline IAC-47 & $17,8 \mathrm{bA}$ & $26,3 \mathrm{aA}$ & $31,0 \mathrm{aA}$ & $35,5 \mathrm{aA}$ & $15,0 \mathrm{bA}$ & $45,5 \mathrm{aA}$ & $28,5 \mathrm{aA}$ \\
IAC-1205 & $40,0 \mathrm{aA}$ & $36,3 \mathrm{aA}$ & $30,0 \mathrm{aA}$ & $21,5 \mathrm{aA}$ & $35,3 \mathrm{aA}$ & $12,0 \mathrm{bB}$ & $29,2 \mathrm{aA}$ \\
\hline
\end{tabular}

${ }^{*}$ Médias seguidas por letras distintas, maiúsculas $\mathrm{P}<0,01$ e minúsculas $\mathrm{P}<0,05$, diferem entre si pelo teste de Tuckey. 
Os resultados da análise estatística mostraram interações significativas $(P<0,01)$ entre genótipos e concentração de ferro, em relação a concentração de cobre na matéria seca das raizes, não se encontrando efeitos significativos de genótipos e concentração de ferro nas soluções. Na Figura 21 é apresentado o comportamento da concentração de cobre nas raízes em função das dose de ferro na solução para cada genótipo, observa-se que a relação para o IAC47 foi ajustada significativamente $(P<0,05)$ a uma equação de regressão linear positiva, com aumentos na concentração de cobre nas raízes em função das doses de ferro na solução, enquanto que para o IAC-1205 ajustou-se significativamente $(\mathrm{P}<0,01)$ a uma equação linear negativa, diminuindo a concentração de cobre nas raízes conforme o incremento dos níveis de ferro na solução nutritiva.

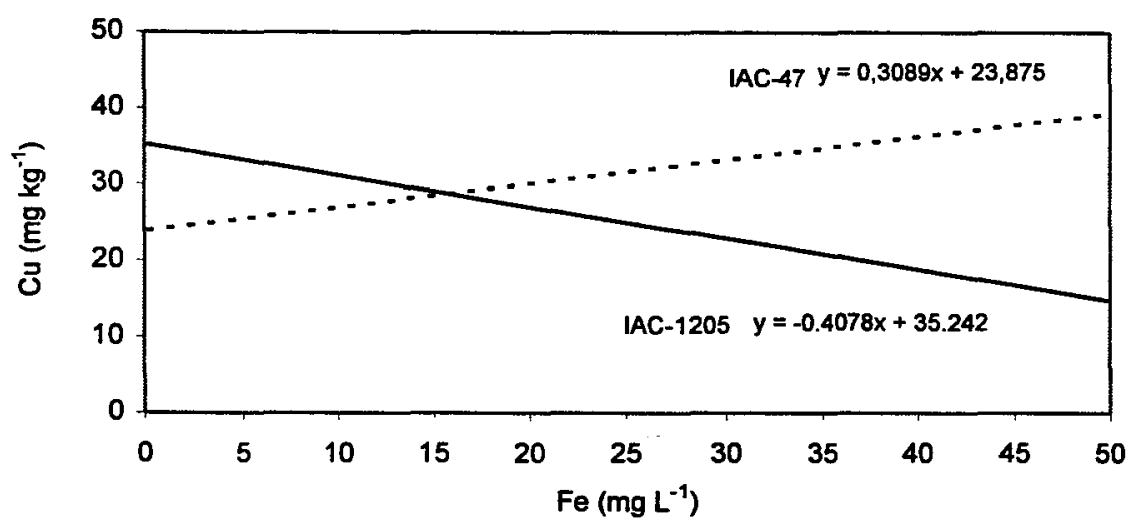

Figura 21. Relação entre a concentração de cobre na matéria seca das raizes de dois genótipos de arroz, e doses de Fe na solução.

\subsubsection{Zinco na parte aérea e raízes.}

A concentração de zinco na matéria seca da parte aérea $\left(\mathrm{mg} \mathrm{kg}^{-1}\right) \mathrm{em}$ função dos níveis de ferro estudados $\left(\mathrm{mg} \mathrm{L}^{-1}\right)$, dentro de cada genótipo é apresentado na Tabela 27. Observa-se que os genótipos estudados apresentaram 
comportamento diferente em relação aos níveis de ferro. Assim, no IAC-47 incrementou-se a concentração de zinco na parte aérea até a dose $12,5 \mathrm{mg} \mathrm{L}^{-1}$, diminuindo posteriormente em função do aumento da concentração de ferro nas soluções, valores estes maiores que no IAC-1205. Verificou-se que no IAC-1205 a concentração de zinco diminuiu com adições de ferro na solução até o nível 1,25 $\mathrm{mg} \mathrm{L} \mathrm{L}^{-1}$.

Através dos resultados da análise estatística foram verificadas interações significativas $(P<0,05)$ entre genótipos e concentração de ferro, em relação à concentração de zinco na matéria seca da parte aérea. Encontrou-se também diferença significativa $(P<0,01)$ entre genótipos, não se verificando efeito de doses de ferro nas soluções, para a concentração de zinco na matéria seca da parte aérea.

Tabela 27. Concentração de zinco $\left(\mathrm{mg} \mathrm{kg}^{-1}\right)$ na matéria seca da parte aérea, de dois genótipos de arroz, em função das doses de ferro na solução nutritiva.

\begin{tabular}{lccccccc}
\hline Genótipos & 0,125 & 0,625 & 1,25 & 12,50 & 25,00 & 50,00 & Média \\
\hline IAC-47 & $61,0 \mathrm{aA}$ & $57,3 \mathrm{aA}$ & $64,3 \mathrm{aA}$ & $87,3 \mathrm{aA}$ & $70,0 \mathrm{aA}$ & $67,3 \mathrm{aA}$ & $67,8 \mathrm{aA}$ \\
IAC-1205 & $64,8 \mathrm{aA}$ & $61,8 \mathrm{aA}$ & $51,5 \mathrm{aA}$ & $53,0 \mathrm{bB}$ & $59,3 \mathrm{aA}$ & $60,8 \mathrm{aA}$ & $58,5 \mathrm{bB}$ \\
\hline
\end{tabular}

${ }^{*}$ Médias seguidas por letras distintas, maiúsculas $\mathrm{P}<0,01$ e minúsculas $\mathrm{P}<0,05$, diferem entre si pelo teste de Tuckey.

É possivel observar na Figura 22, a relação entre concentração de zinco na matéria seca da parte aérea e níveis de ferro na solução nutritiva para o genótipo IAC-47, comportamento este representado pela equação de regressão de segundo grau, verificando-se aumento até a dose $12,50 \mathrm{mg} \mathrm{L}^{-1}$ e posterior diminuição com adições de ferro na solução. Entretanto para o IAC-1205 não foi 
encontrada relação entre concentração de zinco na parte aérea e dose de ferro na solução.

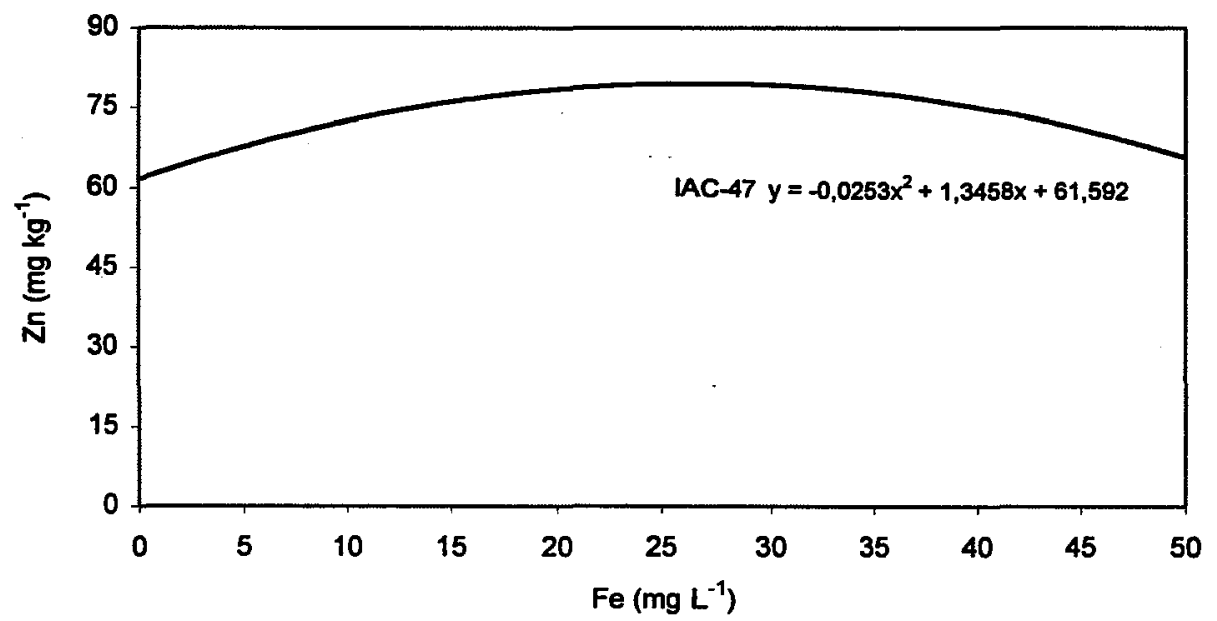

Figura 22. Relação entre concentração de zinco na matéria seca da parte aérea de dois genótipos de arroz e doses de Fe na solução.

A Tabela 28 apresenta a concentração de zinco na matéria seca das raízes $\left(\mathrm{mg} \mathrm{kg}^{-1}\right)$ em função dos níveis de ferro estudados $\left(\mathrm{mg} \mathrm{L}^{-1}\right)$, dentro de cada genótipo. É possível observar que os dois genótipos tiveram comportamento semelhante, incrementando-se o valor da concentração de zinco na matéria seca das raízes em função do aumento da concentração de ferro em solução, apresentando o IAC-47 menores concentrações de zinco na matéria seca das raízes.

Tabela 28. Concentração de zinco $\left(\mathrm{mg} \mathrm{kg}^{-1}\right)$ na matéria seca das raízes, de dois genótipos de arroz, em função das doses de ferro na solução nutritiva.

\begin{tabular}{lccccccc}
\hline \multirow{2}{*}{ Genótipos } & 0,125 & 0,625 & 1,25 & 12,50 & 25,00 & 50,00 & Média \\
\hline IAC-47 & 33,0 & 34,8 & 38,8 & 40,0 & 46,0 & 39,5 & $38,7 \mathrm{bA}$ \\
IAC-1205 & 38,5 & 34,3 & 38,5 & 54,8 & 55,0 & 55,8 & $46,1 \mathrm{aA}$ \\
\hline
\end{tabular}

* Médias seguidas por letras distintas, maiúsculas $\mathrm{P}<0,01$ e minúsculas $\mathrm{P}<0,05$, diferem entre si pelo teste de Tuckey. 
As concentrações foram geralmente superiores na parte aérea dos genótipos, comparados às encontradas nas raízes, resultado que concorda com o obtido por Yunusa (1980).

Pelos resultados da análise estatística, não foram verificadas interações significativas entre genótipos e concentrações de ferro nas soluções nutritivas, em relação a concentração de zinco nas raízes. Efeitos significativos $(P<0,05)$ foram encontrados entre genótipos e entre concentrações de ferro na solução em relação a concentração de zinco na matéria seca das raízes.

O comportamento da concentração de zinco nas raízes para os dois genótipos, em função dos níveis de ferro aplicados, é apresentado na Figura 23, verificando-se que a regressão polinomial para os níveis de ferro é representada pela equação de segundo grau, semelhante a relação encontrada para a parte aérea.

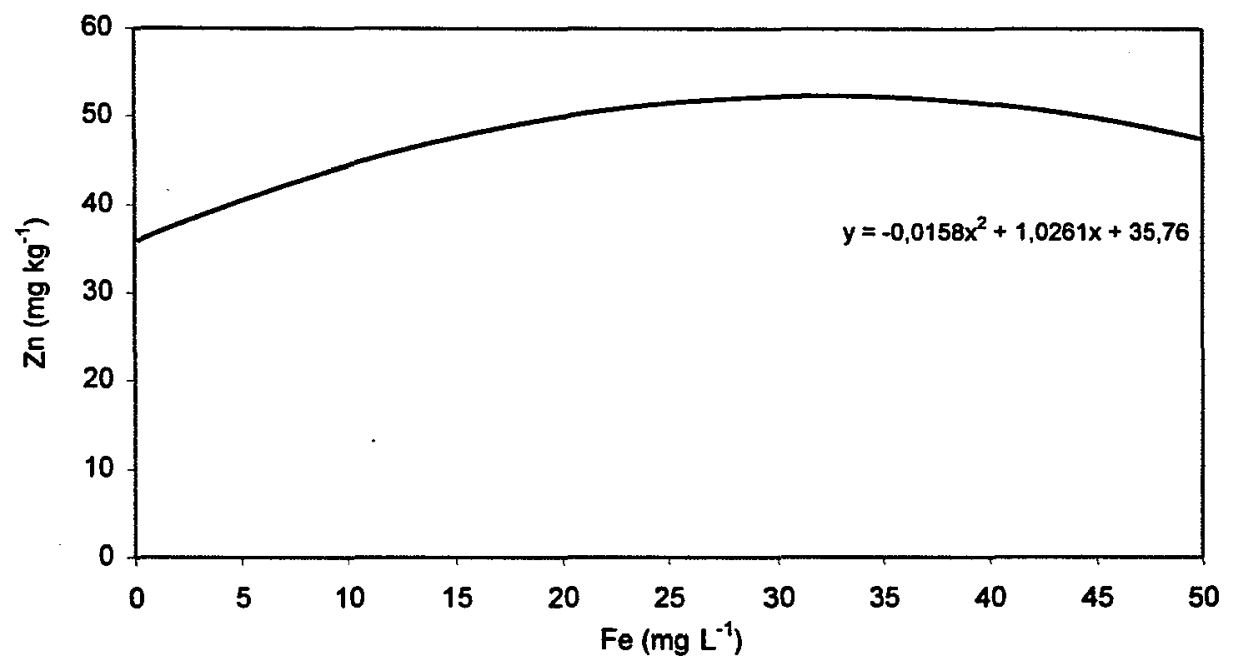

Figura 23. Relação entre concentração de zinco na matéria seca das raizes de dois genótipos de arroz, e doses de Fe na solução. 
Segundo Giordano et al. (1974), encontraram que em plântulas de arroz existe um efeito competitivo pelo mesmo sítio do carregador entre ferro e zinco, retardando a absorção de zinco pelas raízes, isto podería explicar a redução na concentração de zinco, nas doses mais elevadas de ferro na solução nutritiva.

4.6. Efeito dos níveis de ferro estudados, sobre o $\mathrm{pH}$ da solução nutritiva

A Tabela 31 mostra as variações de $\mathrm{pH}$ nas diferentes soluções nutritivas contendo níveis de ferro, em função do tempo (leitura a cada dois dias, com ajuste do mesmo na renovação a cada 7 dias) para cada genótipo em estudo. Observa-se que o $\mathrm{pH}$ diminuiu na primeira leitura, para posteriormente aumentar em função do tempo, semelhante ao obtido por Yunusa (1980), estudando o micronutriente ferro em plantas de sorgo, cultivado em solução nutritiva.

A variação mencionada podería ser principalmente devido a absorção diferencial das formas de nitrogênio pelas plantas de arroz, pelo que uma mais rápida absorção de $\mathrm{NH}_{4}{ }^{+}$diminuiría o $\mathrm{pH}$ da solução nos primeiros dias, e posteriormente maior absorção de $\mathrm{NO}_{3}^{-}$que provocaría elevação do mesmo, confirmando informações de Yoshida et al (1972), semelhante aos resultados encontrados por Yunusa (1980), utilizando como fonte de nitrogênio uma combinação de $\mathrm{NO}_{3}^{-}-\mathrm{NH}_{4}^{+}$de 8:1, relação que neste experimento foi de 7:1. Segundo Jacobson et al. (1956), quando excessiva quantidade de ânions são absorvidas pelas plantas, eles liberam íons $\mathrm{OH}^{\circ}$, provocando incremento do $\mathrm{pH}$. Contrariamente, quando cátions são absorvidos em excesso, íons $\mathrm{H}^{+}$são 
eliminados pelas raizes das plantas de arroz para a solução, originando diminuição no valor de pH. Bacha (1976) pesquisando ferro e manganês em solução nutritiva com plantas de arroz, encontrou variações de $\mathrm{pH}$ entre 4,8 para 7,6 na solução nutritiva, que devem ser esperadas em condições normais de cultivo.

É possível observar que o $\mathrm{pH}$ da solução no IAC-1205 foi mais estável, conforme aumentava o ferro na solução, assim no IAC-47 os valores de $\mathrm{pH}$ começaram a diminuir a partir da dose $0,125 \mathrm{mg} \mathrm{L}^{-1}$, ocassionando provavelmente maior disponibilidade de ferro na solução pela redução de $\mathrm{Fe}^{3+}$ para $\mathrm{Fe}^{2+}$. Segundo Rediske \& Biddulph (1953), a absorção de ferro de uma solução nutritiva está fortemente influenciada por mudanças no $\mathrm{pH}$, excercida provavelmente por aumento na mobilidade e absorção de nutrientes na superfície das raízes a valores de $\mathrm{pH}$ baixo. Ponnamperuma (1964), reportou que um $\mathrm{pH}$ de 6,5 - -7,5 reduz a concentração de ferro na solução nutritiva, ressaltando que ferro ferroso é altamente sensível a variações de $\mathrm{pH}$. 
Tabela 31. Variações de pH nas soluções nutritivas conforme os níveis de ferro, para dois genótipos de arroz, em função da idade das plantas dos genótipos.

\begin{tabular}{|c|c|c|c|c|c|c|c|c|c|}
\hline \multirow{2}{*}{$\begin{array}{c}\mathrm{Fe} \\
\left(\mathrm{mg} \mathrm{L}^{-1}\right)\end{array}$} & \multicolumn{8}{|c|}{ Idade das plantas* (dias) } & \multirow[b]{2}{*}{ Média } \\
\hline & 2 & 5 & 9 & 12 & 16 & 19 & 23 & 26 & \\
\hline & \multicolumn{8}{|c|}{ IAC- 47} & \multirow[b]{2}{*}{5,88} \\
\hline 0,125 & 3,43 & 7,18 & 5,04 & 7,56 & 5,13 & 7,36 & 5,08 & 6,64 & \\
\hline 0,625 & 3,44 & 7,15 & 4,99 & 7,45 & 5,07 & 7,58 & 4,99 & 6,68 & 5,95 \\
\hline 1,250 & 3,52 & 6,33 & 3,95 & 7,20 & 3,85 & 7,03 & 4,11 & 7,19 & 5,36 \\
\hline 12,50 & 3,59 & 5,68 & 4,03 & 6,65 & 4,19 & 6,68 & 4,56 & 6,55 & 5,19 \\
\hline 25,00 & 3,50 & 6,26 & 3,53 & 6,74 & 3,98 & 6,06 & 4,54 & 5,70 & 4,94 \\
\hline 50,00 & 4,02 & 4,69 & 3,67 & 4,86 & 3,87 & 5,19 & 4,81 & 5,46 & 4,66 \\
\hline Média & 3,58 & 6,21 & 4,20 & 6,74 & 4,35 & 6,65 & 4,68 & 6,37 & \\
\hline \multicolumn{10}{|c|}{ IAC- 1205} \\
\hline 0,125 & 3,58 & 4,24 & 3,43 & 6,97 & 3,58 & 6,93 & 4,02 & 6,55 & 4,85 \\
\hline 0,625 & 3,75 & 4,52 & 3,42 & 6,95 & 3,90 & 7,52 & 4,67 & 7,01 & 5,05 \\
\hline 1,250 & 3,63 & 5,05 & 3,51 & 6,94 & 3,94 & 7,18 & 4,82 & 7,31 & 5,15 \\
\hline 12,50 & 3,57 & 4,96 & 3,52 & 6,16 & 4,78 & 6,34 & 5,20 & 6,10 & 4,98 \\
\hline 25,00 & 3,61 & 4,38 & 3,36 & 6,44 & 3,51 & 7,02 & 4,34 & 6,76 & 4,83 \\
\hline 50,00 & 4,07 & 4,36 & 3,40 & 5,79 & 3,60 & 7,00 & 5,08 & 6,94 & 4,93 \\
\hline Média & 3,70 & 4,59 & 3,44 & 6,54 & 3,88 & 7,00 & 4,68 & 6,78 & \\
\hline
\end{tabular}

OBS: Datas das trocas da solução nutritiva: 19/07; 26/07; 02/08; 09/08.

* Idade das plantas, considerando a partir da solução nutritiva completa. 

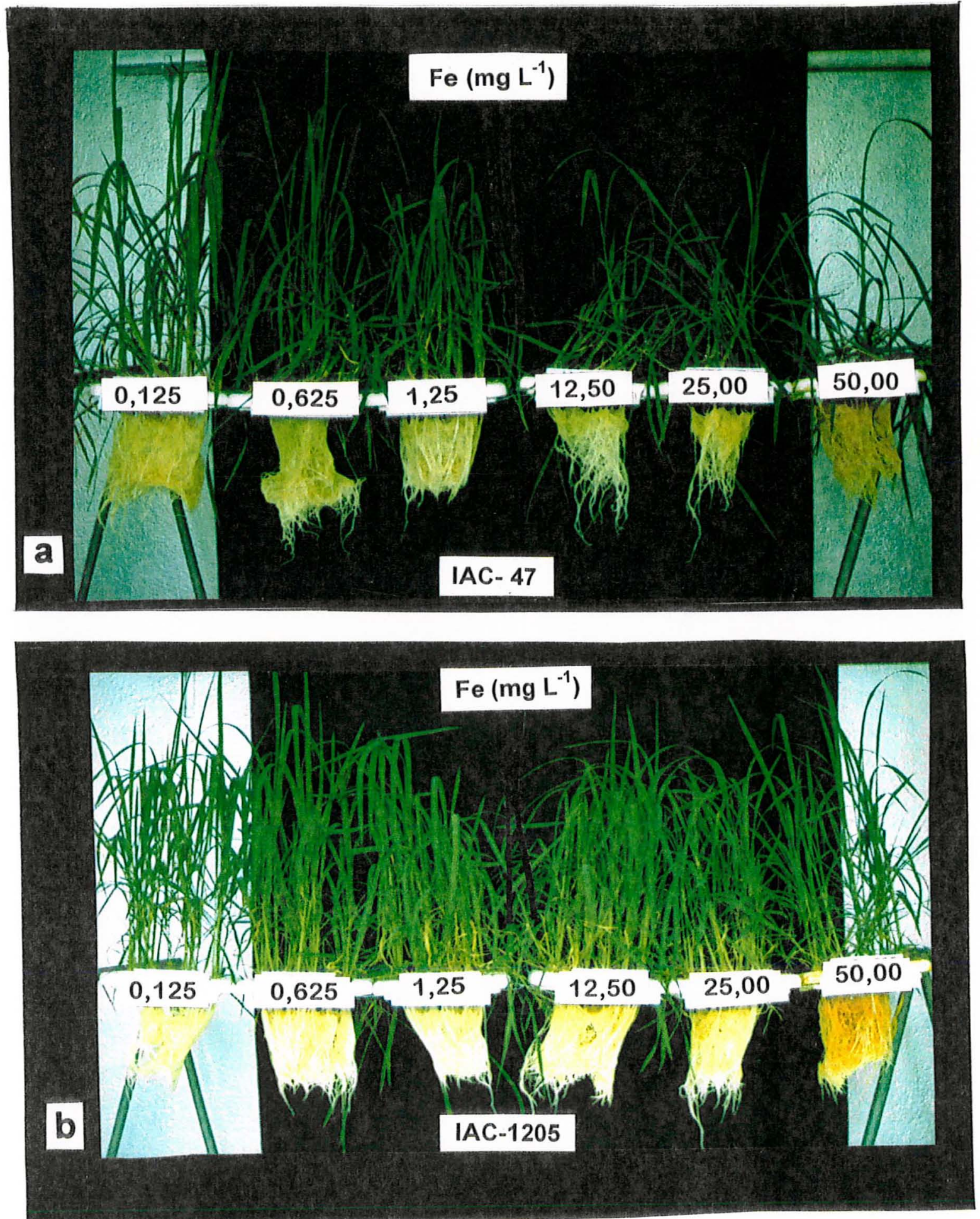

Figura 24. Aspecto da parte aérea e raízes de dois genótipos de arroz, conforme os níveis de Fe em solução nutritiva. a) IAC-47; b) IAC-1205. 

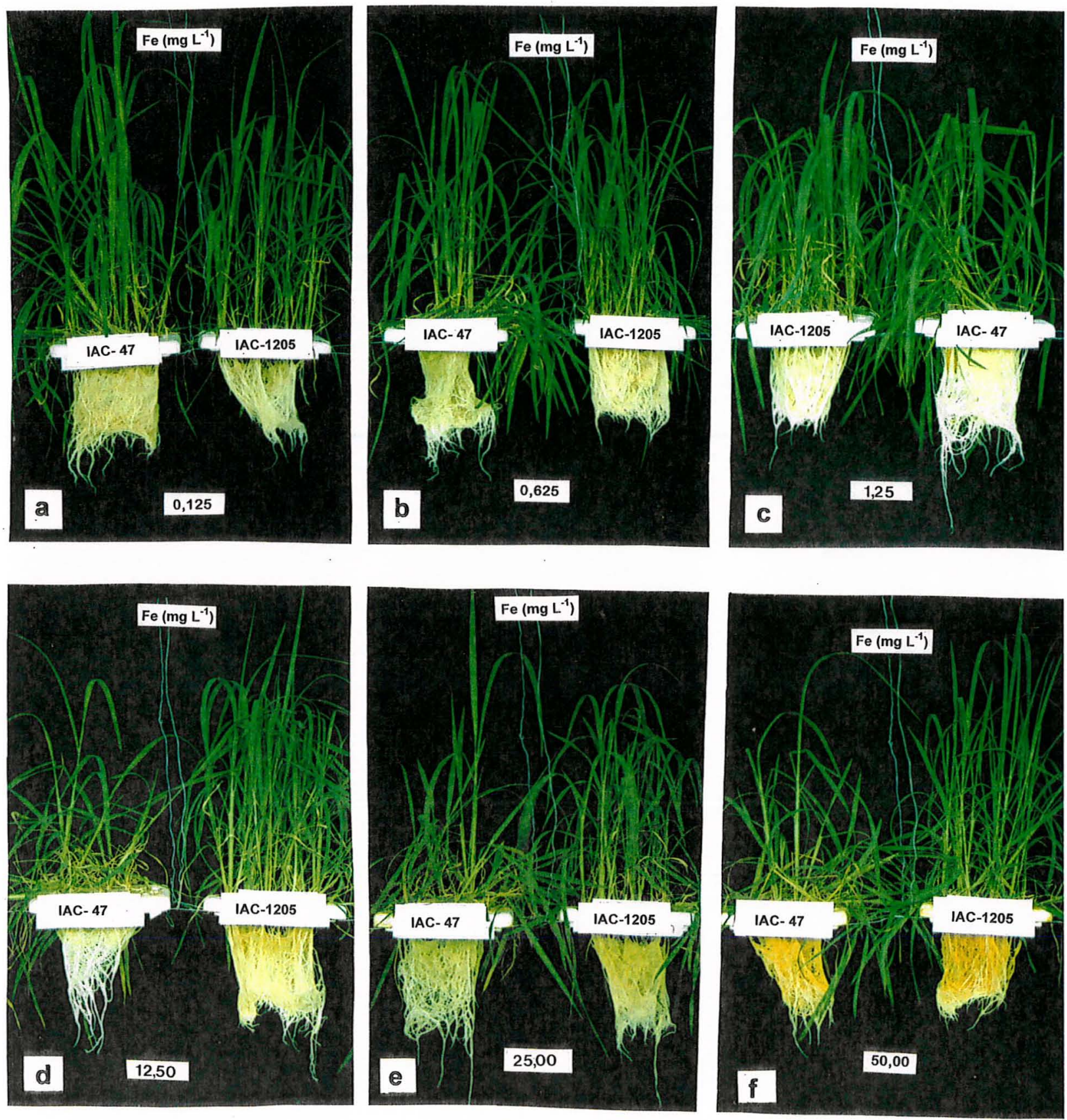

Figura 25. Dois genótipos de arroz, em função dos níveis de Fe em solução nutritiva $\left(\mathrm{mg} \mathrm{L}^{-1}\right)$. a) $\mathrm{Fe}-0,125$; b) Fe-0,625; c) Fe-1,25; d) Fe-12,50; e) Fe-25,0; e f) Fe-50,0. 


\section{CONCLUSÕES}

Os resultados obtidos nas condições em que foi desenvolvido o presente trabalho permitiram concluir que:

- A produção de matéria seca da parte aérea e das raízes das plantas de arroz foram reduzidas, nas concentrações de ferro na solução nutritiva de 25,0 e 50,0 $\mathrm{mg} \mathrm{L}^{-1}$.

- Altas doses de ferro na solução nutritiva afetaram a altura de planta, o comprimento de raiz, o número de perfilhos e a aérea foliar, das plantas de arroz.

- O genótipo IAC-1205 apresentou maior peso da matéria seca das raizes, área foliar, altura de planta, comprimento de raiz e número de perfilhos, em relação ao IAC-47, em doses maiores a $25 \mathrm{mg} \mathrm{L}^{-1}$ de ferro na solução nutritiva. Mostrando que o IAC-1205 foi mais tolerante às doses elevadas de ferro na solução, provavelmente devido a uma menor absorção e translocação de ferro das soluções, apresentando menores concentrações deste elemento na matéria seca da parte aérea e das raízes. 
- As doses de ferro em solução nutritiva a partir de $12,50 \mathrm{mg} \mathrm{L}^{-1}$ foram prejudiciais para o desenvolvimento dos genótipos, tendo sido mais acentuado no genótipo IAC-47.

- As concentrações de ferro aumentaram na matéria seca da parte aérea e das raízes nos dois genótipos em função do aumento dos níveis desse elemento na solução nutritiva, apresentando o IAC-47 maiores concentrações de ferro na matéria seca da parte aérea e das raízes.

- O incremento de ferro na solução, provocou aumento no teor de clorofila nas folhas dos dois genótipos.

- Doses elevadas de ferro $\left(25,0\right.$ e $\left.50,0 \mathrm{mg} \mathrm{L}^{-1}\right)$ na solução nutritiva, provocaram diminuição nas concentrações dos nutrientes analisados na matéria seca da parte aérea e raízes.

- A menor dose de ferro $0,125 \mathrm{mg} \mathrm{L}^{-1}$ em solução nutritiva, provavelmente não foi suficiente para diferenciar os dois genótipos, embora o IAC-1205 tenha apresentado sintomas mais acentuados de deficiência de ferro na parte aérea. 


\section{REFERÊNCIAS BIBLIOGRÁFICAS}

AGARWALA, S.C.; SHARMA, S.P.; FAROOQ, S. Effect of iron supply on growth, chlorophyll, tissue iron, and activity of certain enzymes in maize and radish. Plant Physiology, v.40, p. 494-9, 1965.

ALAM, S. M. Nutrient uptake by plants under stress conditions. In: PESSARAKLI, M., ed. Handbook of plant crop stress. New York: Marcel Dekker, 1994. cap. 10, p. 227-46.

ALLAN, D.L.; SHANN, J.R.; BERTSCH, P.M. Role of root cell walls in iron deficiency of soybean (Glycine max) and aluminum toxicity of wheat (Triticum aestivum). In: VAN BEUSICHEM, M.L., ed. Plant nutrition: physiology and applications. Dordrecht: Kluwer Academic Publishers, 1990. p. 345-9. 
ALLOUSH, G.A.; SANDERS, F.E. Responses of chickpea (Cicer arietinum) to iron stress measured using a computer - controlled continuous flow hydroponic system. In: VAN BEUSICHEM, M.L., ed. Plant nutrition: physiology and application. Dordrecht: Kluwer Academic Publishers, 1990. p. 197-206, 1990.

ANUÁRIO ESTATÍSTICO DO BRASIL - 1993, Rio de Janeiro, v.53 p.3.28$3.35,1993$.

AYED, I.A. A study of the mobilization of iron in tomato roots by chelate trataments. Plant and Soil, v. 32, p. 18-26, 1970.

BACHA, R.E. Effects of iron and manganese in culture solution on their concentrations in roots and shoots of rice plants (Oryza sativa L.) grown under anaerobic conditions. Texas, 1976. 91p. Thesis (MS) - Texas A\&M University.

BACHA, R.E. Avaliação de linhagens e cultivares de arroz irrigado para condições adversas de solo: toxidez por ferro. In: REUNIÃO DA CULTURA DO ARROZ IRRIGADO, Camboriú, 1991. Trabalhos apresentados. Florianópolis: EMPASC, 1991. p. 377-83.

BACHA, R.E.; HOSSNER, L.R. Characteristics of coatings formed on rice roots as affected by iron and manganese additions. Soil Science Society of America Journal, v.41, n.5, p.931-5, 1977. 
BACHA, R.E.; ISHIY, T. Seleção de genótipos de arroz irrigado para resistência à toxicidez de ferro. In: REUNIÃO DA CULTURA DO ARROZ IRRIGADO. Camboriú, 1987. Trabalhos apresentados. Florianópolis: EMPASC, 1987. p. 85-91.

BHAN, K.C.; WALLACE, A.; KROHN, E.J. Effect of $\mathrm{pH}$ and nitrogen source on the ability of corn and soybean to obtain iron chelated with ethylenediamine di (o-hydroxiphenylacetate). Agronomy Journal, v., p. 119-21, Jan./Feb. 1962.

BANZATTO, N.V.; AZZINI, L.E.; SOAVE, J.; DE SOUZA, D.M.; DA ROCHA, T.R.; ALOISI SOBRINHO, J. IAC-47 - novo cultivar de arroz de sequeiro. Campinas: Instituto Agronômico, 1978. 9p. (IAC. Circular, 99).

BAR-AKIVA, A.; LAVON, R. Peroxidase activity as an indicator of iron requeriment of citrus plant. Israel Journal of Agricultural Research, v. 18, p. 145-53, 1968.

BARBOSA FILHO, M.P. Nutrição e adubação do arroz (sequeiro e irrigado). Piracicaba: Associação Brasileira para Pesquisa da Potassa e do Fosfato, 1987. 120 p. (Boletim técnico, 9).

BARBOSA FILHO, M.P.; FAGERIA, N.K.; STONE, L.F. Manejo d' água e calagem em relação à produtividade e toxicidade de ferro em arroz. Pesquisa Agropecuária Brasileira, v.18, n.8, p. 903-10, ago. 1983. 
BATAGLIA, O.C. Micronutrientes no solo - ferro. In: FERREIRA, M.E.; DA CRUZ, M.C.P. ed. Micronutrientes na agricultura. Piracicaba: Associação Brasileira para Pesquisa da Potassa e do Fosfato/CNPq., 1991. p. 159-71.

BENCKISER, G.; OTTOW, J.C.G.; WATANABE, I.; SANTIAGO, S. The mechanism of excessive iron-uptake (iron toxicity) of wetland rice. Journal of Plant Nutrition, v.7, n.1/5, p. 177-85, 1984.

BENCKISER, G.; SANTIAGO, S.; NEUE, H.U.; WATANABE, I.; OTOW, J.C.G. Effect of fertilization on exudation, dehydrogenase activity, ironreducing populations and $\mathrm{Fe}^{++}$formation in the rhizosphere of rice (Oriza sativa L.) in relation to iron toxicity. Plant and Soil, v.79, n.3, p. 305-16, 1984.

BERGMANN, W., ed. Nutritional disorders of plants: development, visual and analytical diagnosis. Stuttgart: Gustav Fischer, 1992. 741p.

BROWN, J.C.; JONES, W.E. Fitting plants nutritionally to soils. I. Soybeans. Agronomy Journal, v.69, p. 399-404, May/June 1977.

BURSTROM, H.G. Calcium and plant growth. Biology Review, v.43, p. 287$316,1968$.

CLARKSON, D.T.; SANDERSON, J. Sites of absortion and translocation of iron in barley roots. Plant Physiology, v.61, p.731-6, 1978. 
CAMARGO, C.E.O. Tolerância de cultivares de arroz em estádio de plântula a diferentes níveis de ferro em solução nutritiva. Bragantia, v.43, n.2, p.369-80, 1984.

CAMARGO, C.E.O.; CAMARGO, O.B.A. Estudo comparativo da tolerância à toxicidade de ferro e alumínio em arroz. Bragantia, v.44, n.1, p. 97-114, 1985.

CAMARGO, C.E.O.; FREITAS, J.G. Tolerância de cultivares de trigo a diferentes níveis de ferro em solução nutritiva. Bragantia, v.44, n.1, p. 65-75, 1985.

CAMARGO, C.E.O.; FELÍCIO, J.C.; FREITAS, J.G.; FERREIRA FILHO, A.W.P. Tolerância de trigo, triticale e centeio a diferentes níveis de ferro em solução nutritiva. Bragantia, v.47, n.2, p. 295-304, 1988.

CHEN, C.C.; DIXON, J.B.; TURNER, F.T. Iron coatings on rice roots: Mineralogy and quantity influencing factors. Soil Science Society of America Journal, v.44, n.3, p. 635-9, 1980.

CLARKSON, D.T.; SANDERSON, J. Sities of absorption and translocation of iron in barley roots. Tracer and microautoradiographic studies. Plant Physiology, v.61, p. 731-6, 1978. 
DUARTE, A.P.; VOLTAN, R.B.Q.; FURLANI, P.R. Amarelecimento do arroz de sequeiro sob condições de encharcamento em solo de baixa fertilidade. Bragantia, v.52, n.2, p. 139-52, 1993.

EGMOND, F. van; AKTAS, M. Iron nutritional aspects of the ionic balance of plants. Plant and Soil, v.48, p. 685-703, 1977.

FAGERIA, N.K. Solos tropicais e aspectos fisiológicos das culturas. Goiânia: EMBRAPA, CNPF, 1989. cap.9, p. 197-253: Variabilidade genética das plantas em relação à nutrição mineral.

FAGERIA, N.K. Iron requirement of cereals and legumes in solution culture. In: VAN BEUSICHEM, M.L. van, ed. Plant nutrition: physiology and applications, p. 213-7, 1990.

FAGERIA, N.K.; KLUTHCOUSKI, J. Metodologia para avaliação das cultivares de arroz e feijão, para condições adversas de solo. Goiânia: EMBRAPA, CNPAF, 1980. 22p. (EMBRAPA/CNPAF. Circular Técnica, 8).

FAGERIA, N.K.; RABELO, N.A. Tolerance of rice cultivars to iron toxicity. Journal of Plant Nutrition, v.10, n.6, p. 653-61, 1987.

FAGERIA, N.K.; BALIGAR, V.C.; WRIGHT, R.J. Iron nutrition of plants: an overview on the chemistry and physiology of its deficiency and toxicity. Pesquisa Agropecuária Brasileira, v.25, n.4, p. 553-70, Apr. 1990. 
FAGERIA, N.K.; BARBOSA FILHO, M.P.; CARVALHO, J.R.P. de. Influência do ferro no crescimento e na absorção de $\mathrm{P}, \mathrm{K}, \mathrm{Ca}$ e $\mathrm{Mg}$ pela planta do arroz em solução nutritiva. Pesquisa Agropecuária Brasileira, v.16, n.4, p. 483-8, July/Ago. 1981.

FAGERIA, N.K.; GUIMARÃES, C.M.; PORTES, T. de A. Deficiência de ferro em arroz de sequeiro. Lavoura Arrozeira, v.47, n.416, p. 3-5, set./out. 1994.

FAGERIA, N.K.; BARBOSA FILHO, M.P.; CARVALHO, J.R.P.; RANGEL, P.H.N.; CUTRIM, V.D.A. Avaliação preliminar de cultivares de arroz para tolerância à toxidez de ferro. Pesquisa Agropecuária Brasileira, Brasília, v.19, n.10, p. 1271-8, out. 1984 .

FAGERIA, N.K.; FERREIRA, E.; PRABU, A.S.; BARBOSA FILHO, M.P.; FELIPPI, M.C. Seja o doutor do seu arroz. Piracicaba: POTAFOS, 1995. 20p. (Arquivo do Agrônomo, 9).

FAO QUATERLY BULLETIN OF STATISTICS - 1994, Rome, v.7, p. 21, 1994.

FOY, C.D.; CHANEY, R.L.; WHITE, M.C. The Physiology of metal toxicity in plants. Annual Review of Plant Physiology, v.29, p. 511-66, 1978.

FURLANI, A.M.C.; FURLANI, P.R. Composição e pH de soluções nutritivas para estudos físiológicos e seleção de plantas em condições nutricionais adversas. Campinas: IAC, 1988. 34p. (IAC. Boletím Técnico, 121). 
FURLANI, P.R.; FURLANI, A.M.C. Tolerância a alumínio e eficiência a fósforo em milho e arroz: Características independentes. Bragantia, Campinas, v.50 n.2, p. 331-40, 1991.

FURLANI, P.R.; HANNA, L.G. Avaliação da tolerância de plantas de arroz e milho ao alumínio em solução nutritiva. Revista Brasileira da Ciência do Solo, v.8, n.2, p. 205-8, maio/ago. 1984.

GENON, J.N.; HEPCEE, N de; DUFFY, J.E.; DELVAUX, B.; HENNEBERT, P.A. Iron toxicity and other chemical soil constraints to rice in higland swamps of Burundi. Plant and Soil, v.166, p. 109-15, 1994.

GIORDANO, P.M.; NOGGLE, J.C.; MORTVEDT, J.J. Zinc uptake by rice as affected by metabolic inhibitors and competing cations. Plant and Soil, v.41, p. 637-46, 1974.

HOLMES, R.S. Effect of phosphorus and $\mathrm{pH}$ on iron chlorosis of the blueberry in water culture. Soil Science, v.90, p. 374-9, 1960.

HOWELER, R.H. Iron-induced oranging disease of rice in relation to physicochemical changes in a flooded oxisol. Soil Science Society of America Proceedings, v.37. p. 898-903, 1973.

INSTITUTO AGRONÔMICO DE CAMPINAS. Agulhinha de sequeiro IAC201: cultivar de arroz para o Estado de São Paulo - 1992. Campinas, 1992. n.p. 
INTERNATIONAL RICE RESEARCH INSTITUTE. Annual report for 1970. Los Baños, 1971. p. 39-41: Micronutrientes uptake by rice.

INTERNATIONAL RICE RESEARCH INSTITUTE. Annual report for 1971. Los Baños, 1972. p. 40-1: Iron toxicity.

ISHIZUKA , Y. Effect of iron, manganese and cooper level of solution on yields and chemical composition of plant. Journal Science Soil Manure, v.32, p. 97$100,1961$.

JACOBSON, L.; OERTLI, J.J. The relation between iron and chlorophyll contents in clorotic sunflower leaves. Plant Physiology, v.31, p. 199-204, 1956.

JENSEN, C.R.; STOLZY, L.H.; LETEY, J. Tracer studies of oxygen diffusion through root of barley, corn and rice. Soil Science, v.103, p.23-9, 1967.

JONES Jr, B.J. ; BENJAMIN WOLF; MILLS, H.A. Plant analysis handbook. Athens: Micro-Macro Pub., 1991. 213 p.

JUGSUJINDA, A.; PATRICK Jr, W.H. Evaluation of toxic conditions associzted with oranging symptoms of rice in a flooded oxisol in Sumatra, Indonesia. Plant and Soil, v.152, p. 237-43, 1993. 
KAMPFENKEL, K.; VAN MONTAGU, M.; INZÉ, D. Effects of iron excess on Nicotiana plumbaginifolia plants - Implications to oxidative stress. Plant Physiology, v.107, p. 725-35, 1995.

KIRK, G.J.D.; BEGG, C.B.M.; SOLIVAS, J.L. The chemistry of the lowland rice rhizosphere. Plant and Soil, v.155/156, p. 83-6, 1993.

LAHAR, N.; ZIPORI, I. Fixação of iron applied as Fe-EDTA: Effect of calcium concentration and soil solid phase. Soil Science American Journal, v.42, p. 255-7, 1978.

LANDSBERG, E.Ch. Organic acid synthesis and release of hydrogen ions in response to $\mathrm{Fe}$ deficiency stress of mono and dicotyledonous plant species. Journal Plant Nutrition, v.3, p. 579-91, 1981.

LINDSAY, W.L. Role of chelation in micronutrients availability. In: CARLSON, E.W., ed. The plant root and its environment. Charlottesville: University Press of Virginia, 1974. p. 507-24.

LINDSAY, W.L.; SCHWAB, A.P. The chemistry of iron in soil and its availability to plants. Journal of Plant Nutrition, v.5, n.4/7, p. 821-40, 1982.

LINHEMAN, D.J. micronutrient cation sorption by roots and uptake by plants. Journal Experimental Botany, v.35, p.1571-4, 1984.

LONGNECKER, N.; WELCH, R. The relationships among iron-stress response, iron-uptake of plants. Journal of Plant Nutrition, v.9, p. 715-27, 1986. 
LOPES, M.S. Efeito da adubação e da calagem sobre a produtividade e a toxidez de ferro na cultivar BR-IRGA 409. In: REUNIÃO DA CULTURA DO ARROZ IRRIGADO, 16., Camboriú, 1987. Trabalhos apresentados. Florianópolis: EMPASC, 1987. p.187-93.

MACHOLD, O.; STEPHAN, U.W. The function of iron in porphyrin and chlorophyll byosinthese. Phytochemistry, v.8, p. 2189-92, 1969.

MALAVOLTA, E. Nutrição mineral e adubação do arroz irrigado. São Paulo: Ultrafértil, 1978. 64p.

MALAVOLTA, E. Nutrição mineral e adubação do arroz de sequeiro. 2.ed. São Paulo: Ultrafértil, 1979. 40p.

MALAVOLTA, E. Nutrição mineral. In: FERRI, M.G. Fisiologia vegetal 1. 2. ed. São Paulo: EPU, 1985. cap. 2, p. 97-116.

MALAVOLTA, E.; FORNASIERI FILHO D. Nutrição mineral da cultura do arroz. In: FERREIRA, M.E.; YAMADA T.; MALAVOLTA, E., ed. Cultura do arroz de sequeiro: fatores afetando a produtividade; anais. Piracicaba: Instituto da Potassa e Fosfato, 1983. p. 95-140.

MARSH Jr., H.V.; EVANS, H.J.; MATRONE, N. Investigations of the role of iron in chlorophyll metabolism. I. Effect of iron deficiency on chlorophyll and heme content and on the activities of certain enzymes in leaves. Plant Physiology, v.38, p. 632-7, 1963. 
MARSCHNER, H. Mineral nutrition of higher plants. Orlando: Academic Press, 1986. $674 \mathrm{p}$.

MARSCHNER, H.; ROMHELD, V. Strategies of plants for acquisition of iron. Plant and Soil, v.165, n.2, p. 261-74, 1994.

MELO BASTOS, F.J. de. Efeito do ferro, gesso agrícola e calcário na produção de arroz (Oryza sativa L.) em solos de várzea inundados. Lavras, 1993. 90p. Dissertação (MS.) - Escola Superior de Agricultura de Lavras.

MENGEL, C.; KIRKBY, E.A. Principles of plant nutrition. 4.ed. Worblaufen-Bern: International Potash Institute, 1987. 687p.

MINOLTA CAMERA Co. Manual for chlorophyll meter SPAD-502. Osaka: Minolta Camera Co., 1989. 22p.

MOORE Jr., P.A.; PATRICK Jr., W.H. Iron availability and uptake by rice in acid sulfate soil. Soil Science Society of America Journal, v.53, p. 471-6, 1989.

MOORE Jr., P.A.; ATTANANDANA, T.; PATRICK Jr., W.H. Factors affecting rice growth on acid sulfate soils. Soil Science Society of America Journal, v.54, p. 1651-6, 1990. 
NISHIZONO, H.; ICHIFAWA, H.; SUZIKI, S.; ISHII, F. The role of the root cell wall in the heavy metal tolerance of Athyrium yokoscense. Plant and Soil, v.101, p. 15-20, 1987.

OADES, J.M. The nature and distribution of iron compound in soil. Soils and Fertilizers, v.26, p. 69-80, 1963.

OBATA, H. 1. Physiological functions of micro essential elements. In: MATSUO, T; KUMASAWA, K.; ISHII, R.; ISHIHARA, K.; HIRATA, H., ed. Science of the rice plant: physiology. Tokyo: Food and Agriculture Policy Research Center, 1995. v.2, cap. 4, p. 402-11.

O'CONNOR, G.A.; LINDSAY, W.L.; OLSEN, S.R. Iron diffusion to plant roots. Soil Science, v.119, n.4, p. 285-9, 1975.

OKUDA, A.; TAKAHASHI, E. The role of silicon. In: SYMPOSIUM ON THE MINERAL NUTRITION OF THE RICE PLANT, 4., Baltimore, 1964. Proceedings. Baltimore: The Johns Hopkings Press, 1965. p. 63-146.

O' SULLIVAN, M. Iron metabolism of grasses. I. Effect of iron supply on some inorganic and organic constituents. Plant and Soil, v.31, n.3, p. 451-62, 1969.

OTTE, M.L.; ROZEMAL, L.; KOSTER, L.; HAARSMA, M.S., BROEKMAN, R.A. Iron plaque on roots of Aster trifolium. Interaction with zinc uptake. New Phytopatology, v.111, p. 309-17, 1989. 
OTTOW, J.C.G.; BENCKISER, G.; WATANABE, I. Is iron toxicity of rice the result of a multiple nutritional stress?. Plant Research and Development, Tubingen, v.17, p. 96-109, 1983.

OTTOW, J.C.G.; BENCKISER, G.; WATANABE, I.; SANTIAGO S. Multiple nutritional soil stress as the prerequisite for iron toxicity of wetland rice (Oryza sativa L.). Tropical Agriculture, v.60, n.2, p. 102-6, 1983.

PATRA, B.N.; MOHANTY, S.K. Effect of nutrients and liming on changes in $\mathrm{pH}$, redox potencial, and uptake of iron and manganese by wetland rice in irontoxic soil. Biology and Fertility of Soils, v.17, n.4, p. 285-8, 1994.

PENG, S.; GARCÍA, P.F.; LAZA, R.C.; CASSMAN, K.G. Adjustment for specific leaf weight improves chlorophyll meter's estimate of rice leaf nitrogen concentration. Agronomy Journal, v.85, p. 987-90, 1993.

PINHEIRO, B.da S.; GUIMARÃES, E.P. Indice de área foliar e produtividade do arroz de sequeiro. I. Níveis limitantes. Pesquisa Agropecuária Brasileira, v.25, n.6, p. 863-72, jun. 1990 .

PINHEIRO, B.da S.; MARTINS, J.F.da S.; ZIMMERMANN, F.J. Indice de área foliar e produtividade do arroz de sequeiro. II. Manifestação através dos componentes da produção. Pesquisa Agropecuária Brasileira, Brasília, v.25, n.6, p. 873-9, jun. 1990. 
PONNAMPERUMA, F.N. Dynamic aspects of flooded soils and the nutrition of the rice plant. In: SYMPOSIUM ON THE MINERAL NUTRITION OF THE RICE PLANT, 4., Baltimore, 1964. Proceedings. Baltimore: The Johns Hopkings Press, 1965. p.295-321.

PONNAMPERUMA, F.N.; BRADFIELD, R.; PEECH, M. Physiological disease of rice attributable to iron toxicity. Nature, London, v.175, p. 265, Feb. 1955.

PUSHNIK, J.C.; MILLER, G.W.; MANWARING, J.H. The role of iron in higher plant chlorophyll biosynthesis, maintenance, chloroplast biogenesis. Journal of Plant Nutrition, v.7, n.1-5, p. 733-58, 1984,

RAALTE, M.H. van On the oxygen supply of rice roots. Annual Botany Gardens Buitenzorg, v.51, p. 43-7, 1941.

REDISKE, J.H.; BIDDULPH, O. The absortion and translocation of iron. Plant Physiology, v.28, n.1, p. 576-93, Jan. 1953.

SALARDINI, A.A.; MURPHY, L.S. Grain sorghum (Sorghum bicolor Pers) responses to organic iron on calcareus soils. Plant and Soil, v.49, p. 57-70, 1978.

SALISBURY, F.B.; ROSS, C.W. Plant physiology. 4.ed. Belmont: Wadsworth Pub., Division of Wadsworth, 1992. 682p. 
SARRUGE, J.R.; HAAG, H.P. Análises químicas em plantas. Piracicaba: ESALQ, 1974. 56p.

SHETTY, A.S.; MILLER, G.W. Influence of iron chlorosis on pigments and protein metabolism in leaves of Nicotiana tabacum L., Plant Physiology, v.41, p. 415-21, 1966.

SHIMADA, N. Deficiency and excess of micronutrient elements. In: MATSUO, T; KUMASAWA, K.; ISHII, R.; ISHIHARA, K.; HIRATA, H., ed. Science of the rice plant: physiology. Tokyo: Food and Agriculture Policy Research Center, 1995. v.2, cap. 4, p. 412-7.

SHUMAN, L.M. Mineral nutrition. In: WILKINSON, R.E., ed. Plant environment interactions. New York: Marcel Dekker, 1994. cap 5, p. 14982.

SIDERIS, C.P.; YOUNG, H.Y. Pineapple chlorosis in relation to iron and nitrogen. Plant Physiology, v.31, p. 211-21, 1956.

SINGH, R.; SINHA, M. K. Reactions of iron chelates in calcareus soil and their relative efficiency in iron nutrition on corn. Plant and Soil, v.46, p. 17-29, 1977.

SPILLER, S.; TERRY, N. Limiting factors in photosynthesis II. Iron stress dimishes photochemical capacity by reduzing the number of photosynthetic units. Plant Physiology, v.65, p. 121-5, 1980. 
TADANO, T. Devices of rice roots to tolerate high iron concentration in growth media. JARQ, v.9, n.1, p. 34-9, Jan. 1975.

TAIZ, L.; ZEIGER, E. Plant physiology. Redwood City, California. The Benjamin/Cumming Publ., 1991. cap.5, p. 100-19: Mineral nutrition.

TANAKA, A.; NAVASERO, S.A. Interaction between iron and manganese in the rice plant. Soil Science Plant Nutrition, v.12, p. 29-33, 1966.

TANAKA, A.; LOE, R.; NAVASERO, S.A. Some mechanism involved in the development of iron toxicity symptoms in the rice plant. Soil Science Plant Nutrition, v.12, p. 158-64, 1966.

TAKIJIMA, Y. Studies on the mechanisms of root damage of rice plants in the peat paddy fields. Status of roots in the rhizosphere and the ocurrence of root damage. Soil Science Plant Nutrition, v.11, p. 204-11, 1965.

TAYLOR, G.S. Exclusion of metals from the symplasm: A possible mechanism of metal tolerance in higher plants. Journal of Plant Nutrition, v.10, p. 1213-22, 1987.

TERRY, N. Limiting factors in photosynthesis I. Use of iron stress to control photochemical capacity in vivo. Plant Physiology, v.65, p. 114-20, 1980. 
TERRY, N.; ABADIA, J. Function of iron in chloroplast. Journal of Plant Nutrition, v.9, n.3/7, p. 609-46, 1986.

TERRY, N.; LOW, G. Leaf chlorophyl content and its relation to the intracellular localization of iron. Journal of Plant Nutrition, v.5, p. 301-10, 1982.

TERRY, N.; RAO, M. Iron supply and photosynthesis. In: PORTER, J.R.; LAWLOR, D.W., ed. Plant growth: interactions with nutrition and environment. Society for Experimental Biology, 1991. p. 56-63.

TISDALE, S.L.;NELSON, W.L.; BEATON, J.D. Iron. Soil fertility and fertilizers. 4.ed. London: Macmillan Pub., 1985. cap.9, p. 350-413: Micronutrients and other benefical elements in soils and fertilizers.

TROLLDENIER, G. Mineral nutrition and reduction processes in the rhizosphere of rice. Plant and Soil, v.47, p. 193-202, 1977.

USBERTI FILHO, J.A.; AZZINI, L.E.; TISSELLI FILHO, O.; SOAVE, J.; FURLANI, P.R.; GALLO, P.B.; PETTINELLI JÚNIOR, A.; CASTRO, J.L.; VITTI, P. Cultivar IAC-165 de arroz de sequeiro: comportamento agronômico, qualidades tecnológicas e culinarias. Campinas: Instituto Agronômico, 1987. 13p. (IAC. Boletim Técnico, 115). 
VIEIRA, A.R.R.; STEINMETZ, S.; BRUNINI, O. Parâmetros de crescimento de duas cultivares de arroz sob diferêntes regimes de água no solo. Pesquisa Agropecuária Brasileira, v.25, n.6, p. 897-904, jun. 1990.

VIRMANI, S.S. Varietal tolerance of rice to iron toxicity in Liberia. IRRI Newsletter, v.2, n.1, p. 4, 1977.

VORM, P.D.J.van der; DIEST, A.van. Aspects of the Fe and Mn nutrition of rice plants. II. Iron and manganese uptake by rice plants, growtn on aerobic water cultures. Plant and Soil, v.52, p. 19-29, 1979.

VOSE, P.B. Iron nutrition in plants: a world overview. Journal of Plant Nutrition, v.5, n.4/7, p. 233-49, 1982.

WANG, J.; LIAO, Z.; SHUMAN, L.M. Interaction of silicon, iron and manganese in rice (Oryza sativa L.) rhizosphere at low $\mathrm{pH}$ in relation to rice growth. Journal of Plant Nutrition, v.17, n.5, p. 775-85, 1994.

WELCH, R.M.; LARUE, T.A. Physiological characteristics of Fe accumulation in the 'Bronze' mutant of Pisum sativum L., cv 'Sparkle' E107 (brz brz). Plant Physiology, v.93, p.723-9, 1990.

WINSLOW, M.D.; YAMAUCHI, M.; ALLURI, K.; MASAJO, T.M. Reducing iron toxicity in rice with resistant genotype and ridge planting. Agronomy Journal, v.81, p. 458-60, 1989. 
YANG, X.; ROMHELD, V.; MARSHNER, H. Effect of bicarbonate and root temperature on uptake of $\mathrm{Zn}, \mathrm{Fe}, \mathrm{Mn}$ and $\mathrm{Cu}$ different rice cultivars (Oryza sativa L.) grown in calcareus soil. Plant and Soil, v.155/156, p. 441-4, 1993.

YOSHIDA, K; YAMAMURU, S. A nutritional disorders of rice plants observed in Brunei. JARQ., v.19, n.4, p. 311-4, Mar, 1986

YOSHIDA, S.; FORNO, D.A.; COCK J.H.; GOMEZ K.A. Laboratory manual for physiological studies of rice. 2.ed. Los Baños: The International Rice Research Institute, 1972. 69p.

YUNUSA, Y. Screening sorghum [Sorghum bicolor (L.) Moench] genotypes for differential responses to iron nutrition. Nebraska, 1980. 190 p. Thesis (Ph. D.) University of Nebraska.

ZAHARIEVA, T. Comparative studies of iron inefficient plant species with plant analysis. Journal of Plant Nutrition, v.9, n.3/7, p. 939-46, 1986. 